Department OF The INTERIOR

Roy O. West; Secretary

U. S. GEOLOGICAL SURVEY

George Otis Smith, Director

Bulletin 801

\author{
GEOLOGY AND WATER RESOURCES \\ OF THE \\ EDGELEY AND LA MOURE QUADRANGLES \\ NORTH DAKOTA
}

BY

HERBERT A. HARD

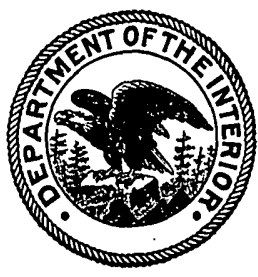

UNITED STATES

GOVERNMENT PRINTING OFFICE

WABHINGTON 
ADDITIONAL COPIES

OF THIS PUBLICATION MAY BE PROCURED FROM THE SUPERINTENDENT OF DOCUMENTS U.S.GOVERNMENT PRINTING OFFICE WASHINGTON, D. C.

$\Delta T$

50 CENTS PER COPY 


\section{CONTENTS}

Introduction . . . Page

Location and general relations............................. 1

General features of North Dakota......................... 2

Topography .......... 2

Drainage............ 3

Bedrock surface............ 4

Stratigraphy and structure.

Settlement of the quadrangles.

Topography . .

Relief

Lake and river plains.

Uplands . . . 7

Drainage....

James River

Bear Creek . . .

Maple River. . . 10

Elm River........ 11

Lakes _ .

Springs _...

Climate and vegetation 12

Descriptive geology

Cretaceous system.......... 13

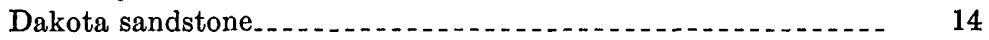

Depth and thickness........ 14

Character......... 14

Fossils

Colorado group.

Benton shale........ 15

Niobrara shale.....

Montana group 17

Pierre shale . .

Thickness. . .

Outcrop

Fossils..... 17

Quaternary system

Pleistocene series....

General glacial features.

Color and oxidation. 20

Age of the drift.

Leaching:-

Induration. 21

Glacial boulders . . 21

Configuration of the drift and of the bedrock ........ 22 
Descriptive geology-Continued.

Quaternary system-Continued.

Pleistocene series-Continued.

Wisconsin drift.

General features

Altamont and Gary morain

Till plain between the Gary and Altamont moraines..-

Antelope morainic system.........

Outer moraine.

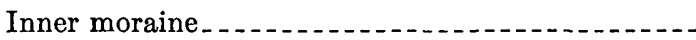

Till plain and eskers between the outer and inner moraines of the Antelope morainic system..........

Till plain east of the inner moraine of the Antelope morainic system

Correlation of the moraines.......

Oakes moraine......

Sand Prairie deposits.

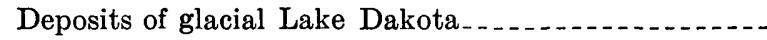

Terraces of James River. . .

Recent series.

Alluvium

Sand dunes....

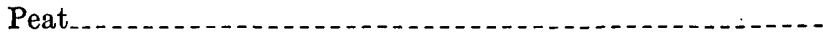

Geologic history

Cretaceous period.

Dakota epoch...

Tertiary period.

Post-Cretaceous erosion........

Preglacial drainage of the Dakotas

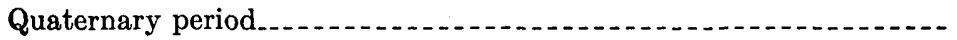

Pleistocene epoch

Glaciation....

Glacial Lake Dakota...

James River Valley.....

Economic geology .... 42

Building materials... 42

Sand and gravel

Brick clay and shale. 42

Soils............... 43

Water resources...... 44

Water in glacial drift. 44

Water in the Pierre and Benton formations........ 45

Water in the Dakota sandstone........ 47

Scope and methods of testing artesian wells

Position of water-bearing beds.... 49

Artesian conditions... 50

Types and yields of wells.... 50

Irregularities in head.

Original head...... 53

Decline in head and flow................ 54

Artesian conditions and prospects as shown by the 1923 survey, by O. E. Meinzer

History of artesian-well drilling in the Edgeley quadrangle_ $\quad 57$

Original head and area of artesian flow 
Economic geology-Continued.

Water resources-Continued.

Artesian conditions and prospects as shown by the 1923 survey, by $\mathrm{O}$. E. Meinzer-Continued.

Decline in head from 1886 to 1923

Shrinkage in the area of artesian flow

Increase in hydraulic gradient. . .

Correlation of decline in head with descent of artesian

boundary ...............

Yield of flowing wells and decline in yield. ............

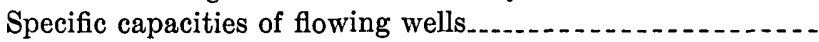

Total discharge of flowing wells.

Beneficial flow as estimated by the State Geological Survey - $\quad 66$

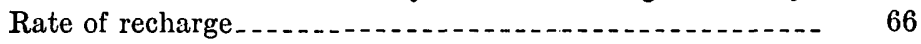

Withdrawal of stored water and compression of the Dakota

sandstone. . . . .

Beneficial effect of the conservation policy adopted by the

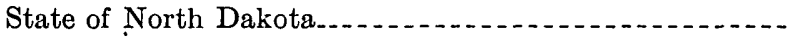

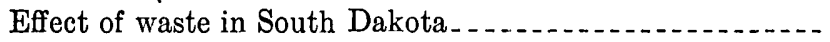

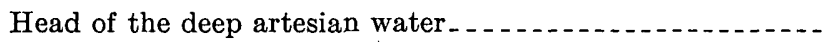

Quality of the water.

Temperature of the water

Natural gas

Data on artesian wells....... 78

Index.......... 89

\section{ILLUSTRATIONS}

Platw 1. Map of Edgeley quadrangle showing areal geology ....... In pocket.

2. Map of La Moure quadrangle showing areal geology

3. Map of Edgeley quadrangle showing thickness of glacial drift and artesian-water conditions......... In pocket.

4. Map of La Moure quadrangle showing thickness of glacial drift and artesian-water conditions......................... In pocket.

5. Glacial moraines: $A$, Terminal moraine on Coteau du Missouri; $B$, Oakes moraine, a recessional moraine.....................

Figdre 1. Index map of parts of North and South Dakota showing location of Edgeley and La Moure quadrangles................

2. Sketch map of North Dakota and adjacent areas showing the principal physiographic divisions of the region...........

3. Sections of wells in the Edgeley and La Moure quadrangles..-

4. Map showing area covered by the North American ice sheets and the mountain glaciers of the Pleistocene epoch at the maxi-

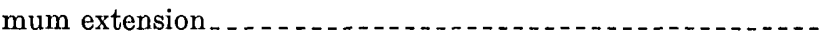

5. Sketch map showing southwestern limit reached by the Pleistocene ice sheets and the distribution of moraines of the Dakota glacial lobe of the Wisconsin stage of glaciation..........

6. Map of the northern part of the Ellendale quadrangle showing decline in artesian head . . . . . . . . . . . . . . .

7. Generalized east-west section of the area of artesian flow in the Edgeley quadrangle, 'showing hydraulic profiles.......- 



\title{
GEOLOGY AND WATER RES0URCES OF THE EDGELEY AND LA MOURE QUADRANGLES, NORTH DAKOTA
}

\author{
By Herbert A. Hard
}

\section{INTRODUCTION}

\section{LOCATION AND GENERAL RELATIONS}

The Edgeley and La Moure quadrangles lie between meridians $98^{\circ}$ and $99^{\circ}$ and parallels $46^{\circ}$ and $46^{\circ} 30^{\prime}$. The area comprises nearly all of Dickey County, the southern two-thirds of La Moure County, and

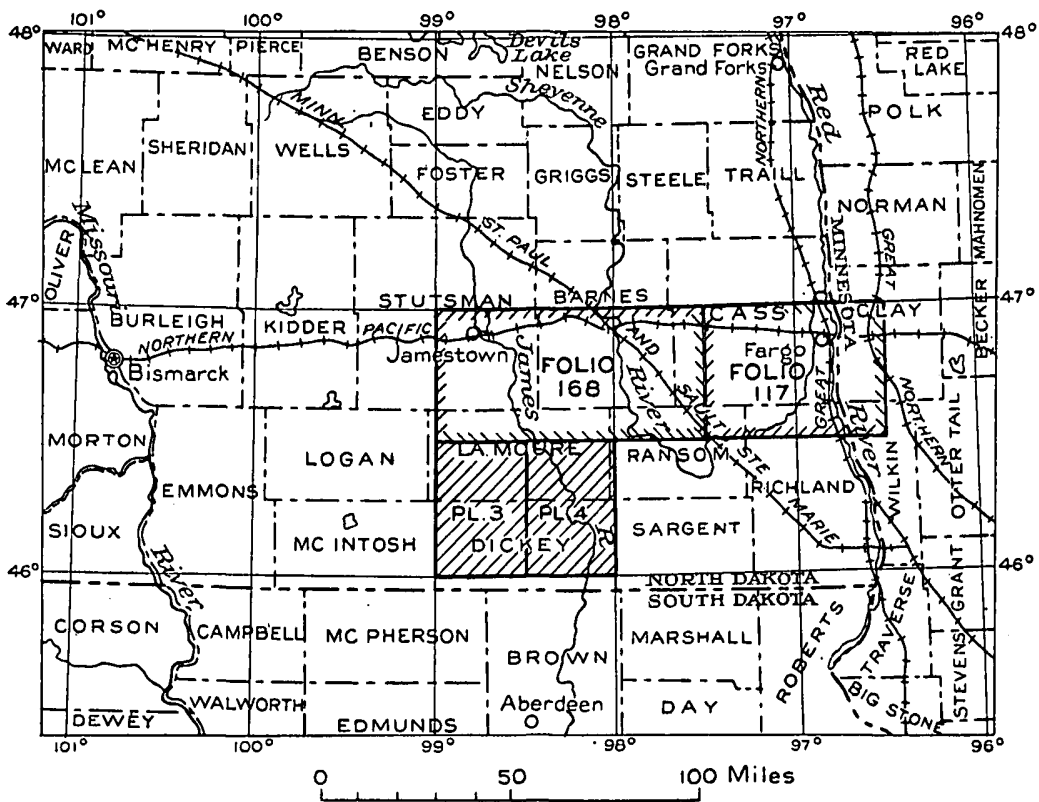

Frgdre 1.-Index map of parts of North and South Dakota showing location of Edgeley and La Moure quadrangles and areas covered by Jamestown-Tower and

Casselton-Fargo folios (Nos. 168 and 117) of the Geologic Atlas

small strips along the western edges of Ransom and Sargent Counties, N. Dak. (See fig. 1.) Each quadrangle is about $241 / 3$ miles wide and $341 / 2$ miles long and therefore covers about 840 square miles. Oakes and Ellendale, in Dickey County, and Edgeley and La Moure, 
in La Moure County, are thriving towns with good railroad facilities for handling agricultural products, which are about the sole resource of the region. Ellendale and La Moure are county seats.

The Edgeley and La Moure quadrangles lie in the western part of the Western Lake section of the Central Lowland. This lowland extends from the Appalachian Highlands on the east to the Great Plains on the west. The Edgeley quadrangle overlaps the Coteau du Missouri, which here marks the limit of the Great Plains. ${ }^{1}$

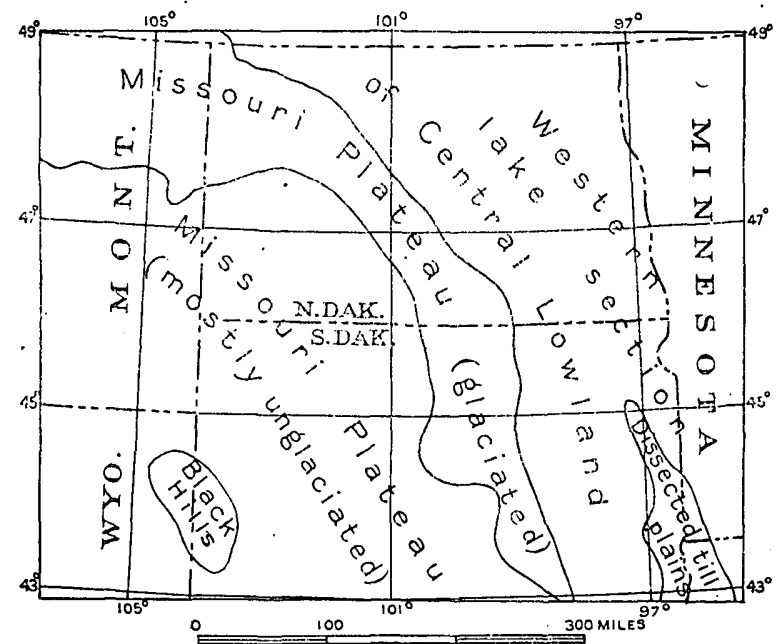

Frgore 2.- Sketch map of North Dakota and adjacent areas showing the principal physiographic divisions of the region

The Western Lake section extends from the margin of the plateau in the Edgeley quadrangle eastward to the Laurentian Upland in Minnesota and southward to the Dissected Till Plains in eastern Nebraska and Iowa. It embraces the area covered by the combined Minnesota and Dakota lobes of the last ice sheet.

The region is traversed by some of the more prominent glacial moraines of the United States, and the rugged Gary and Altamont moraines cross the western part of the Edgeley quadrangle.

\section{GENERAL FEATURES OF NORTH DAKOTA}

As a setting for the description of these quadrangles a brief summary of the general features of North Dakota is given below.

\section{TOPOGRAPHY}

North Dakota comprises three areas which are characterized by somewhat different surface features. (1) The eastern tier of counties, forming a belt 30 to 40 miles wide, lies on the smooth floor of glacial Lake Agassiz, which is now the valley of Red River. This level tract, some 700 miles in length, extends far into Canada, where it has a maximum width of about 250 miles. Its total area is about 110,000 square miles. (2) From the Herman beach and the low Manitoba

\footnotetext{
1 The classification here given is in accordance with the outline of the physiographic divisions of the United States adopted by the Association of American Geographers and approved by the United States Geological Survey.
} 
escarpment the rolling glaciated prairie plain rises gradually westward to the Coteau du Missouri, which is the eastern margin of the Great Plains. The eastward-facing Coteau escarpment is 30 to 90 miles east of Missouri River and runs diagonally across the State from northwest to southeast, roughly dividing it into halves. The glaciated area extends westward 25 to 80 miles beyond the Missouri River gorge and thus overlaps the Great Plains for 150 miles or more. (3) The remaining area, comprising several counties in the southwestern part of the State, is unglaciated. Here the surface is in the main a rolling, moderately dissected upland, above which rise a few isolated buttes. Near the main streams the smaller valleys are more sharply cut, and in places a multiplicity of ravines and erosion remnants produces a picturesque badland topography.

The altitude of the State ranges from 751 feet above sea level where Red River crosses the international boundary, near Pembina, to 3,468 feet above sea level on Black or H. T. Butte, in southwestern North Dakota. That part of the Western Lake section in which the Edgeley and La Moure quadrangles lie ranges from about 1,000 to about 2,000 feet in altitude. The Coteau du Missouri, which is more fully described below, the Coteau des Prairies, and the Turtle Mountains, standing 300 to 800 feet above the surrounding plain, are among the few more prominent features of the region. The Coteau des Prairies extends through southwestern Minnesota and northeastern South Dakota and reaches an altitude of 2,000 feet at its north end. This is a broad, gentle ridge rising about 500 to 700 feet above the adjacent country. In North Dakota it is represented by a mere swell in the prairie that continues northward across the State with low relief but gradually rises until, near the international boundary, it merges into the highland known as Pembina Mountain, which stands 360 feet above the plain where it enters Canada. North of the Coteau des Prairies this feature is known as the Manitoba escarpment. It continues far into Canada, where it becomes more conspicuous. Along parts of its course Missouri River has trenched its immediate valley 200 to 300 feet, Sheyenne River 200 feet in places, and James River 100 feet.

\section{DRAINAGE}

The drainage of North Dakota is about equally divided between two great systems-that of ${ }^{\circ}$ Red River, a tributary of Nelson River, leading to Hudson Bay, and the Missouri-Mississippi system, emptying into the Gulf of Mexico. Owing to light rainfall and the comparatively recent drift deposits the drainage of most of that part of the State east and north of Missouri River is not mature, and many local areas are undrained. 
BEDROCK SURFACE

Northeast of Missouri River the State is so heavily covered with glacial drift that only the general configuration of the bedrock surface can be determined. Drift and lacustrine deposits are in places several hundred feet thick, so that the only data obtainable are those afforded by the logs of deep wells. East of the Manitoba escarpment there is a great north-south valley in the bedrock corresponding in position to the present valley of Red River. This valley was eroded through the Cretaceous deposits into Silurian, Ordovician, and Laurentian rocks. Its bottom is lower toward the north, sloping from about 800 feet above the sea in the southeastern part of the State to about 500 feet at the Canada boundary. West of this valley, as far as the Coteau du Missouri, the general altitude of the rock surface ranges from 1,200 to 1,500 feet above the sea. This general plain ranges in width from 75 miles at the south boundary of North Dakota to 200 miles at the Canada line. It is cut more or less by ancient valleys, now buried under the drift. Records of many artesian wells drilled through the drift filling in the James River valley show a deeply buried valley corresponding approximately in position to the present valley in North Dakota. The surface of the rock rises somewhat higher to the west beneath the Coteau du Missouri, but a large part of the present relief of the Coteau, at least near its east front, is probably due to a thick accumulation of glacial drift.

\section{STRATIGRAPHY AND STRUCTURE}

The deposits that underlie the glacial drift in the Dakotas are chiefly almost horizontal beds of Cretaceous and Tertiary sediments. The mantle of glacial drift is so heavy that the Pierre shale, which underlies the eastern part of the two States, is rarely exposed. The same is true of the Fort Union beds westward to the Missouri, but farther west the veneer of older drift is so thin and discontinuous that the Fort Union strata are exposed in many ledges in mesa fronts and valley slopes. These rocks are so soft and shaly that east of the Missouri they were smoothed by the overriding ice and generally do not have any marked influence upon the present topography except in a large way.

In the artesian basin that forms the eastern third of North Dakota the Cretaceous strata have a general southwesterly dip nearly to the south State line, where they bend upward. The dip to the west is over $11 / 2$ feet to the mile, and the southerly dip is about 6 or 8 feet to the mile. These strata are flexed strongly upward on the slopes of the Black Hills and the mountains farther west. 
Granite has been reached in a few wells in North Dakota. Except possibly the Oakes well, these are in the eastern part of the State, where in a small area granite underlies the Dakota sandstone (or the shale where the Dakota is absent) at depths of 250 to 500 feet. In the northeast corner of the State Ordovician and Silurian strata are interposed between the drift and the granite, which is reached at depths of 800 to 900 feet. Thus the granite is found at very different depths in the different wells, indicating unequal erosion before Cretaceous deposition.

\section{SETTLEMENT OF THE QUADRANGLES}

The Edgeley and La Moure quadrangles lie in an agricultural region which is thinly populated. Most of the farmers own much larger tracts than they can properly till, and as a result of poor tillage and scant rainfall the yields are less than half what the land could produce. With the application of scientific management farming has been found to be a profitable occupation, as the region is uniformly fertile. The area is well served with railroads, being crossed by five lines, so that all parts of it are within a reasonable hauling distance from the elevators. The Bismarck branch of the Minneapolis, St. Paul \& Sault Ste. Marie Railway, the Fargo \& Southwestern branch of the Northeri Pacific Railway, and the Ellendale branch of the Great Northern Railway cross the area from east to west, and the Chicago, Milwaukee \& St. Paul Railway and Midland Continental Railroad form one north-south line, and the Jamestown line of the Northern Pacific Railway another.

In the Sioux war of 1863 General Sully visited this region to clear: it of Indians and avenge the massacres of New Ulm, Minn., and Spirit Lake, Iowa. He surprised the Sioux at Whitestone Hill, 7 miles southwest of Merricourt, in the NW. 1/4 sec. 17, T. $131 \mathrm{~N}$, R. $65 \mathrm{~W}$, where they were encamped while hunting ibuffalo and preparing their winter's supply of meat and furs. He attacked them at night, and the withering cross fire from the surrounding hills quickly put them to rout. Sully estimated the number of Indians in the camp at 3,000 to 4,000 , including 1,500 men. He reported to the Government 450 killed, but early settlers who found the skeletons still on the field estimated them at 1,500. Men, women, and children alike were shot or put to the bayonet. Later the bones were gathered up with those of the buffalo and shipped from Ellendale.! Largely through the efforts of the late Theodore Northrup, of Monango, local and State interest was aroused, and in October, 1909, a granite shaft commemorating the battle was erected on Whitestone Hill.

The first important bodies of settlers came in 1881-1885 from the Eastern States and from Norway and Sweden. Comparatively few 
of these persons still remain, as some have been discouraged by drought and hard times and others, more prosperous, have been caught in the drift to city life. These have been replaced by a slow but steady influx of others. The level country has a large proportion of Scandinavian population, and the rough hill country at the southwest is almost entirely inhabited by Russians.

The Chicago, Milwaukee \& St. Paul Railway was built into Ellendale from the south in 1881, and after that the surrounding country, largely unsurveyed and occupied by "squatters," was rapidly homesteaded. In 1886 the Chicago \& Northwestern Railway and Northern Pacific Railway were extended to Oakes. In 1887 the Soo Line was built through Oakes to Merricourt and the Great Northern to Ellendale. The Fargo \& Southwestern branch of the Northern Pacific had previously reached Edgeley.

The population of the area is about 20,000 . Oakes is the largest town, with a population (in 1920) of 1,637. Then follow Ellendale with 1,400, La Moure with 1,014, Edgeley with 803, Kulm with 725, Forbes with 293, Verona with 258, Monango with 231, and Fullerton with 202. In 1915 there were 22 banks and 9 newspapers in the area. Telephone service is general throughout the country, and there are many rural mail routes.

The staple products of the region are wheat, oats, and barley, with a decreasing amount of flax and a rapidly increasing amount of corn, alfalfa, and livestock. Brome grass, millet, and prairie grass constitute most of the hay.

\section{TOPOGRAPHY}

\section{RELIEF}

This region is so deeply buried under the deposits of repeated glaciation by the Dakota ice lobe that the bedrock affects the surface only in a general way, but the La Moure and Edgeley quadrangles are of geologic interest in that they contain a series of glacial features. Skirting the eastern margin is a range of hills which is here designated the Oakes moraine. In the southeastern part of the area there is a portion of the silted floor of the extinct glacial Lake Dakota.

For 35 miles west of these features the topography is that of a nearly flat plain, interrupted only by the 100 -foot gorge of James River in the east and the shallow valley of Maple River farther west and traversed by two faint disconnected moraines. This generally level plain ends in R. $65 \mathrm{~W}$, at the foot of the abrupt east front of the Coteau du Missouri, which rises westward 200 to 400 feet within a distance of a few miles. This escarpment, composed in this region of glacial drift, is capped by the Gary and Altamont moraines. 
Along the south half of the portion of the Coteau included in this area these two moraines are practically continuous through a belt 6 to 10 miles wide. At the Gary substage the ice that formed the moraine barely overtopped the escarpment, and thus its deposits lie on the edge of the upland, where they form rough bouldery hills with a relief of 25 to 100 feet and give a topography rivaling that of the badlands in irregularity.

The altitude of the area mapped ranges from 1,300 feet above sea level in the southeastern part along and east of James River to 2,200 feet on the hilltops of the Gary moraine in the southwestern part.

\section{LAKE AND RIVER PLAINS}

The level floor of glacial Lake Dakota comprises about 65 square miles, or one twenty-fifth of the area. It is about 8 miles wide at the south boundary, maintains this width for 8 miles north, and then rapidly narrows to a point 4 miles north of Oakes. The plain varies less than 10 feet in altitude, except where it is trenched by James River. Near the north end of this plain the James River Valley opens a mile wide into the upland and continues northward at about the same altitude, 1 to $2 \frac{1}{2}$ miles wide, throughout the area. Parts of the old lake and river bottoms covering many square miles are as level as a floor. Low dunes, or hills of wind-blown sand, constitute about the only break in the level surface. Only in secs. 19 and $30, T$. 130 N., R. 58 W. (Jackson Township), do the dunes reach notable height; there they form an isolated group about 50 feet high. A low islandlike ridge that has escaped erosion rises above the general level of the plain in the western part of Riverdale Township. The level lake plain extends a few miles eastward beyond the La Moure quadrangle and about 90 miles southward in South Dakota.

No distinct terraces bound the lake floor, but many isolated terrace remnants, or barlike forms, are found to the north in the James River Valley, alternately on each side of the river.

\section{UPLANDS}

North and east of the lake plain rise the sharp hills of the Oakes moraine, which occupies a narrow strip 1 to 4 miles wide to the north boundary of this area but lies chiefly in the quadrangle to the east. It is roughest just north of the plain described above, where a few hills reach an altitude of 1,400 feet, 100 feet above the general level to the south. From this point northward the relief is 10 to 50 feet. For 35 miles to the west the gently undulating prairie is interrupted only by low swells and subdued knolls with a relief of less than 20 feet and by the valleys of James and Maple Rivers. A subdued 
morainal tract that extends from north to south through the central part of the $\mathrm{La}$ Moure quadrangle includes many undrained areas ranging from a few acres to several square miles in extent. Only one of these holds a permanent lake, but many are marshes in wet seasons. Many formerly held lakes and show flat filled bottoms and ice-rampart banks.

From R. 61 westward the surface gradually rises at the rate of about 100 feet in 6 miles to the base of the Coteau and is of nearly uniform slope except for the narrow trench of Maple River and a subdued and discontinuous moraine that extends southward from Edgeley. Two illusions are very commonly experienced in traversing this plain. Over most of the smoothest part the traveler is constantly deceived by the feeling that he is in the bottom of a great basin which gently rises on all sides of him for several miles. As he continues at the same altitude the illusion persists; he still seems to be at the bottom of a broad, shallow depression. Also on approaching the Coteau from the east for 6 to 8 miles, although the observer is looking up an incline that averages nearly 20 feet to the mile, he has a strong impression of looking downhill, so striking is the contrast between the slope of this plain and the abrupt front of the Coteau. It is not strange that the inhabitants of Dickey County refer to this area as the "Merricourt Valley," although it is a monoclinal slope. As the traveler mounts to the 1,700-foot level on a slope of 80 feet to the mile the hallucination still persists that he is going downhill. To perplex him further, as he turns to the east and looks downhill, he seems to see a strong upgrade, and only when he reaches the steep pitch above the 1,700-foot level does the illusion disappear.

In Dickey County the moraine-capped escarpment rises 100 to 300 feet to the mile. The maximum grade is 200 feet in a quarter of a mile in the NE. $1 / 4$ sec. 7, T. 129 N., R. 65 W. Much of this steep slope in Dickey County and the first 2 to 3 miles of the roughest portion of the upland above are very bouldery. Farther west great fertile amphitheaters and beautiful valleys lie among the morainic hills. From the center of T. $132 \mathrm{~N}$. northward through La Moure County the Coteau front has a much gentler slope. West of this front the surface is rough or sharply rolling and generally morainic. A large number of undrained depressions mark the sites of wet-season marshes and lakelets; practically all were dry when mapped in November, 1914, though some were evidently lakes when the topography was mapped in 1892-93.

\section{DRAINAGE}

There are two principal drainage systems in the area-those of James River and Maple River. In the tract west of the Coteau front in Dickey County and much of La Moure County no drainage sys- 
tem has been established, the scant rainfall being caught and for the most part held by the great intermorainic troughs till it evaporates or soaks into the ground. Many tracts in the broad central prairie area also have no drainage. Many of these tracts have become alkaline by the continued evaporation of water leaving its salt behind. A notable example is the tract of "gumbo" soil 2 to 3 miles wide extending from north to south across Dickey County west of Monango. Here the drainage is obstructed by blocking by the faint outer moraine of the Antelope morainic system.

\section{JAMES RIVER}

James River is the only body of water of any size and the only permanent stream in the area. Even in this stream the reeds grow, and grass floating in its channel attests the sluggish current, which scarcely moves in the driest seasons. The river is 2 to 6 feet deep and 20 to 30 feet wide. Its banks are abrupt and usually 5 to 10 feet high. It never overflows the valley bottom in this area. It flows south by southeast, entering the northwest corner of the La Moure quadrangle and leaving near the southeast corner; it falls about 20 feet in about 45 miles. The stream is close to the 1,300-foot level from a point about 1 mile north of Grand Rapids to the south boundary of the area.

At the north edge of the area the valley is 1 mile wide; 1 mile farther south it bends sharply to the southeast and gradually widens to $2 \frac{1}{2}$ miles. It sweeps in a series of broad curves and maintains a width of $1 \frac{1}{2}$ to $21 / 2$ miles through La Moure County and into Dickey County to T. 132 N., R. 60 W., where the river intersects the low morainic tract. Here the valley is narrowed at several points. Farther on it is joined by Bear Creek Valley and opens out to the broad plain of glacial Lake Dakota. A shallow trench, half a mile to $11 / 2$ miles wide and 10 to 20 feet deep, has been cut by the river along the west border of the plain.

The large size and majestic sweep of the James Valley present an impressive contrast with its diminutive river. This valley is uniformly about 100 feet deep for about 30 miles, from the north boundary of the area nearly to the mouth of the Bear Creek. The bluffs are for the most part so steep that roadways are made only with much grading in selected places. Generally there is a 75 -foot rise within a few rods, but in places large terraces or benches interrupt the slope. The bluffs are everywhere composed of glacial drift, the underlying rock being nowhere exposed. In secs. 5 and 6, T. 131 N., R. 59 W., where the James River Valley broadens into the Lake Dakota basin, the east bluff gives place to a gentle slope 10 to 15 feet high. The stream closely follows the west bluff, which gradually 
lowers from a height of about 70 feet in sec. 5, T. 131 N., R. 59 W., to a gentle slope in sec. 25, T. 130 N., R. 60 W. South of this locality a portion of the Lake Dakota plain lies on the west side of the river, and this rises gently and merges into the plain on the west.

\section{BEAR CREEK}

Bear Creek enters the northeastern part of the La Moure quadrangle, flows in a general southerly direction for about 25 miles, and empties into the James in sec. 17, T. 131 N., R. 59 W. Its valley, like that of the James, is cut all the way in drift. For the first 5 or 6 miles of its course in this area it flows through an almost level plain, the southern extension of Sand Prairie. Here it forms but a shallow trench in the prairie, inconspicuous except to a person near by. In sec. 25, Verona Township, the creek passes close to the base of the Oakes moraine. Here it channels slightly higher land and has a deeper and narrower valley, which persists throughout the remainder of its course. This stretch, which is 20 to 50 feet below the plain on the west, skirts the moraine on the east. In the SW. 1/4. sec. 4, Bear Creek Township, its valley opens out into the constricted north end of the Lake Dakota plain. Bear Creek receives no large tributaries, but springs make it a permanent stream in its lower course, in which it falls about 85 feet in about 30 miles.

\section{MAPLE RIVER}

Maple River is an intermittent stream occupying a large valley that is out of all proportion to the present small drainage. It originates in numerous intermittent streams that head in the Coteau and the Gary moraine. Many of these streams unite in T. 133 N., R. 63 W., and T. 132 N., R. 64 W., to form the north and south forks, respectively. The forks unite in the NE. $1 / 4$ sec. 10, T. 131 N., R. 63 W., whence the river flows east past Fullerton to sec. 24, T. $131 \mathrm{~N}$., R. $62 \mathrm{~W}$., thence south, leaving the area in sec. 11, T. 129 N., R. $62 \mathrm{~W}$. The stream, including its longest tributary, flows for more than 60 miles in the area and falls 590 feet, from the 1,960-foot to the 1,370 -foot contour. The channel is for the most part cut in glacial drift, although several of the intermittent creeks have cut into shale in Tps. 132 and 133 N., R. 64 W. The major stream has exposed the shale at the base of its bluff in sec. 4, T. 131 N., R. 63 W., and sec. 33 , T. 132 N., R. $63 \mathrm{~W}$. This is the easternmost exposure of the bedrock in the area. The south fork of the Maple crosses the low outer Antelope moraine south and west of Monango. All of that part of the Maple River Valley lying in R. $63 \mathrm{~W}$. and extending for 2 miles into 
R. $62 \mathrm{~W}$. has steep bluffs 40 to 50 feet high, cut in drift, except at the place noted above. South of Fullerton the valley is shallow, with banks usually 10 to 20 feet high. Thus above Fullerton the topography along the river is rough, but to the south it is smooth. Near Fullerton two broad, shallow glacial drainage channels join the Maple Valley from the north. The one that joins in sec. 16, Maple Township, still discharges an intermittent stream. The channel that joins in sec. 23, Maple Township, is but a few feet above the river level, so that occasionally in the spring, when ice gorges form in sec. 24, the rising water is ponded up the minor channel for 3 or 4 miles, and small lakes are left in the depressions of its bed when the flood subsides. From the La Moure County line southward the Maple has a narrow alluvial flood plain, gradually increasing in width from a few rods to 1 mile. Here and there are benches of sand and gravel, made when the stream had a greater volume and a capacity to erode the large valley it now occupies.

\section{ELM RIVER}

South of sec. 15, T. 131 N., R. 65 W., the small streams collected from the Coteau front unite to form Elm River, which in this area is an intermittent stream in a shallow valley. It leaves the 'south boundary in sec. 10, T. 129 N., R. 64 W.

\section{LAKES}

The only natural lakes in this area that are worthy of mention are the diminutive alkaline Twin Lakes, in the western part of $\mathrm{T}$. 134 N., R. 60 W., in the La Moure quadrangle. These lakes lie in a large depression in morainal deposits. They have no outlet and exist only because their basin is large enough to catch just a little more water than can evaporate during the long dry seasons. Shimmin, Wirch, and Crow Lakes, in the southwest corner of the area, are tiny permanent spring-fed water bodies. In the spring and after a succession of wet years a great number of depressions all over the area, especially in the morainal tracts, are converted into small lakes. These endure a number of months or some of them even years, according to the depth and porosity of their basins. Most of them, however, are dry long before winter. A few, such as those in western Ovid and Clement and eastern Wright, Yorktown, and Kent Townships, persist in shrunken size for a short period of moist years. These were all dry when both the topographic and the geologic surveys were made. Raney Lake, in the northwestern part of the area, was also dry when visited by the writer.

$6147-29-2$ 


\section{SPRINGS}

East of the Coteau the springs are almost entirely restricted to the stream valleys, usually being found at the base of the bluffs, where the stream has exposed a porous sand or gravel stratum. Few of them give large flow, but they materially supplement the local water supply. Probably most of the permanent water holes along Maple River and Bear Creek are due to springs, as well as much of the water in James River in dry seasons. On the Coteau, where rainfall is less and permanent bodies of surface water are rare and where the artesian flow will probably never reach the surface, there are fortunately many small springs. These issue from the ground in the depressions and form pools in the beds of the usually dry stream courses. They are of great value on the farms and grazing lands.

\section{CLIMATE AND VEGETATION}

The Edgeley and La Moure quadrangles have the prevailing northern midcontinental climate, with short, mild summers and long, cold winters. The growing season averages about 105 days, though it ranges from 76 to 150 days. Light frosts may occur in midsummer, but these are seldom 'injurious. The average date of the last killing frost in the spring is about June 1 , and that of the first in autumn September 15, though frost may occur as late as June 20 :and as early as August 20. As the air is dry, it is only when severe winds are blowing that the low temperatures are very disagreeable. At such times the typical blizzard develops. The prevailing winds blow from the northwest. A frost penetration of 4 to 6 feet is common, as the snowfall is usually light and soon drifted.

The temperature exhibits a wide range during the year. In July and August it occasionally reaches $100^{\circ} \mathrm{F}$., but even after the hottest days the nights are always cool. Five to ten days is the limit of the hot weather each summer. In winter the temperature often drops to $-25^{\circ}$ and occasionally to $-40^{\circ}$ and remains close to these marks for some days. The mean annual temperature for the State for the -25-year period 1892 to 1916 was $38.7^{\circ}$; for this area in the 16 years 1901 to 1916 it was $40.0^{\circ}$.

The annual precipitation in the area mapped ranges from 10 to 25 inches; the average is the same as that for the State, 18.10 inches. The snowfall ranges from a few inches to $51 / 2$ feet annually but is only a small fraction of what is popularly attributed to the Dakotas. Normally 75 per cent of the precipitation falls in the spring and is therefore available for plant growth. W J McGee, in conversation with the writer, estimated that the underflow of water from the Black Hills, Big Horn Mountains, and Rocky Mountains and its upward seepage from the artesian strata made available for crop use 
in the Dakotas an amount of water equivalent to 3 or 4 inches of rainfall and that the production in these States is proportionate to an annual water supply exceeding the rainfall by that amount.

Formerly this region was considered fit only for grazing. Now, with improved methods of farming, practically all of it can be put under the plow, and only small areas of the rougher or more sandy land need be left for pasture. This typical prairie was practically treeless, a few of the ravines in the Coteau front having brush and stunted trees and the James River Valley a few little groves. The trees planted on the early tree claims were usually little fitted to the climate, and, without cultivation to conserve moisture, nearly all of them died. Although a few groves of well-selected varieties were planted later and cultivated, little has been done to break the monotony of the bleak prairie. As evidence of what can be done a nurseryman at Fullerton has 200 varieties of woody plants that are able, with proper attention, to withstand the rigors of cold and drought. A few hardy varieties of apple, plum, and cherry and of the berries can easily be grown.

\section{DESCRIPTIVE GEOLOGY}

The area of the La Moure and Edgeley quadrangles, like that of most of North Dakota, is mainly covered with a thick mantle of glacial drift and in part with glacial-lake silt and alluvium. These deposits are described at length under the heading "Pleistocene." The only consolidated or semiconsolidated rock formation near the surface in this area is the Pierre shale, which underlies the drift at depths ranging from a few feet to several hundred feet. Some information concerning the deeper-lying deposits has been obtained from $\log \mathrm{s}$ of the many deep wells within the area. Granite has possibly been reached in one well at Oakes at a depth of over 1,300 feet but is believed to underlie the whole area. Upon this crystalline bedrock, whose surface rises toward the east, lie the almost horizontal stratified rocks. In the wells at La Moure and at Jamestown, 30 miles north of this area, limestone of probable Paleozoic age is reported.

\section{CRETACEOUS SYSTEMI}

The Dakota sandstone and the Benton, Niobrara, and Pierre shales are shown by the records of the well borings to underlie this area. The total thickness of the shales underlying the drift and overlying the Dakota sandstone ranges from 700 feet at the east side of the area to perhaps 1,600 feet at the west side. The nearly horizontal Benton and Pierre shales are separated by a poorly defined zone of the calcareous Niobrara shale. 


\section{DAKOTA SANDSTONE}

Depth and thickness.-The Dakota sandstone (fig. 3), the lowest of the Upper Cretaceous deposits, does not crop out in North Dakota. It is, however, reached by deep wells throughout an extensive area in both the Dakotas, and it is of great economic importance as the source of abundant artesian water in a subhumid region. It lies at depths ranging from about 200 or 250 feet near the east line

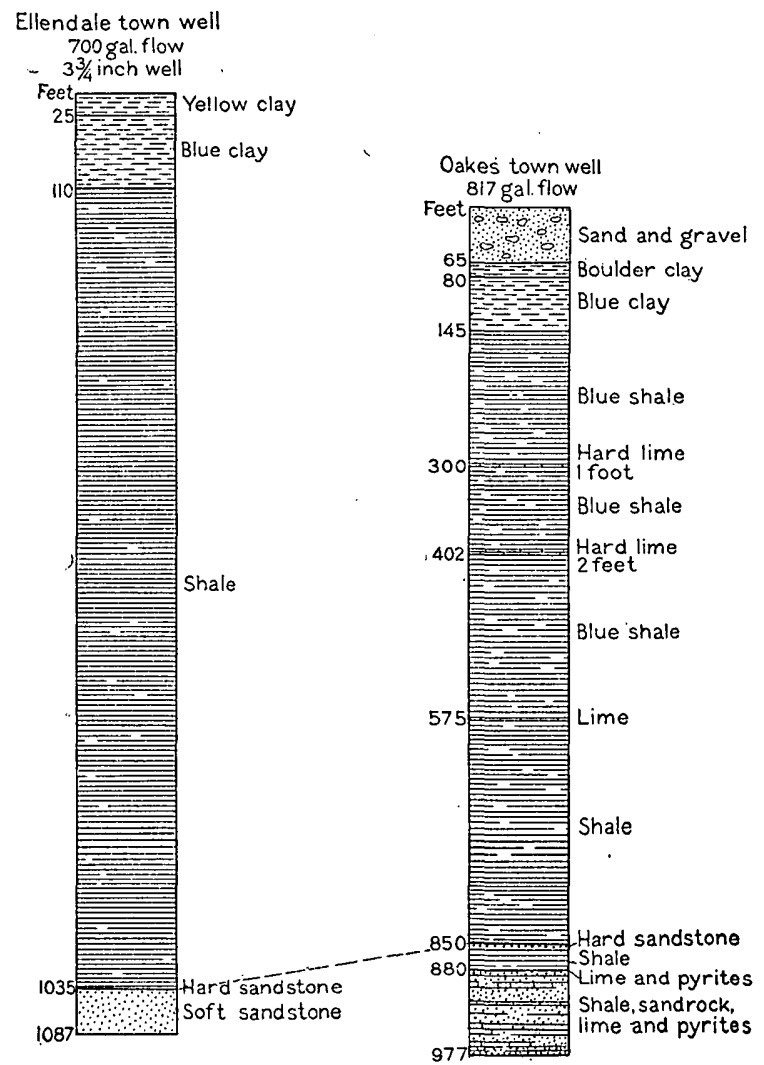

Figure 3.--Sections of wells in the Edgeley and La Moure quadrangles

of North Dakota to 1,450 feet at Jamestown. Several wells near Oakes, in the La Moure quadrangle, reach it at depths of 790 to 900 feet, but a 2,000foot well on the high land in the western part of the area failed to reach the bottom of the shale. The relations of this important water-bearing stratum are shown in Figure 3.

Numerous wells penetrate the sandstone to depths ranging from 1 to 450 feet or more. The deeper wells indicate a thickness of 400 to 500 feet. The differences in the depth at which water is struck might be taken to indicate that in places the sandstone was eroded before the overlying Benton was laid down, though the very general conformity between the Dakota and Benton renders this inference rather improbable. The differences are more probably due to the discontinuity of the water-bearing lenses as originally laid down, and to irregularities in the surface upon which the Dakota was deposited.

Character.-The Dakota sandstone in South Dakota has repeatedly been described ${ }^{2}$ as a brown or gray rock with a thickness of 300 to

2 Darton, N. H., Preliminary report on artesian waters of a portion of the Dakotas: U. S. Geol. Survey Seventeenth Ann. Rept., pt. 2, p. 612, 1896. 
400 feet, comprising a relatively thin but widely extended sheet of sand and intercalated beds of clay and streaks of pyrites. As described from its outcrop in the Black Hills ${ }^{3}$ and along Missouri River it is "a brown sandstone, hard and massive below, but thinner bedded and interstratified with much shale above." The Dakota consists of a great number of layers that range from a few inches to 100 feet or more in thickness and differ widely in shape and permeability. Some are uniform in thickness; others thin out or disappear altogether; some are lens-shaped. They range from coarse-grained, porous sand to fine, compact sand; some beds are so thoroughly consolidated and hard as to require many days of drill work to penetrate a thickness of a few feet; others are so loose as to cave in or to rise as slush from the drill. Some earlier drillers worked for several weeks on a few feet of "cap rock" encountered just above the first flow.

Fossils.-The Dakota sandstone has frequently been considered of fresh-water origin, owing to the fact that most of its fossil remains everywhere are land plants with a few fresh-water mollusks. In eastern Kansas and Nebraska, however, it has been found to contain invertebrate remains indicating that some beds are marine and others of brackish-water origin. In the Edgeley and La Moure quadrangles very few fossil remains aside from leaves of deciduous trees have been found. A shark tooth, indicating marine waters, was obtained from the Greenwald well, at Ludden. Imperfect specimens tentatively identified as Natica (marine), Corbula (brackish water), and Goniobasis (fresh water) were obtained from other wells. The fossil remains and the general character of the formation indicate that the Dakota sandstone was laid down along the coast of an advancing sea.

\section{COLORADO GROUP}

Numerous wells penetrate thicknesses of shały rock ranging from 700 feet beneath the James River Valley on the east to about 1,500 feet beneath the Coteau on the west. The difference in thickness is due in part to the gentle westward dip of the formations and to the fact that the preglacial James River Valley was eroded lower than the Coteau region. The composition of the shale does not differ much from top to bottom. However, some drillers have observed variations in composition in a zone that probably marks the position of the Niobrara shale.

\section{BENTON SHALE}

Above the Dakota sandstone lies the somber-hued Benton shale, named from its occurrence near Fort Benton, Mont. This is one of

s Darton, N. H., U. S. Geol. Survey Twenty-first Ann. Rept., pt. 4, p. 531, 1900 ; Geology and water resources of the northern portion of the Black Hills and adjoining regions in South Dakota and Wyoming: U. S. Geol. Survey Prof. Paper 65, p. 49, 1909. 
the most extensive and characteristic rocks of the Central Plains and is reported to range in thickness from 400 feet in the southeastern part of the plains to 1,600 feet in the Black Hills, ${ }^{4}$ and in southeastern South Dakota it ranges from 180 to 500 feet. $^{5}$ The Benton is reported to thicken from central South Dakota toward the north, and this statement is borne out by the records of wells in North Dakota. A few wells, indicated on the accompanying artesian-water maps (pls. 3, 4), obtained a flow of water from sands in the Benton, but most of its strata are compact, fine-grained shale. Pyrites is usually found on the contact with the Dakota.

Very few fossils were observed, Prionotropis woolgari, of the upper Benton, and Inoceramus labiatus being about the only ones reported. A shark tooth (Otodus or Odontaspis?) came from the Greenwald well, near Ludden. Pieces of lignite were taken out of this and many other wells.

\section{NIOBRARA SHATE}

The Niobrara shale was named from its exposure near the mouth of Niobrara River, in Nebraska, where it is a chalk rock 200 feet thick and is white, gray, or drab when pure and freshly excavated but weathers to a bright straw color or a buff. It becomes impure toward the north and merges into shale in South Dakota. Drillers in northern South Dakota and in North Dakota often find some variation in the character of the Cretaceous shale at about 300 feet above the Dakota sandstone. In some wells no difference was observed; in others the dark-gray Benton gives place to a shaly rock of somewhat lighter color and higher lime content. However, the variation is often so slight that it is observed only by the more careful drillers, and at its upper and lower limits the limy rock shades so imperceptibly and at different depths into pure shale that it can not be separated from the Benton below and the Pierre above. In many wells in the area mapped a notable stratum designated by the drillers the " 40 foot cap rock" is encountered. It too is about 300 feet above the Dakota and is described as a compact shale much harder than the strata above and below.

The thickness of the Niobrara in South Dakota ranges from 100 to 300 feet; in Colorado 800 feet of this formation has been observed. Aside from the 40-foot cap rock noted above, its thickness in the Edgeley-La Moure area is not determinable. Here it is massive, fine grained, and of uniform texture. This widespread formation

\footnotetext{
- Darton, N. H., Preliminary report on the geology and underground water resources of the central Great Plains: U. S. Geol. Survey Prof. Paper 32, p. 166, 1905.

Idem, p. 130.
} 
lies conformably on the Benton. The Benton and Niobrara crop out in the Pembina Mountains of northeastern North Dakota but with the Pierre shale are absent in the Red River Valley.

\section{MONTANA GROUP}

\section{PIERRE SHALE}

Thickness.-The Pierre shale, or lower formation of the Montana group, is the only preglacial rock formation that crops out in the area. (See pl. 1.) Here it is weathered and is so soft and claylike as hardly to warrant the term shale. It is one of the most extensive and thickest formations of the Great Plains, aggregating some 7,700 feet of rock north of Denver. In the Edgeley-La Moure area it ranges in thickness from 200 feet at the east, where it has suffered the maximum post-Cretaceous erosion, to perhaps 1,300 feet at the west. It consists of dark-gray soft shale of nearly uniform texture except for concretions of calcareous matter and pyrites.

Outcrop.-In R. 64 W., from Edgeley south, the drift mantle is very thin, and the underlying shale is exposed by erosion in the bottoms of many of the small coulees, as shown on the geologic map (pl. 1), at altitudes of 1,500 to 1,560 feet above sea level. About 10 miles farther east the drift is reported to be about 300 feet thick, and the surface of the Pierre is at an altitude of about 1,200 feet.

Thus the drift thins out as the surface of the shale rises. Nearly all the tributaries of Maple and Elm Rivers in R. 64 W. cut through to shale in many places. In many sections the shale lies but 2 to 5 feet below the surface, and fragments are often turned up by the plow. Road ditches are cut into it, and a soil auger usually brings it up. At the base of the 40-foot bluff on Maple River in sec. 33, Valley Township, and sec. 4, Keystone Township, a thickness of several feet of the shale is exposed for about a mile. For much of this distance the shale has been carved into a narrow terrace-like form. This outcrop is about 5 miles east of the series of exposures: in R. 64 W. and is the easternmost outcrop in the area and in southeastern North Dakota. It is practically impossible to measure the gentle westward dip of this clay shale.

Fossils.-No fossil remains have been found where the shale is exposed, and the well-drilling methods here in vogue are such as seldom yield any recognizable trace of organic remains. Only scant. and poorly preserved fragments of Lucina occidentalis (Morton), Baculites ovatus (Say), and Inoceramus sagensis (Owen) have been noted. 


\section{QUATERNARY SYSTEM}

\section{PLEISTOCENE SERIES}

\section{GENERAL GLACIAL FEATURES}

'The Edgeley-La Moure area is covered throughout its extent by a deposit of glacial drift. In parts of the area some of this material has been assorted by lake and stream action. (See pls. 1 and 2.)

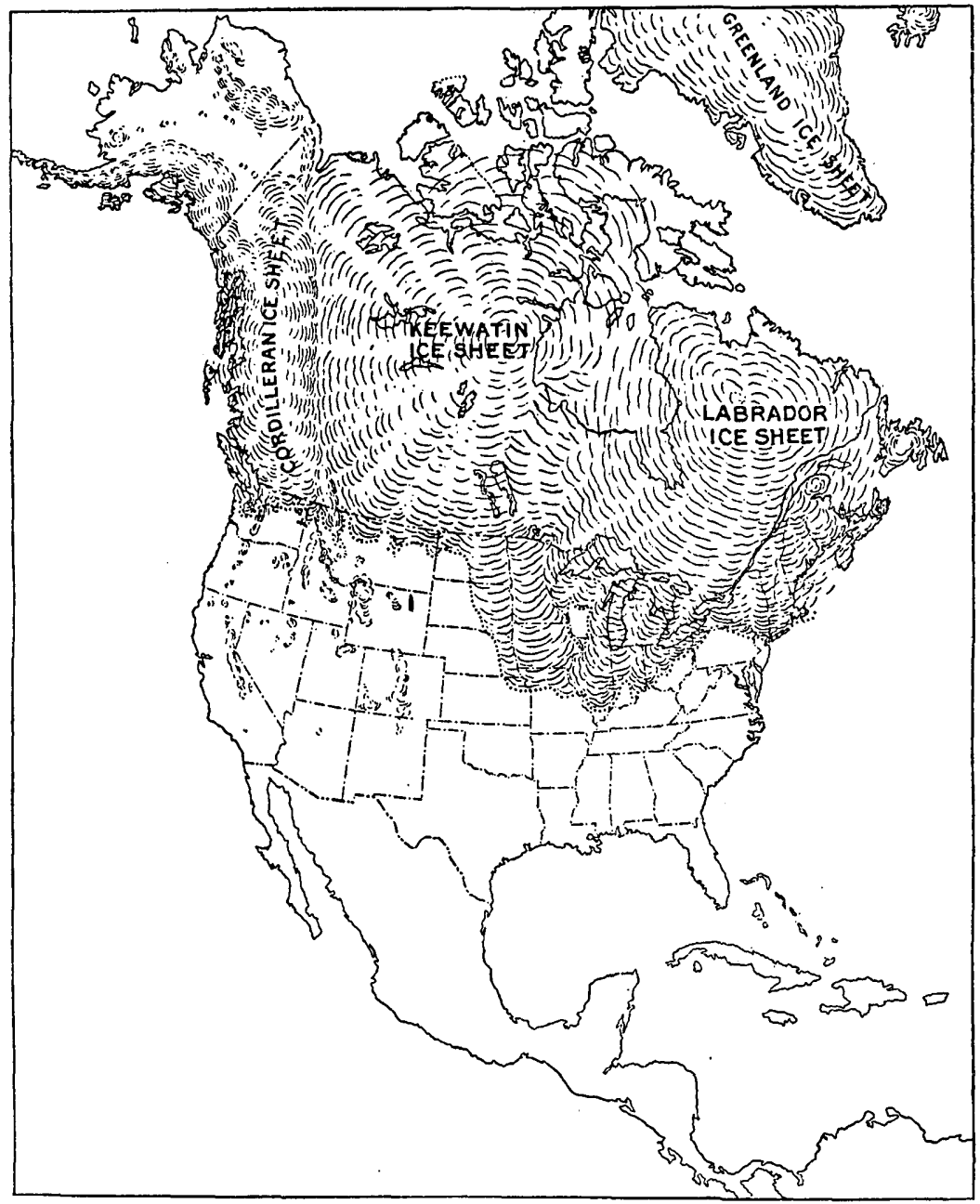

Figdrn 4.-Map showing area covered by the North American ice sheets and the mountain glaciers of the Pleistocene epoch at the maximum extension

This drift was the product of the advance and melting of the Dakota lobe of the great Keewatin ice sheet, which had its center of accumulation far to the north, in the area west of Hudson Bay. (See fig. 4.) It corresponds very closely in character with that in other parts of 
the State and adjacent States, which has been fully described in many other Federal and State reports.

No evidence has been found in this area on which to base subdivision of the drift into two or more sheets corresponding to different stages of ice invasion, as is possible in certain other areas.

Occasionally pieces of wood and other plant remains and traces of soil are reported as buried at various depths, but these are so rare and so isolated as to forbid any correlation to establish a definite horizon of interglacial deposits except in one or two localities. $\mathrm{Mr}$. Young, of La Moure, had many wells dug about Berlin and in the township on the north in which he found 6 inches to 2 feet of soil and wood buried at depths of 40 to 60 feet. J. F. Brenckle, M. D., and M. A. Noland report remains of trees, cones, leaves, grass, and fish as being found at depths of 18 to 30 feet north and east of Kulm.

The drift sheet ranges in thickness from 1 foot to 450 or 500 feet, as indicated on Plates 3 and 4. It was deposited in part beneath the moving glacier as till or boulder clay composing the ground moraine; in part about the margins of the melting ice lobes as terminal moraines. The material that was included within the glacier or carried on its surface was let down upon the ground moraine when the ice finally melted. Some of the drift was assorted and deposited by waters flowing from the melting ice.

No very deep railroad cuts have yet been made revealing the character of the drift within the Edgeley-La Moure area, though there are some from 10 to 15 feet deep. The Soo Line from Merricourt, at an altitude of 1,640 feet on the low prairie, to Kulm, upon the Coteau, 340 feet higher, makes the grade in 8 miles by easy stages and small cuts and fills along the Coteau front.

The drift generally consists of a mixture in various proportions of clay, sand, gravel, and boulders-that is, of till-with local interbedded underlying or surficial layers, seams, or pockets of stratified material, usually of gravel, sand, or silt. The clay matrix, which constitutes by far the larger part of the deposit, was derived principally from the Cretaceous shales of the immediate region. The boulders are generally granite, basalt, gneiss, schist, and dolomite brought from places far to the north, in Canada. The shales were soft and readily ground up by the moving ice or have since decayed to the consistency of clay. The superficial parts may have been already decayed, so that only exceptionally are masses found remaining intact in the drift. Notable instances of big masses of shale dislodged from the parent ledge and embedded unbroken in the drift are seen in the two prominent morainic hills in secs. 25 and 26 , T. 135 N., R. 66 W. Here boulders many feet in diameter are embedded in the hillside. These masses are tipped at various angles, as 
shown by their bedding planes, which are still preserved, though the shale is soft and friable. A huge cleft in one was excavated to a depth of more than 25 feet by early settlers in quest of gold, which was reported to have been found as small drift inclusions along the draw leading to the northwest. The bottom of the shale mass was not reached in any'of the several shafts. That these masses really were transported by the ice is shown by the fact that they are underlain by drift about 400 feet thick, as determined by well borings.

Deposits of sand and gravel are distributed promiscuously through the clayey till. They are the porous water-bearing portions of the drift. In certain localities a continuous layer may be traced from well to well over a considerable area. In some places the sand and gravel may represent interglacial deposits and mark the line of separation between drift sheets of different age. Where it is possible to determine the base of the till there is in many places a sand or gravel layer of varying thickness and texture. This may be the material washed out in front of the advancing ice prior to the deposition of the till. The porous strata are usually the principal source of water in the shallower wells. Under large areas this basal deposit of sand and gravel is absent, and as the dense clayey till is very much like the underlying Pierre shale in texture and color it is impossible at many places to determine the line of separation.

\section{COLOR AND OXIDATION}

The color of the till is bluish black below the water table and yellow or pale bluish yellow above, the color of the upper part being determined by the degree of oxidation of the iron salts in the till. The yellower zone of oxidation ranges in depth from a few inches to several feet. In this zone the iron has been oxidized to the yellow insoluble form, though it lacks the deeper yellow and red or reddishbrown shades characteristic of the more completely oxidized preWisconsin drift in the States farther east and south. In the zone of blue clay below the water table the oxygen is excluded, and the iron is unoxidized. The water carries soluble salts of iron.

\section{AGE OF THE DRIFT}

Leaching.-The surface of the drift of the Edgeley-La Moure area has been only slightly modified by erosion, and the drift has lost very little of its lime content by leaching. In this respect it shows characteristics of drift of the last or Wisconsin stage of glaciation, in contrast with that of the older sheets in areas farther east, which has been much eroded and from the upper part of which much of the calcareous matter has been removed by percolating water. Even the surface soil in this area is rich in lime. In many places the 
drift masses are weakly cemented together, and in most localities the under sides of rocks lying on the surface are covered with lime incrustation.

Induration.-The true ground morainic deposits, usually at a depth of several feet below the surface, are well compacted but nowhere show as high a degree of induration as some of the pre-Wisconsin drift of other localities. Very hard clay is reported to have been encountered in drilling wells in some places. This may be the earlier drift, now mantled by the Wisconsin. It is not exposed in any valleys or cuts within the Edgeley-La Moure area. Although no buried boulder pavements were found in these quadrangles, the writer found a fine example in the cut for the new Northern Pacific Railway line at Valley City, in the Eckelson and Tower quadrangles, just to the north. The excavation was made since those quadrangles were mapped. There a straight line of boulders, evidently the edge of a boulder pavement, buried 6 to 12 feet below the surface of the ground, was exposed for about a mile in the steep side of the cut.

\section{GLACIAL BOULDERS}

About two-thirds of the boulders on the surface in the EdgeleyLa Moure area consist or gray or pink granite. The remainder are dolomitic limestone, gneiss, and dark basaltic rocks in about equal proportions. The dolomitic limestone blocks, which are very abundant in small areas, amounting perhaps to one-third of all the boulders, are usually gray, though some are pink. Many boulders are striated or polished. Small pieces of lignite are found. in very many wells in the drift. Occasionally a large piece is reported. One boulder, found by T. R. Shimmin in western Dickey County, contained a large percentage of silver, and several citizens of western La Moure County report samples of drift rock in Raney Township that yielded gold and silver. These were doubtless plucked by the ice from ore-bearing ledges in Canada. Their occurrence in western La Moure County led to much excitement among early settlers, who drove in from all directions and staked out claims on nearly all the land in secs. 25 and 26, T. 135 N., R. 66 W. It was here that the big masses of unbroken shale, noted above, were discovered. In the southwestern part of sec. 35, Clement Township, Mr. Denning found a pocket of sulphurous material 5 inches in diameter, 12 feet below the surface. Pieces of coal were also encountered in making his well.

The drift of the morainic hills contains a larger proportion of boulders, as well as of sand and gravel, than that of the smoother tracts, although some of these 'tracts have many boulders sprinkled over them. The rough morainic tract, 3 miles wide, on the Coteau 
front in Dickey County is covered with countless boulders, in places so closely set as almost to constitute a pavement. Many hills in the Oakes moraine are also very bouldery.

Deposits of assorted drift consisting chiefly of sand and silt but including also a large proportion of clay and gravel form small knolls scattered over the area, a system of eskers extending south from Edgeley, and the deposits of glacial Lake Dakota.

\section{CONFIGURATION OF THE DRIFT AND OF THE BEDROCK}

In the area as a whole the surface of the drift is very uneven. This irregularity is due in part to erosion, in part to inequality of distribution, and in part to unevenness of the eroded surface of the Pierre shale, upon which it was laid. Before the deposition of the drift there was a relief of at least 400 feet in the area. Records of wells in the eastern half of the area indicate that the general preglacial topography was similar to that of the surface of to-day in that there was a river valley with a general north-south axis. The river itself is believed to have had about the position and course of the present James River, at least in the time immediately preceding the last advance of the ice. In preglacial time also the area may have drained to the south and east. South of T. 132 N. and east of $R$. $62 \mathrm{~W}$. the drift is about 200 feet thick, and the altitude of the bedrock is 1,100 to 1,200 feet above sea level. North of this area the exact altitude of the shale surface was not determined, for two reasons - the drift is 300 to 400 feet thick and is penetrated by the artesian wells only; the drift below the weathered zone is very similar in color and hardness to the underlying shale, and the line of separation is seldom distinguished by the drillers. The east side of the broad preglacial valley lies east of the area under discussion and may possibly be continuous southward with the west slope of the Coteau des Prairies. One bench of its western slope is probably found in R. $63 \mathrm{~W}$. and the eastern half of R. $64 \mathrm{~W}$. The shale surface rises much more rapidly toward the west in these ranges than the present surface of the drift. This rise is about 300 feet in 8 or 10 miles, though much of it is localized within a few miles, making the slope abrupt in that part of its extent. This rise may be the southern extension of a possible shale escarpment of the Coteau du Missouri farther north, though lacking as a covering the great terminal morainic features, which in this latitude are 6 to 8 miles farther west.

The Coteau du Missouri has repeatedly been described as being underlain near its eastern front by an abrupt shale escarpment 300 to 400 feet high, compared with which the drift forms a relatively thin deposit. If the records of the comparatively few deep wells 
in the Coteau can be relied upon, however, there is little or no increase in altitude of the surface of the shale at or west of the Coteau front in this area. In the Edgeley quadrangle there is, so far as known, no such shale escarpment in the Coteau. Rather the relief of the Coteau above the plain immediately to the east seems to be due almost entirely to a great mass of drift, which has accumulated to a thickness of 100 to 480 feet. This is clearly indicated in the region north of T. $131 \mathrm{~N}$., where, it is reported, the shale was encountered in some recently drilled wells at depths ranging from 100 to 480 feet. The general altitude of this district is 2,000 feet above sea level; the outcrop of the shale south of Edgeley is at an altitude of 1,520 to 1,550 feet. South of this area the deepest wells end in drift at various depths down to 188 feet. Wells some miles west of this area indicate the same conditions, and if there is any shale escarpment under the Coteau in this latitude it is farther west in Logan and McIntosh Counties. However, it is doubtful if there is any shale escarpment along the Coteau front in the southern half of North Dakota. This structure of the Coteau du Missouri is similar to that of the Coteau des Prairies as found in southwestern Minnesota by Hall and Meinzer, ${ }^{6}$ who state that the plateaulike elevation is not entirely of preglacial origin but is capped by a heavy drift deposit.

\section{WISCONSIN DRIFT}

GENGRAL FEATURES

The surface features of the Western Lake section of the Central Lowland, comprising eastern North and South Dakota, much of Minnesota, and north-central Iowa, are largely the result of glaciation. A lobe of the Keewatin ice sheet advanced southward up the Red River Valley and spread westward into and extended across and down the James River Valley at the Wisconsin stage of glaciation. (See fig. 5 ) This region also undoubtedly received deposits from farlier extensions of the ice as well as the later one. The drift deposits comprise terminal moraines, till sheets, eskers, outwash, and glacio-lacustrine sediments. They were formed from material plowed up or plucked from the rock ledges and carried along by the moving ice. The till sheet probably accumulated chiefly by lodgment beneath the advancing glacier. When a warmer climate gradually returned the ice front was halted and melted backward. The outer terminal moraine consists of the drift deposited at the limit of the ice advance. The successive concentric inner moraines were formed about the ice margin and mark positions of halt of the retreating glacial front.

\footnotetext{
${ }^{6}$ Uall, C. W., Mejnzer, O. E., and Fuller, M. L., Geology and underground waters of southern Minnesota: U. S. Geol. Survey Water-Supply Paper 256, pp. 26, 27, 36, 37, 1911.
} 


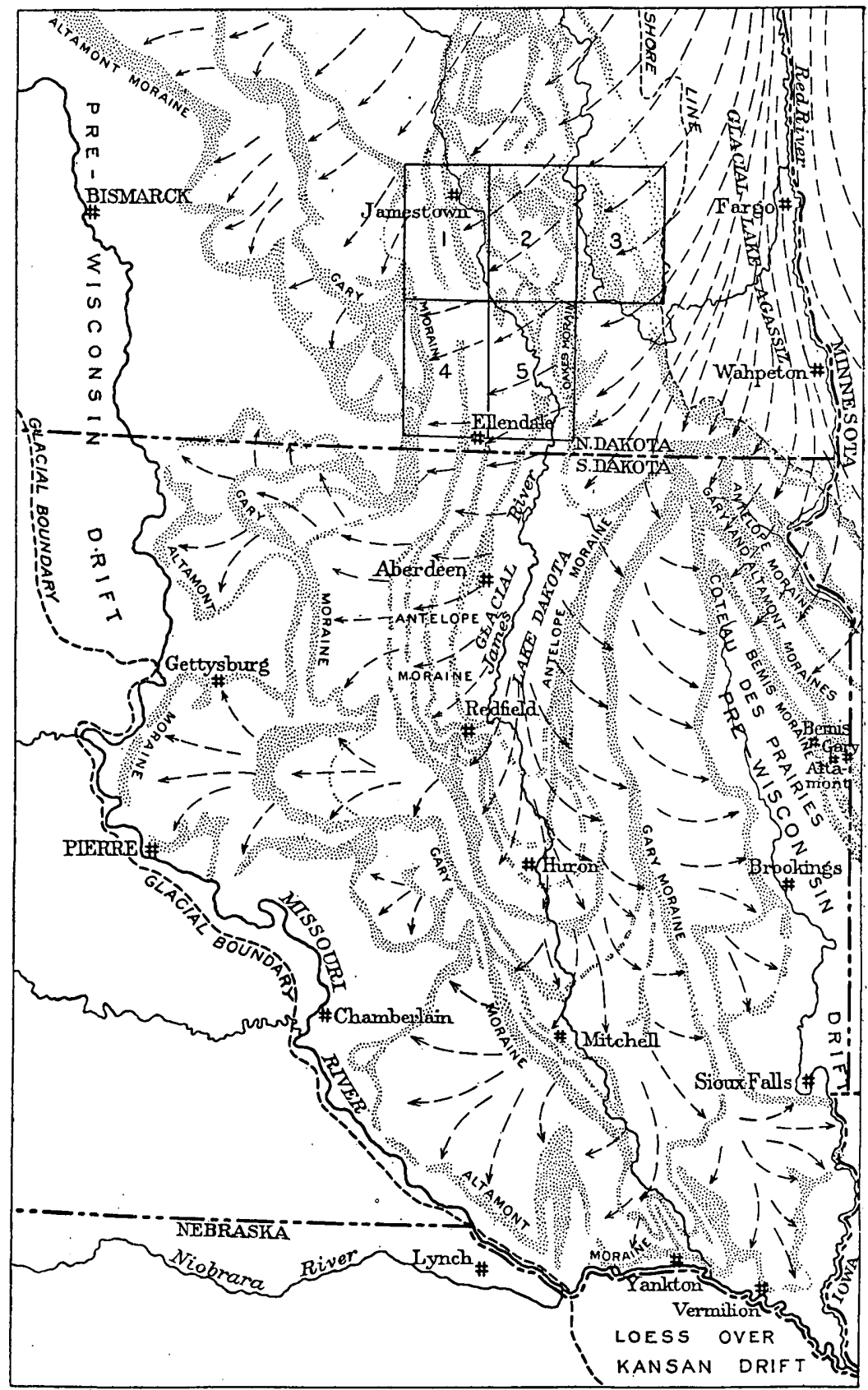

Figure 5.-Sketch map showing southwestern limit reached by the Pleistocene icesheets and the distribution of moraines of the Dakota glacial lobe of the Wisconsin stage of glaciation. (Compiled largely from Todd, Upham, Leverett, and others.) Numbered rectangles indicate location of quadrangles (1, Jamestown ; 2, Eckelson ;. 3, Tower ; 4, Edgeley ; 5 , La Moure) 
The pre-Wisconsin glacier is believed to have extended 20 to 60 miles beyond the present course of Missouri River in North Dakota but not so far in South Dakota. The Missouri flows not very far outside and roughly parallel to the Altamont moraine, which marks the limit of the Dakota lobe of late Wisconsin glaciation. The Coteau des Prairies stood as a wedge-shaped barrier at the Wisconsin stage between two broad open troughs that divided the Keewatin glacier in northeastern South Dakota, causing one lobe to move southward as the Dakota Valley glacier and deflecting the other to the southeast down the Minnesota Valley and thence into north-central Iowa. The names of the outermost three moraines of the Dakota lobe are taken from the towns of Altamont and Gary, S. Dak., on the east side of the Coteau, and the Antelope Hills. The Altamont moraine ${ }^{7}$ loops about the head of the Coteau des Prairies in a long reentrant, as shown in Figure 5. The later moraines were formed within and generally parallel to the Altamont moraine along lines where the ice front stood for any considerable period of time. Thus the Gary moraine, the several members of the Antelope morainic system, and the Oakes moraine were produced in succession, separated by smooth till plains, over which the ice margin retreated comparatively fast.

The valleys of several of the principal rivers of the region contain broad level plains that represent floors of extinct glacial lakes; and into these plains the rivers have cut their present channels. These lakes were formed along the southern margin of the melting glacier. In the valleys of Red and Souris Rivers they were caused by ice blocking the outlets of streams that had a general northerly course, but in the valley of the southward-flowing James River the lake was probably due to a constriction back of which the rapidly accumulating water ponded.

\section{ALTAMONT AND GARY MORAINES}

In the western part of the Edgeley quadrangle the Altamont and Gary moraines, the first and second Wisconsin moraines of the Dakota lobe, are massed together, occupying an area 3 to 10 miles wide. The Altamont moraine (fig. 5) doubles back eastward 70 miles from Missouri River in a great reentrant, whöse head just reaches into the southwestern part of the area under discussion. It certainly covers at least the southwestern townships, Tps. 129 and 130 N., R. 66 W., and for 8 or 10 miles farther north the Gary moraine coalesces with it, producing the roughest topographic features of the area. The rugged morainic hills are so massed together

? Leverett, Frank, What constitutes the Altamont moraine: Geol. Soc. America Bull:; voi. 33, pp. 102-103, 1922. 
that it is impossible to differentiate clearly the two moraines. In this rough area, which is 9 miles wide and 15 miles long, the hills are as much as 100 feet high, and many are thickly sprinkled with boulders. (See pl. 5, A.) Thence northward for 20 miles nearly to the north line of the Edgeley quadrangle the more subdued features belong to the Gary moraine. Several high ridges of the Altamont moraine extend westward beyond the limits of the quadrangle, and these are separated by comparatively level valleys, which drain to the west or southwest. Although the topography along the northern half of the portion of the Gary moraine lying in this area is very subdued, stronger features set in 2 to 4 miles farther west. Nearly the whole of Logan, McIntosh, and McPherson Counties has a rugged surface due to the Altamont and Gary moraines. In fact, the greater part of the Coteau country is marked by massive morainic. ridges 50 to 150 feet high, running in various directions and separated by depressions 1 to 10 miles or more wide.

The eastern part of the rough area in Dickey County, just described, and probably the whole of the more subdued belt farther north forms the head of a second great morainal loop or reentrant similar to and embracing within its arms the great loop of the Altamont moraine. From this reentrant the Gary moraine extends northwestward, on the one hand, from the Edgeley quadrangle through Logan and Kidder Counties toward Missouri River, and continues southwestward, on the other, about 20 miles into McPherson County, S. Dak., where it turns sharply west, parallel to the Altamont moraine, and extends within about 15 miles of the Missouri in Campbell County. The Gary moraine stands out boldly on the eastern flank of the Coteau in R. 65 W., and from this locality the surface drops 400 feet to the flat till plain on the east. In Dickey County and in the small area at the north line of the quadrangle designated "strongly morainic" on the map, besides the knolls that stand 15 to 50 feet above the general Coteau, the surface is cut by many sharp, deep gulches which drain portions of the upland eastward to Elm and Maple Rivers. This narrow belt, in common with the steeper Coteau slope just to the east, is so rough as to be entirely unfit for cultivation, though the numerous springs help to make it a fine grazing tract. In Tps. 133 and $134 \mathrm{~N}$. and the northern two-thirds of T. $132 \mathrm{~N}$. the moraine is very subdued in relief and contains a narrow intermorainic area in the center of R. $66 \mathrm{~W}$., which has many sloughs, small marshes, meadows, and large tracts whose drainage by artificial means presents a very difficult problem. The imperfect natural watercourses lead to the northeast, down the Coteau slope.

The Altamont and Gary moraines include many undrained tracts, which range in area from a few acres to several square miles. In 


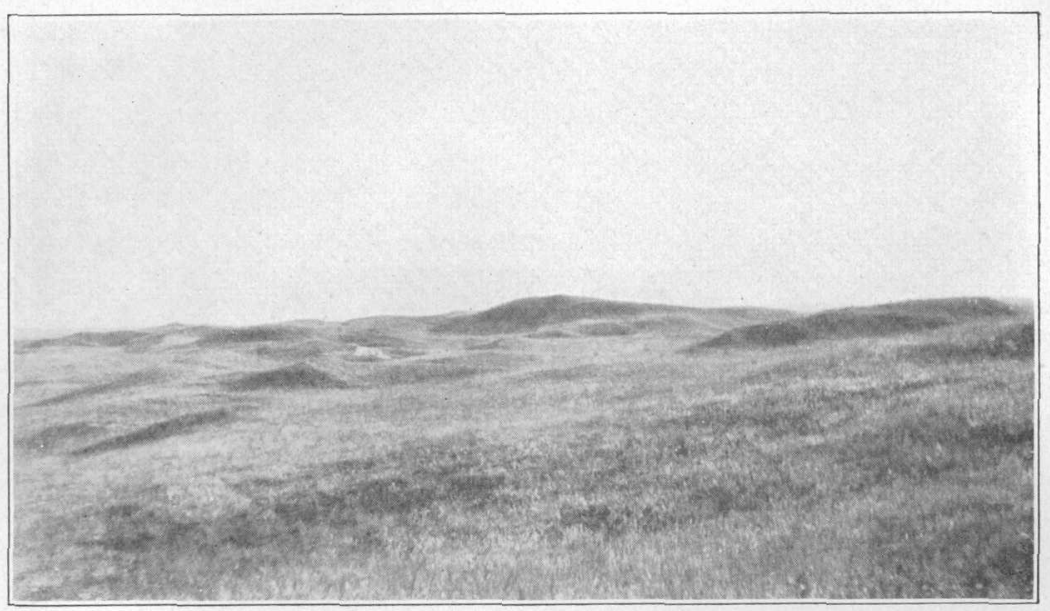

A. TERMINAL MORAINE ON COTEAU DU MISSOURI

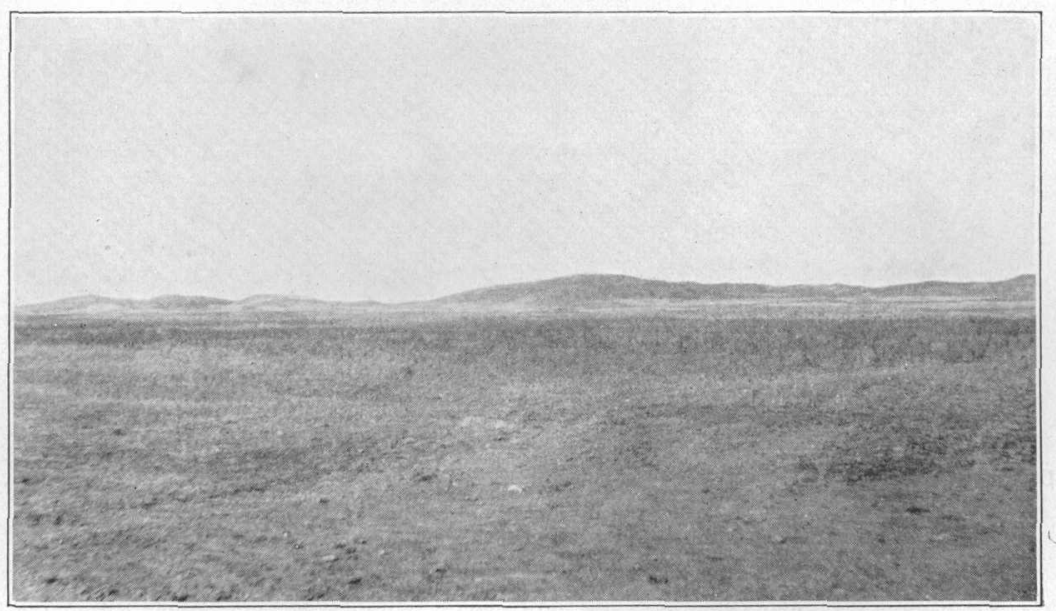

B. OAKES MORAINE, A RECESSIONAL MORAINE

Glacial Moraines 
years of greater precipitation these tracts contain small lakes or marshes, which, unless spring-fed, evaporate in dry periods, many of them leaving alkali-incrusted beds or a sparse growth of salt grasses.

The material composing the drift in the Altamont and Gary moraines is much coarser than that of the remainder of the area, containing much more sand and gravel, especially in an area 3 miles wide extending 20 miles north from the southwest corner of the Edgeley quadrangle. Some of the highest hills of the region are kames, or gravelly morainic knobs, of which fine examples are seen in secs. $26,27,29$, and 30, T. 131 N., R. 66 W., secs. $3,29,31,32,33$, and 34, T. 130 N., R. 66 W., and secs. 4 and 5, T. 129 N., R. 66 W. The town-line road on the north side of secs. 4 and 5 is graded down 10 to 15 feet in good commercial sand and gravel. In fact, nearly the whole area of the above-named sections is deeply covered with sand or gravel. Similar conditions prevail far into McIntosh County, on the west.

That part of the Coteau du Missouri lying within the Edgeley quadrangle appears to be composed entirely of drift. None of the wells drilled in it, so far as known to the writer, reach the underlying shale at altitudes much higher than the exposures of shale south of Edgeley. It appears, therefore, that whatever definite shale escarpment there is beneath the plateau in this latitude must be west of the area here described. When the last ice sheet spread over this region, however, there must have been a great obstruction extending as far east as the southwestern part of the Edgeley quadrangle, for the great loop in the Altamont and Gary moraines shows that. the ice was prevented from extending as far west in this part of the region as it did either farther north or farther south. If the obstruction was not due to a high shale escarpment it must have been due to a great accumulation of drift. From this conclusion it seems probable that the larger part of the great thickness of drift in this belt must be of pre-Wisconsin age, and only the smaller part, though a considerable thickness, really belongs to the Altamont and Gary moraines.

\section{TILC PLAIN BETWEeN THE GARY AND ANTELOPE MORAINES}

The till plain extending from the base of the Coteau du Missouri to the outer moraine of the Antelope morainic system, 6 to 8 miles east, is almost featureless and has a uniform eastward slope of 25 to 30 feet to the mile. In Tps. 133 and 134 N., R. 65 W., where the Gary moraine is set back from the eastern crest of the Coteau, there is a comparatively smooth tract which descends at the rate of 60 to $6147-29-3$ 
90 feet to the mile to the flat prairie land. Owing to the fact that they receive the spring-time wash from the Coteau, some of the coulees are deeply cut along parts of their courses. The erosion that has cut the deep gashlike ravines in the whole Coteau front has caused great quantities of sand and gravel to be deposited within the first mile or two at its base. The drainage is naturally good over the plain except along the border of the Antelope morainic system, where it is partly blocked. This has given rise to many alkaline or "gumbo" tracts.

\section{ANTELOPE MORAINIC SYSTEM}

Outer moraine.-The Antelope morainic system is represented in the Edgeley-La Moure area by two members, each composed of low swells or subdued hills. The western or outer member is made up of more or less disconnected hills or ridges and flattens out entirely north of Edgeley. These hills are scattered over an area 5 or 6 miles wide and interspersed with many large level tracts. They range from gentle swells or low mounds to hills 15 or 20 feet high. For the most part they are of subdued form, though in places, notably in the north-central part of T. 132 N., R. 64 W., the southwestern part of T. 131 N., R. 63 W., and the eastern part of T. 130 N., R. 64 W., they have the sharp expression of moraines that have never been overridden by ice. The last two areas named contain several gravelly kames, the largest of which are indicated on the map. It is in the smoother intermorainic tracts that the Pierre shale is exposed in the ravines. The general easterly drainage of the region is partly blocked by the moraine, and many of the smaller tributaries of Elm and Maple Rivers are forced to unite and find a common passage.

Inner moraine.-A mild morainal belt extends from north to south. across the La Moure quadrangle, principally in Rs. 60 and $61 \mathrm{~W}$. Although this moraine has been correlated in the Jamestown-Tower folio with Upham's Kiester moraine of southern Minnesota, the results of the present survey seem to indicate that it is to be correlated with one of the inner members of the Antelope morainic system as described by Todd in the Aberdeen-Redfield folio. (See fig. 5.)

The main portion of this moraine, that in $R_{s .} 60$ and 61 , is somewhat peculiar in that it is, in large part, marked not so much by piledup morainal hills or ridges as by a belt of depressions. This character is in places so manifest as to give rise to the suggestion that the moraine lies along the line of a partly filled older valley. The moraine has no distinct relief above the plain on either side. James River may owe its location from the big bend north of Oakes to La Moure or Grand Rapids originally to such a line of depressions with intervening sags. Twin Lakes lie in one of the major depressions, and in a period of wet years several others develop lakelets, ponds, 
or marshes. West of Grand Rapids, in R. 62 W., is a morainal tract, subdued in character but yet more strongly morainal in form than the portion just described. The moraine mapped in Gladstone Township (T. 133 N., R. 60 W.) is very similar to that west of James River. It has in addition several gravelly kames. The roughest topography of the moraine is found in Dickey County, along the east side of Tps. 130 to 132 N., R. 61 W. Here the moraine may have been laid at the base of a minor escarpment, cut perhaps in pre-Wisconsin time, that extends due south from the big bend of James River in central Wright Township. Its position is marked on the map by the 1,400-foot contour. Numerous large sags and hollows in this portion trend north and south. In Yorktown and Wright Townships the sags contain many hills 10 to 25 feet high.

TILI. PLAIN AND ESKERS BETWEEN THE OUTEP AND INNER MORAINES OF THE ANTELOPE MORAINIC SYSTEM

From the outer moraine of the Antelope system a nearly level plain 10 to 15 miles wide extends eastward to the inner moraine. North of Edgeley a till plain extends unbroken from the rough Gary moraine, in the western part of Tps. 134 and 135 N., R. 65 W., 20 miles east to the inner moraine in the eastern part of R. $62 \mathrm{~W}$. This almost featureless tract is cut by the southeastward-trending ravines of the intermittent Maple River and Cottonwood Creek and by the shallow abandoned postglacial drainage channels in $R$. $62 \mathrm{~W}$. The drift underlying the plain is for the most part very heavy in texture, consisting of 1 foot to 400 or 500 feet of clay with minor seams of sand and gravel, and some boulders are intermingled with the other materials or scattered over the surface. An area of several square miles where the soil is more sandy is found around Duane, in Elden Township.

On the west side of this plain are sinuous ridges or eskers trending southwest and leading up to the moraine. The longest is about 6 miles in length. It starts at the north line of sec. 5, T. $132 \mathrm{~N}$., R. $63 \mathrm{~W}$., with two small branches, which independently cross into sec. 8, where they unite. From this junction the esker takes a devious course to the center of sec. 30 of the same township, ending at a low morainic tract. Its course in places is interrupted by small kames or knolls, and it is believed to include some till knolls or ridges. Much of the material composing this esker is of unusually fine texture, being largely silt or clay. Other sections yield sand or fine gravel. It is a persistent ridge, 3 or 4 rods wide and usually about 8 to 10 feet high except where it develops a kameliks enlargement, which may be 15 feet high. 
Eskers more typical in composition and structure and of greater eross section are found southeast and north of Edgeley. A finely developed composite system of branching eskers is found in western Willowbank Township. The main branches arise in secs. 5, 8, and 9, converge in sec. 17, and end at the moraine in sec. 30. Much of the original deposit has been eroded away by the tributaries of Maple River, and several kames form parts of the ridge, which ranges from 5 to 15 feet in height within short distances. It also varies greatly in composition but has a higher percentage of sand and gravel than the esker first described. It is most typical in form in sec. 17 and the northwestern part of sec. 8. The esker $1 \frac{1}{2}$ miles east of Edgeley, in secs. 1 and 12, T. 133 N., R. 64 W., is about a mile long, very uniform, and of typical shape and structure. It is 8 to 10 feet high and 3 to 5 rods wide. One open pit beside the road shows stratified sand and gravel. Short eskers are found in the northern part of secs. 34 and 35, T. 134 N., R. 64 W.; the one in sec. 34 is three-quarters of a mile long and 5 or 6 feet high. Several small kames are distributed over the area to the north.

Several short eskers are found in the western part of Cottonwood Township (T. 133 N., R. 61 W.). One on the bluff overlooking James River in sec. 28, Grand Rapids Township (T. 134 N., R. 61 W.), was partly removed by the Indians in constructing one of the numerous burial mounds of this locality. The location of this Indian mound and others in Roscoe and Grand Rapids Townships is indicated on the map.

TILL PLAIN EAST OF THE INNER MORAINE OF THE ANTELOPE MORAINIC SYSTEM

East from the inner moraine of the Antelope morainic system an undulating till plain extends 2 to 7 miles. From the north line of T. $131 \mathrm{~N}$. northward it is limited on the east side by the Oakes moraine, and from that line southward it is bounded by James River Valley and the silted floor of glacial Lake Dakota. The drift beneath this plain is about 200 to 500 feet thick. Its texture is generally heavy, except in that portion of La Moure Township south of the Fargo branch of the Union Pacific Railroad, which is covered with a thin veneer of fine sand. This sand is several feet thick in the center of this area. It continues down over the river bluff into James River Valley on the northwest, where it was blown by the wind.

\section{CORRETATION OF THE MORAINES}

In discussing the successive positions of the retreating ice front $\mathrm{Upham}^{8}$ states that

The Waconia moraine appears to be merged with the two preceding Elysian and Kiester moraines in the conspicuous belt of drift hills that extends from

${ }^{8}$ Upham, Warren, The glacial Lake Agassiz: U. S. Geol. Survey Mon. 25, p. 143, 1896. 
the line dividing South and North Dakota northward between Straubville and Crescent Hill, between Nicholson and Oakes, and along. the east side of Bear Creek, to the southeast part of T. 135, R. 59. Thence it runs again northward through the west part of T. 136, R. 59.

This statement does not exactly express the relations found during the present investigation. The main moraine on the east side of Bear Creek extends northward to the Sheyenne Valley on the east side of Sand Prairie, in the southwestern part of the Tower quadrangle. This moraine is correlated by Willard ${ }^{9}$ with the conspicuous moraine on the east side of the Sheyenne River Valley farther north in the Tower quadrangle, to which he applied the name Fergus Falls moraine. There is, however, a serious question as to the propriety of applying that name to this moraine or to any moraine in the $\mathrm{La}$ Moure quadrangle and thereby indicating correlation with Upham's Fergus Falls moraine of western Minnesota. If the mapping by Willard in the Jamestown-Tower folio is accepted, the correlations by Upham seem to require some modification. The morainal deposits in Black Loam Township (T. 135 N., R. 59 W.) extend northward on the west side of Sand Prairie and join a conspicuous moraine in the Eckelson quadrangle, to which, following Upham, Willard applied the name Waconia. The present investigation shows that these deposits continue southward with some discontinuity through R. $59 \mathrm{~W}$. to a point southeast of Glover, in T. 132 N., R. 59 W., and there they appear to merge with or pass under the big moraine east of Bear Creek. The next moraine west of this in the La Moure quadrangle is probably the inner moraine of the Antelope morainic system. It may be, therefore, that the moraine called Waconia by Willard, which passes east of Valley Junction and Glover in R. $59 \mathrm{~W}$., is really the Kiester moraine of Upham. In La Moure and Dickey Counties it consists for the most part of rolling drift knolls, as subdued as the Antelope moraines. Both may perhaps have been smoothed out by a readvance of the ice. In Ovid Township the narrow ridge has not great relief but has many sharp hills, many of which are gravelly kames.

\section{OAKES MORATNE}

As stated above, a conspicuous moraine extends north and south along the east side of the La Moure quadrangle. Pending further study of the moraines of southern Minnesota and northeastern South Dakota, it is not now clear just what correlations are to be made and what Minnesota names, if any, should be applied in this area. Under the circumstances the application of a local name may best serve the purposes of this report. The name Oakes is therefore proposed for the conspicuous moraine lying east of the village of that name

- Willard, D. E., U. S. Geol. Survey Geol. Atlas, Jamestown-Tower folio (No. 168), 1909. 
and extending thence northward on the east side of Bear Creek. The main Oakes moraine, though not so rough as parts of the Altamont and Gary moraines, has sharp features with boulder-strewn surfaces. Extending into the northeast corner of the area from a direction a little east of north, the west front of the moraine continues nearly due south to the vicinity of Oakes and thence bears southeastward into Sargent County near the northwest corner of Jackson Township. It occupies an area half a mile to $31 / 2$ miles wide in the La Moure quadrangle, though most of the moraine is in the area on the east. The Oakes moraine has a relief of 30 to 40 feet above the till plain and 100 feet above the Lake Dakota floor on the west. (See pl. 5, B.) The relief between the rough stony hills which compose the moraine is nearly as great as that of the moraine itself. The moraine is several miles wide and has many short drainage ways opening into the valley of Bear Creek, which closely skirts it on the west to Bear Creek Township. Trending nearly due north, it extends 10 miles from this area to the west bluff of Sheyenne River. From the north line of Jackson Township the moraine extends southward about 20 miles in Sargent County, N. Dak., and into Marshall County, S. Dak., and loops back northeastward to the head of the Coteau des Prairies in the southeastern part of Sargent County. The Oakes and later moraines deposited between the head of the Coteau and the highlands on the northwest effectually blocked the large preglacial valley which is believed to have extended from the southwest through to Red River Valley along the course of Wild Rice River.

SAND PRAIRIE DEPOSITS

In the northeast corner of the La Moure quadrangle that portion of the plain below an altitude of 1,380 feet is as level as a lake floor and has a thin veneer of silt. This thickens toward the north boundary, where there is above the till at least 10 feet of stratified clay, sand, and gravel in places. This deposit is continuous at the north with the Sand Prairie tract of the Jamestown-Tower area and is probably due to glacial outwash into ponded waters. Along the west side of this area and in T. $134 \mathrm{~N}$. it grades imperceptibly into the till plain on the west.

The shallow glacial channel crossing the south half of Black Loam Township has a thin deposit of reworked glacial material a quarter to half a mile wide.

DEPOSITS OF GLACIAL LAKE DAKOTA

Glacial Lake Dakota occupied about 65 square miles of the southeastern part of the La Moure quadrangle, including all the area between the west slope of James River Valley, the Oakes moraine, 
and the east boundary of the quadrangle, also a narrow strip on the west side of. James River at the south. This strip and the islandlike area between the silted channels in western Riverdale Township are largely till, with a little silt forming a veneer in small areas. East of the eastern channel is a lacustrine or slack-water deposit of alternating strata of clay, silt, sand, and gravel, with sand predominating. This lake deposit is about 100 miles long, extending from a point 12 miles north of Oakes to a point about the same distance south of the latitude of Redfield, S. Dak. Its maximum breadth in South Dakota is about 25 miles. It stands everywhere about 1,300 feet above the sea. It is reported to range in thickness from a few feet at the north end of the area to 65 feet at Oakes. The deposit in South Dakota is described by Todd in the Aberdeen-Redfield folio as 5 to 35 feet thick and largely composed of loesslike silt.

As the ground water stands near the surface of this lacustrine deposit, very few wells penetrate to the till below. There are many driven wells, and many 3 to 12 foot holes were made by the writer with a soil auger. A 12 -foot section made by boring in the bottom of a sewer trench in Oakes showed sandy loam with yellow sandyclay subsoil, 15 inches; gray and brown sand with many seams of clay and muck, $103 / 4$ feet. The muck layers were half an. inch to $21 / 2$ inches thick and occurred at depths of 3, 6, and 9 feet. A little gravel was scattered throughout the deposit, and a very gravelly 6 -inch layer was found at a depth of $31 / 2$ feet. Many white limy concretions half an inch to an inch in diameter occurred at the 3-foot depth. Other holes and cuts yielded some magnesian limestone pebbles, many shale fragments of various sizes, and pink, yellow-gray, or black silt and sand. The sand is mostly quartz and is of various grades of coarseness. Many layers are loosely cemented by darkbrown iron oxide, others by lime, and all effervesce with acid, showing the presence of calcareous matter.

\section{TERRACES OF JAMES RIVER}

In the relatively narrow valley of James River are certain deposits in the form of bars and detached terracelike benches rising 10 to 70 feet above the present flood plain. The barlike forms consist largely of stratified sand or gravel. The benches are generally underlain by fine sand, though some are of glacial till eroded to their present form. All are shown and appropriately designated on Plate 2.

The sand and gravel are probably deposits of late Pleistocene time made by the much larger James River of that epoch, swollen by the waters from the melting glacier when the ice front stood at the position of the inner moraine of the Antelope morainic system, or farther east. In excavating its valley 100 feet down into the till, the 
river cut in some places and filled in others, according to the shifting of the main current. Slack water on the lee or downstream side of projecting headlands produced the barlike deposits seen in secs. 31 and 32, Grandview Township, secs. 5, 6, 26, 27, 34, and 35, Grand Rapids Township, and secs. 29 and 32, La Moure Township. The last named is much the largest, because Cottonwood Creek debouched into the James River Valley at this point, bringing additional sand and gravel, which was deposited as a bar in the slack water between the two streams. Smaller bars are found in different parts of the valley. Benchlike deposits of finer material were produced in protected places, as in southwestern Grandview, central Grand Rapids, west-central La Moure, eastern Wright, and southwestern James River Valley Townships. (See pl. 2.) Taken together these bars and terraces probably represent the bottom of the valley at the time James River was discharging into glacial Lake Dakota at a point 2 miles north of Oakes. The two large baylike reentrants in the side of the valley southwest of Glover may have been formed as intrenched meanders by two sharp bends of the down-cutting stream.

\section{RECENT SERIES}

Alluvium.-On the floor of James River Valley is a deposit of alluvium, formed after glacial Lake Dakota had been drained and James River had cut down to or below its present level. As the river seldom overflows at present it is possible that much of this deposit was made by the water from the waning ice while the glacier stood far to the north and while the James received the drainage from glacial Lake Souris. The flats range in width from a quarter of a mile to 2 miles. The material is for the most part fine sand and clay and extends to depths ranging from 25 feet at Grand Rapids to 50 or 60 feet at La Moure. The portion of Maple River Valley in Dickey County has a deposit of alluvium a quarter to half a mile wide.

Sand dunes.-Drought following the breaking of the prairie sod on the light sandy'soil of the Lake Dakota plain permitted the sand to be drifted by the wird in Riverdale and Lovell Townships, so that shifting dunes, 1 to 5 feet high, have been formed in many places. In secs. 19 and 30, Jackson Township, Sargent County, a small group of sand dunes 40 feet high has been formed. The same fine sand extends in lower dunes to the east over the lake floor and as a veneer over the Oakes moraine. Several miles to the southeast a range of high dunes is found. Sloughs or shallow drainage ways on the lake floor have a heavier soil closely bound with meadow sod.

Peat.-Two small deposits of peat 'occur in sec. 27, T. 130 N., R. $66 \mathrm{~W}$., one in the northeast corner along Crow Lake and one in the 
northwest corner. Each has an area of about 10 acres and is in places 6 feet deep. Turf is usually found on top and black peat beneath. It was used by early settlers as fuel. A growth of sedges, moss, and other plants covers the surface.

\section{GEOLOGIC HISTORY}

\section{CRETACEOUS PERIOD}

North Dakota in common with the Great Plains region generally was depressed in Cretaceous time and was covered by the advancing sea, which ultimately extended from the Gulf of Mexico to the Arctic Ocean and from the Rocky Mountains at least to the longitude of St. Paul, dividing North America into an eastern and a western continent. In the latitude of the Edgeley-La Moure area the sea must have been at least 800 or 900 miles wide from east to west. Over most of this region sedïments were deposited to an average depth of perhaps a quarter of a mile. The materials were brought in by great rivers from land areas that can not now be definitely located. The sediments were deposited on the eroded Archean, Ordovician, and Silurian rocks, at least along the west margin of the Red River Valley and thence eastward in southern Minnesota nearly to the position of Mississippi River. Upper Cretaceous rocks still underlie North Dakota except along the east side under the Lake Agassiz floor, whence they have been in part at least removed by erosion.

Dakota epoch.-At first the Cretaceous sea was shallow and may have been represented by brackish. water or by fresh-water lakes. In the shallow sea strong currents assorted and deposited coarse sediments. Abundant vegetation, including many dicotyledons that resembled present-day species, lived on neighboring lands. At least 500 species have been identified. Salt-water mollusks indicate true marine conditions for part of Dakota time. Marine conditions were fully established in the region of North Dakota early in the Benton epoch by a gradual transition, indicated by the fact that the Benton sediments, so far as known, rest conformably upon the Dakota sandstone, and these conditions continued in the area until near the end of the Cretaceous. The rivers of Benton time were muddy and transported much clay to the sea. The Niobrara sea was probably deeper, clearer, and freer of sediments, so that countless numbers of lime-secreting animals lived in its waters. Fossil evidence of life in the Pierre beds is almost lacking in the Edgeley-La Moure area, but the long duration of the sea is indicated by the thickness of its fine offshore deposits.

The Fox Hills, Lance, and Fort Union formations, developed in central and western North Dakota, were also, presumably, laid down 
in the La Moure area, but if so they have been almost or quite removed by erosion. The Fort Union has been reported as present just west of the Edgeley quadrangle ${ }^{10}$ and may possibly extend into it in the area where 400 to 480 feet of drift conceals the underlying formation, though the few deep wells dug in the region have afforded very little record of the formations penetrated.

\section{TERTIARY PERIOD}

\section{POST-CRETACEOUS - EROSION}

At the end of Fox Hills time and again at the end of Lance time the site of the former interior sea became land, as a result of sedimentation and perhaps also of regional uplift. A sea or lake floor that has long received the waste brought down by rivers from the surrounding land usually has a monotonously flat surface. Such was the region of North Dakota when it emerged from the Cretaceous sea.

After the deposition and uplift of the Fort Union beds erosion of the newly made land began on a grand scale. The ordinary agency of water flowing in rills, brooks, and rivers, assisted by the various processes of weathering, cut and carved the partly consolidated rocks formed in the earlier seas and lakes. Not only was the postCretaceous highland channeled by streams, but the erosion continued until the interstream ridges and uplands were removed and the whole region was reduced to a nearly uniform plain. Much of the Fort Union coal and other beds and, after the Oligocene uplift, nearly all the later sediments were swept away and transported to the seas. Perhaps 1,000 feet of these strata were removed from western North Dakota, and in the eastern part of the State some 500 to 1,000 feet of Cretaceous and Tertiary sediments were eroded and the region was probably reduced nearly to base-level.

Then an uplift of the region initiated the erosion cycle that produced the escarpment of the Coteau du Missouri and the Turtle Mountains and again wore down to base-level the region east of the Coteau, including most of the Edgeley-La Moure area. This plain extends eastward to the crest of the eastward-facing Manitob escarpment. The wearing down above the Manitoba escarpment probably occupied most of the Tertiary period. This erosion cycle was brought to an end by a further uplift, which gave rise to the erosion that carved out great river valleys, notably the Red River Valley below the Manitoba escarpment. In late Pliocene and early Pleistocene time 300 to 500 feet of Cretaceous, Silurian, and Ordo-

${ }^{10}$ Leonard, A. G., North Dakota Geol. Survey Sixth Bienn. Rept., map, p. 98, 1912. 
vician strata were removed in eastern North Dakota, as indicated by the height of the Pembina Mountains above the buried floor of this valley. The Turtle Mountains are a remnant of the higher level cut off by erosion.

\section{PREGLACIAI DRAINAGE OF THE DAKO'TAS}

The preglacial drainage of North and South Dakota was believed by Warren, ${ }^{11}$ Todd, ${ }^{12}$ and others to have been almost wholly to the northeast into the Red-Nelson river system, rather than mostly to the Missouri-Mississippi system, as at present. The course of the Missouri from the point where it turns south at Fort Stevenson, N. Dak., to its mouth was believed by Todd to date only from the glacial epoch. Leonard, ${ }^{13}$ on the other hand, finds that the valley at least as far south as Bismarck had been excavated to a depth of 100 feet below its present level before the advance of the pre-Wisconsin ice sheet, which extended across its course, inasmuch as this glacier partly filled it with glacial deposits or reworked glacial gravel. Todd held that the ancient upper valley may have drained northeastward to Souris River or eastward to the region of the James River Valley and thence to the Red River Valley. Likewise Heart, Cannonball, Grand, Moreau, Sheyenne, Bad, and White Rivers were believed by Todd to have flowed on northeast of their present mouths across the course of what is now the Missouri Valley and into the James River Valley. Todd believed that the waters of these united rivers, flowing northward, carved a great valley in the position of the James through South Dakota and southern North Dakota and discharged eastward at about the position of the present Wild Rice River into Red River Valley. There Cretaceous and Paleozoic rocks were eroded to depths of 300 to 500 feet below the Manitoba escarpment. If this is true, possibly the wedgelike point of the Coteau des Prairies in southeastern North Dakota and northeastern South Dakota may be the headland between and at the junction of two great northward-flowing tributaries of a master stream emptying into Hudson Bay. The eastern of these tributaries would have been a branch flowing. northwest from north-central Iowa through southwestern Minnesota to the sup-

${ }^{11}$ Warren, G. K., Corps of Engineers U. S. Army Ann. Rept., 1868, pp. 307-314; Sclence, new ser., vol. 39, pp. 263-274, 1914 ; Am. Assoc. Adv. Sci. Proc., vol. 33, pp. 381-392, 1884.

12 Iodd, J. E., The Pleistocene history of the Missourl River : Science, new ser., vol. 39, pp. 263-274, 1914.

${ }^{13}$ Leonard, A. G., Pleistocene drainage changes in western North Dakota: Geol. Soc. America Bull., vol. 27, pp. 295-334, 1916 ; U. S. Geol. Survey Geol. Atlas, Bismarck folio (No. 181), 1905 ; Pre-Wisconsin drift in North Dakota : Jour. Geology, vol. 24, pp. 528-532, 1916. 
posed junction. However, the preglacial drainage of the region requires further investigation before definite statements can be made concerning it.

\section{QUATERNARY PERIOD}

PLEISTOCENE , EPOCH

GLACIATION

The late Pliocene uplift continued into the Pleistocene epoch and was followed by the beginning of glaciation. A lowering of the temperature with larger precipitation in the form of snow resulted in a vast accumulation of ice over the northern half of North America. There were three main centers of ice accumulation and dispersion in Canada (fig. 4), one east and one west of Hudson Bay and one in the Cordillera. Upon these the ice accumulated in such great thickness that it spread in all directions. From the first two of these centers, either simultaneously or alternately, the ice invaded the northern United States until the country was glaciated as far south as Ohio and Missouri Rivers and in places even farther. The country was invaded several times by the ice. Periods of cold, in which the ice advanced far to the south, were followed by periods of warmth, when the ice melted back far to the north. In the mild periods plants and animals returned to the glaciated area. Rocks were weathered, and soils had time to develop but were swept away or covered by the next overriding ice sheet. The several stages of advance of the ice are named from States where the glacial deposits are well developed and are, in chronologic order, the Nebraskan or pre-Kansan, Kansan, Illinoian, Iowan, and Wisconsin stages. The last stage, at least, was characterized by minor fluctuations or substages of retreat and readvance of the ice front. The lithologic composition of the drift suggests that the ice which reached the Dakotas came each time from the Keewatin center, west of Hudson Bay. The Wisconsin ice sheet reached nearly to Missouri River in North Dakota, and the region 20 to 60 miles farther west suffered an earlier glaciation, but the age of the deposits left there has not yet been definitely determined. Although all the drift exposed at the surface in the Edgeley-La Moure area is of Wisconsin age, it is believed that there is considerable earlier drift buried beneath the Wisconsin drift.

The ice of the Wisconsin stage in the southwestern part of the Edgeley-La Moure area encountered an obstruction in the Coteau du Missouri so great as not readily to be overridden, although the ice extended farther west in areas both north and south. This obstruction made a great reentrant in the glacial front, as shown by the position of the Altamont moraine (fig. 5). The reentrant or 
morainal loop opens to the northwest from the South Dakota line in R. $66 \mathrm{~W}$., showing that the ice pushed in upon the upland from the northeast, east, and south. As a result a considerable thickness of drift was piled up. There is reason for believing, however, that a large part of the bulk of the Coteau du Missouri in the Edgeley quadrangle is a great accumlation of pre-Wisconsin drift, upon which the drift of the Altamont moraine was piled.

After a prolonged stand at the position of this moraine the ice front melted back an unknown distance. It may have retreated only to the position of the second or Gary moraine, or it may have retreated farther through a long series of warm or dry years and later readvanced to the position of its next long stand. During the Gary substage the ice front generally stood 5 to 20 miles inside the Altamont moraine. In some places, however, it stood so near and formed the Gary moraine so close to the Altamont that the two can not be differentiated. This was the case around the head of the reentrant described above, in adjacent parts of McPherson, McIntosh, and Dickey Counties. In the Gary substage the ice pushed southwestward upon the Coteau in T. 132 N., R. 66 W., but was held back somewhat by the high ridge west of Merricourt, so that a minor reentrant was produced. From the northwest side of this reentrant and from Logan County the ice front at length retreated until it extended more directly northward to the region of Raney Lake. During this time the water from the ice in this area drained to the west or southwest. Thence northwestward the front of the glacier extended through adjacent parts of Logan, Stutsman, and Kidder Counties.

After the Gary substage the glacier was melted back from the Coteau and made its next stand 6 to 8 miles farther east, at the outer moraine of the Antelope morainic system. This may have been but a temporary halt, as the moraine is low and discontinuous and not traceable north of Edgeley within the area under discussion. However, it should be noted that the moraine was formed at the base of a strong slope leading up to the foot of the Coteau and perhaps stood in water ponded along the ice front. The flow of drainage must have been southward along the glacial margin and may have largely flattened out or washed away the moraine. Although most of the evidence has been removed, the nature of the soil in certain silted tracts supports the conclusion that the tract between the Antelope morainic system and the Coteau constituted a broad drainage way for the melting glacier. Probably at first obstructions existed, causing slack water or even a iemporary lake to cover the tract. A deposit of gravel and sand 1 or 2 miles wide that lies along the base of the Coteau in Dickey County may owe its origin in part to deposition in such a lake and in part to wash from the Coteau. 
Well-defined streams flowing southwestward in tunnels beneath the ice produced the eskers in Rs. 63 and $64 \mathrm{~W}$. After abandoning the outer of the Antelope moraines the ice never again advanced to it, as is seen by the undisturbed condition of the eskers and kames.

The glacial lobe, which had also been shrinking away from the Coteau des Prairies in eastern South Dakota and shortening northward in the James Valley, was now only 40 miles wide south of the La Moure area and occupied only the central part of the valley, probably extending little farther south than the site of Huron, S. Dak. (See fig. 5.)

During the temporary halt at the inner moraine of the Antelope system the glacial drainage eroded the several channels now abandoned in R. 62 W. In South Dakota the ice lobe had narrowed to a width of about 25 miles. After a brief stand at the mild morainal belt east of Valley Junction and Glover the western front retreated to the east side of the La Moure quadrangle, where, during a prolonged stand, the Oakes moraine was formed. This retreat uncovered nearly all the James River Valley, and the Dakota lobe then extended but 15 miles into South Dakota.

\section{GLACIAL LAKE DAKOTA}

The ice now stood along the east side of James River. Great volumes of water poured down the James River Valley, and when the ice disappeared from the upper Sheyenne Valley water came from the Sheyenne channel as well. The lower Sheyenne Valley was covered with ice westward to a point about 9 miles north of the northeast corner of the La Moure quadrangle, at the northeast corner of La Moure County. The water from the upper Sheyenne cut across the low divide over Sand Prairie into Bear Creek, where it was further swollen by the drainage from the ice front at the Oakes moraine. James and Sheyenne Rivers received all the water from the ice in central North Dakota and farther north, probably including that from glacial Lake Souris. They united their floods in the broad depression of the James Valley, which extended south from a point about 4 miles north of Oakes. This basin is constricted 100 miles south of this point and obstructed 70 miles farther south by the quartzite ledge near Alexandria, S. Dak. It is possible also that the north end of this basin may have been slightly lower when the ice began to melt and rose later after the glacier disappeared at the north. The waters from the melting ice poured in faster than they could find egress, so that they flooded the valley for a width of 25 miles and produced a shallow lake known to geologists as glacial Lake Dakota. 
As the ice front withdrew northeastward from its stand at the Oakes moraine in South Dakota, the lake probåbly spread behind the moraine until it reached as far as the site of Nicholson, in Sargent County, N. Dak. At this point it received the waters of Sheyenne River, which then flowed due south through the Big Slough behind the Oakes moraine from the point where the present river turns east at Fort Ransom. In the Jamestown-Tower folio this ancient stream has been named Ransom River. Its abandoned channel is three-quarters of a mile to $21 / 2$ miles wide. The northeastward extension of the glacial lake continued as long as the glacier pressed snugly against the head and east slope of the Coteau des Prairies. Its outlet flowed over the low divide separating it from the James River Valley. As this divide at the State line was composed of sand and clay it was readily eroded. When the ice melted back from the Coteau des Prairies the water ponded behind the Oakes moraine found an outlet to the east. The flood plain of James River is now 350 feet higher than Red River, and a cut of about 25 feet would permit the drainage of the James through Wild Rice River into Red River. As the watershed between the Wild Rice and James Valleys is only 10 to 15 feet above the general level of the Lake Dakota floor, the glacial lake in Sargent County was probably confluent with Lake Dakota, unless the latter had previously been drained by the cutting down of its outlet by James River. The rapid cutting of the James, which had eroded its present channel before the removal of the ice from contact with the Coteau des Prairies, alone prevented the drainage of the upper valley of this river toward the east into Wild Rice River and the partial restoration of the preglacial drainage system.

When the swollen torrents of James and Sheyenne Rivers and Bear Creek poured in at the north end of Lake Dakota, the coarser sediments were deposited as sand and gravel around the site of Oakes. The deposits grow finer southward, and cream-colored silt lies to a depth of 5 to 35 feet over the floor in South Dakota as far south as Redfield. The surface of this deposit is nearly level and is a little more than 1,300 feet above the sea.

\section{JAMES RIVER VALIEY}

James River may have flowed in practically its present course before the Wisconsin stage of glaciation. Its valley must have been largely drift filled, though it had been pretty well cleared out by the time the ice withdrew from the Oakes moraine and the Coteau des Prairies. The inner moraine of the Antelope morainic system placed diagonally across its course was a great obstacle to erosion, and on that account the valley 'is much narrower in the western part 
of James River Valley Township. However, the stream, swollen by the rapidly melting ice at the north, readily cleared the valley. The terraces and bars described above were built in slack water. As the James River flood plain up to Grand Rapids is at about the same level as the Lake Dakota floor, slack water must have extended at least that far at one time. As the glacial flood waned the flood plain was abandoned. The statement applies also to the old channel in the western part of Riverdale Township, on the east side of an island-like body of land. The James has since cut down about 15 feet at Oakes and 25 and 45 feet east of Aberdeen and Redfield respectively.

\section{ECONOMIC GEOLOGY}

\section{BUILDING MATERIALS}

Sand and gravel.-Aside from glacial boulders, which are often used in foundations, sand and gravel are the only building materials in the Edgeley-La Moure area. The glacial drift and the old river terraces yield a large amount of sand fit for mórtar and of gravel for concrete and road material. The grade is not uniform, and the quality of some deposits is made poor by the presence of silt or shale, so that much screening is required. There are many especially good deposits in the bars and terraces of James 'River, few of which have yet been opened. Some of the largest and of the best quality are found in the bars in southwestern Grandview and northwestern Grand Rapids 'Townships, in secs. 16, 18, 34, and 35, Grand Rapids Township, sec. 12, Cottonwood Township, and secs. 7, 17, 20, 29, and 32, La Moure Township. Much of the sand of glacial Lake Dakota deposited around Oakes is coarse enough for use, but the lake silt generally is too fine to be of much value. Some minor banks along Maple River and Bear Creeks are valuable.

The second largest source of sand and gravel is in the ridges and hills described as eskers and kames. The greater number of these shown on Plates 1 and 2 contain some material of economic value. The coarse drift in Tps. 129 to 131 N., R. 66 W., contains much valuable sand and gravel, which is being used for road making. Many open pits are designated on the map. West of Merricourt the Soo Line has opened a large pit in the gravel wash from the Coteau. It is believed that considerable deposits will be found all along the slope in Dickey County.

In some parts of the area glacial boulders. are abundant. These may be used either for masonry or after crushing for road material. Many of the granites, schists, and gneisses give fine effects in exterior walls.

Brick clay and shale.-It is believed that some of the clay and shale may be used in the manufacture of rough brick and drain tiles. 


\section{SOILS}

The soils of the La Moure quadrangle are mainly of three textural types-silt loam, silt clay loam, and loam. The soil is generally fairly heavy and is underlain by a good clay subsoil that seldom develops very troublesome hardpan. Lighter sandy soil occurs in the upland areas of the western half of Tps. 129 to $131 \mathrm{~N}$., R. $66 \mathrm{~W}$., in 10 or 12 sections in the center of Elden Township, in that part of southeastern La Moure Township south of the Northern Pacific Railway, in all areas mapped as eskers and kames, and in a tract 1 to 3 miles wide lying at the base of the Coteau du Missouri in Dickey County. The soil of the James River Valley is generally rather light in texture. The soil of the Lake Dakota plain is for the most part loose sand or silt and requires careful management to prevent it being blown about. The soil of certain tracts, largely near the north end of the plain, is heavier and gives good yields. Most of the lake area in North Dakota is suitable only for grazing and meadow. The light soil and subsoil of the James River Valley and the lake plain are known as "warm" and "early" soils, and on account of the fact that the ground water stands within a few feet of. the surface they are better supplied with moisture and are more productive than one would suppose from their leached character.

Alkali is troublesome in only one large tract in La Moure and Dickey Counties, although many alkaline areas, containing from a few acres to a section, are scattered throughout the area. The largest alkaline tract comprises the eastern half of R. $64 \mathrm{~W}$., extending from the larger morainic ridge in central Albion Township northward to the similar ridge running east and west in southern T. $133 \mathrm{~N}$. The low-lying land extending on northward some miles past Edgeley also has much alkali. The alkali of this tract is due to the blocking of the natural eastern drainage by the outer moraine of the Antelope morainic system lying across it. Some sections are good, but much of this land is practically useless. Many sections will become valuable when the soil is properly treated. There are many sloughs and old lake and marsh floors in the Altamont and Gary moraines and the inner moraine of the Antelope morainic system which are undrained and have a large amount of alkali. In the James Valley there are some poorly drained tracts having a damaging amount of salts in the soil. The largest of these is found west of La Moure. Nearly all of the valley land can be drained, washed with water from the river, and entirely cured. The alkaline soils are locally known as "gumbo" and have a high percentage of sodium carbonate and calcium sulphate. In the poorest tracts the salts collect as a white crust on the surface. Shallow wells in many localities are affected by the salts. The water from hundreds of artesian wells in the area is 
allowed by their owners to run at full force all the time. Often there is no good natural drainage and the water is permitted to collect in depressions and form alkaline pools with large marshy tracts about them. The land thus covered is usually of the best, and in the aggregate the loss is very considerable. The same condition prevails throughout the artesian basin of the eastern Dakotas and is a fit subject for drastic regulation.

\section{WATER RESOURCES}

\section{WATER IN GLACIAL DRTFT}

A large part of the population of the Edgeley and La Moure quadrangles draws its water supply from shallow wells, which obtain water in the glacial drift in nearly all parts of the area. In the western part the depth to water is somewhat greater. In La Moure, in the James Valley, and in Oakes, on the Lake Dakota plain, water is obtained from inexpensive driven wells only 5 to 15 feet deep, almost every house in these places having one or two such wells. In most places east of R. $64 \mathrm{~W}$. water is found in sand or gravel layers in the drift at depths ranging from 10 to 150 feet, but in some localities, as in parts of Henrietta Township, supplies are found only at depths of more than 200 feet. On much of the Coteau du Missouri water is obtained with great difficulty, many of the early shallow wells having failed entirely. Some farms are supplied by springs, and many others north of T. $131 \mathrm{~N}$. have wells 100 to 480 feet deep, some of which penetrate the shale. These relatively deep wells on the Coteau are drilled, like the deeper artesian wells.

In many shallow wells the water is artesian to the extent that it rises in the well, though it does not flow at the surface. Five or six shallow wells overflow freely at the surface. Among the flowing wells that end in drift are the Ellison well, in sec. 29, La Moure Township, 31 feet deep; a well in sec. 6, T. 132 N., R. 60 W., 40 feet deep, both on the bank of James River; one each in secs. 22 and 23, T. 132 N., R. 59 W., 200 and 240 feet deep; the Eaton well, south of Ludden, 160 feet deep; and a well on the brow of the Coteau, in sec. 4, T. $130 \mathrm{~N}$., R. $65 \mathrm{~W}$. The Wirch well, in sec. 21, T. $130 \mathrm{~N}$., R. $66 \mathrm{~W}$., is made to flow by siphoning into a near-by ravine. The wells in which the water rises undoubtedly tap beds of sand and gravel that lie between relatively impervious layers and are fed from higher ground, many from near-by morainic hills. If the place of intake of the rain water is higher than the mouth of the well a flow may result.

Many of the dug wells are imperfectly curbed and are polluted by water from barnyards or cesspools. The careful farmer locates his well some distance from these sources of contamination and at a 
higher level. Even deep wells may be polluted by water that passes down outside the casing, and great care should therefore be taken to set the casing tightly in the earth.

The following are partial analyses of waters from wells at Edgeley that end in glacial drift or in shale and are between 15 and 25 feet deep:

Partial analyses of water from shallow wells in drift or shale at Edgeley, N. Dak.

[Parts per million; analyzed in December, 1913, by North Dakota State College]

\begin{tabular}{|c|c|c|c|}
\hline Owner & $\begin{array}{c}\text { Total } \\
\text { dissolved } \\
\text { solids }\end{array}$ & $\begin{array}{l}\text { Organic } \\
\text { and vola- } \\
\text { tile mat- } \\
\text { ter }\end{array}$ & $\begin{array}{l}\text { Chloride } \\
\text { radicle } \\
\text { (Cl) }\end{array}$ \\
\hline $\begin{array}{l}\text { Chas. J. Sturgeon } \\
\text { C. R. Ordney } \\
\text { W. S. Hancock } \\
\text { C. H. Shiels. } \\
\text { H. H. Cornwel1. }\end{array}$ & $\begin{array}{r}a 860 \\
\text { o } 625 \\
-1,240 \\
\text { d } 730 \\
1,620\end{array}$ & $\begin{array}{r}180 \\
2.5 \\
2.5 \\
80 \\
00\end{array}$ & $\begin{array}{r}60 \\
20 \\
514 \\
44 \\
586\end{array}$ \\
\hline
\end{tabular}

a Mainly sodium carbonate with traces of sulphate, calcium, and magnesium.

b Mainly sodium carbonate with traces of sulphate and calcium.

- Mainly sodium chloride.

d Mainly sodium carbonate.

The water in the flowing wells, as in most nonflowing wells that end in gravel and have a strong supply freely drawn upon, is of satisfactory quality. Water that stands in wells in contact with clay or shale for a long time, however, may become bitter with absorbed salts, as was clearly shown by a well in sec. 32, La Moure Township. When gravel was struck at 31 feet in this well the water rose rapidly to a level less than 4 feet below the surface. 'The well was not strongly drawn upon for some weeks, and the water became bitter and unfit for use. As the well was within a few feet of James River, in which the water stood 10 to 15 feet lower than in the well, the owner cut the bank below the level of the water in the well and started a flow. In a few days the water had lost its bitterness and, continuing to flow, remained good.

\section{WATER IN THE PIERRE AND BENTON FORMATIONS}

A few wells have flows from beds above the Dakota sandstone. Flows probably from sand layers in the Pierre shale were obtained 1 mile north of La Moure at a depth of 260 feet; at Grand Rapids at a depth of 125 feet, or 36 feet below the top of this shale; and at Oakes at a depth of 320 feet. Flow:s were obtained probably from the Niobrara or the Benton formation in the Dennison well in sec. 7, Port Emma Township, at 600 feet; in a well 11/2 miles northeast of Verona at 540 feet; in sec. 26, Elden Township, at 850 feet; in a well in sec. 30 , Henrietta Township, at 870 feet; in a 
well in sec. 3, Port Emma Township, at 800 feet; in the 2,000-foot well in sec. 29, Norway Township, at 1,300 feet; and in the Morse well, sec. 32 , T. 133 N., R. 60 W., at 536 feet. The natural flow of the Dennison well was 20 gallons a minute.

Flows from the Pierre, Niobrara, and Benton formations, like those from the glacial drift, are usually weak and are generally cased off by the drillers. This is done partly for the reason that the well is drilled by contract for a lump sum, and the farmer, fearing the upper flow may prove inadequate, demands that the Dakota sandstone be reached. It is believed that no records are made of many flows from upper strata. Occasionally a flow from the drift of water of superior quality and of volume quite adequate for the farmer's needs is shut off and lost, and the driller spends hundreds of dollars penetrating deeper strata, which yield only salty water. The farmer would do well to keep in touch with his driller and pay him adequately either to stop at a fresh-water flow, or, if it is feared that the supply is not of sufficient volume for all needs, to pipe it independently to the surface for use as far as it will suffice. This water generally does not contain so large an amount of salts as the water of the Dakota sands, much of which is objectionable for drinking and boiler use. Furthermore, the near-surface flow may actually outlast the deep artesian supply, especially in the western part of the basin, as it may have an independent source, whereas the deeper. wells reach a layer which is tapped by thousands of other wells and in which the pressure is being reduced.

Weak flows of muddy water are often struck within 20 to 200 feet above the base of the Benton shale. This water, commonly called the "mud flow" by the drillers, is generally cased off. It is possible that as the artesian supply further declines in years to come this muddy water may be filtered and used. The Jensen well, near Oakes, yielded a flow of clear water near the base of the Benton shale at a depth of 877 feet.

The 125-foot flowing well in the Pierre shale at Grand Rapids yields relatively good water. A sample examined in 1914 by the North Dakota State College was found to contain 1,015 parts per million of dissolved solids, of which the chloride radicle made up 176 parts.

In many wells a hard rock, termed the " 40 -foot cap rock" by drillers, is found just above the Dakota water-bearing stratum. In other wells such a hard layer is reported far up in the Benton shale. Early drillers were often stopped by this rock, and sometimes they spent several weeks in penetrating it. Drillers with more powerful machines are now experiencing little difficulty in drilling through it. 
WATER IN THE DAKOTA SANDSTONE

\section{SCOPE AND METHODS OF TESTING ARTESIAN WELLS}

Field work on artesian wells was begun by the writer in 1914 in La Moure and Dickey Counties and was extended to other areas in following years. In 1916 more intensive work was started on artesian wells in Stutsman County south of Jamestown. In 1919 and 1920 these wells and those previously studied in La Moure and Dickey Counties were again visited. Thus an investigation has been made of the artesian conditions in a belt extending from Jamestown to the South Dakota line along the 1,500-foot contour. In La Moure and Dickey Counties the belt examined was 10 to 12 miles wide and included the land lying between 1,470 and 1,700 feet above sea level.

Another belt of wells, which crosses this belt at right angles and runs from the 1,700-foot contour eastward down the slope from the Coteau to Ellendale and Monango and thence beyond Fullertown, was examined in detail. Wells in an extension of this belt east past Oakes were examined in a cursory way. The line was taken up again some 20 miles farther east, between Forman and Geneseo. In 1919 and 1920 wells were examined on a line extending northward through Sargent, Ransom, and Cass Counties, at localities near Milnor, Lisbon, Sheldon, Enderlin, Alice, Embden, and Buffalo, and from Buffalo eastward to Wheatland. In 1920 the Des Lacs deep well was visited, and some detailed tests were made on the artesian gas wells from Lansford to Newburg, in Bottineau County. Shallow drift wells were tested at Maddock, in Benson County, and at Jud, in La Moure County. The work in 1919 and 1920 was done as a part of work for the State of North Dakota on flood control, of which the writer was chief engineer. Only the data obtained for the Edgeley and La Moure quadrangles are given in this paper; data for other parts of the area of artesian flow in North Dakota can be found in a report published by the State. ${ }^{14}$

Before 1919 a small number of wells had been studied each year in great detail. This plan was changed because each year some of these wells became unfit to stand closed-pressure tests and others stopped flowing, so that the number of test wells became too small. To obviate this difficulty, in 1919 the number of wells on which flow tests were made was greatly increased. In 1920 a still greater number was added, and a good addition was made to the pressure tests, including those on a series of new wells near Ellendale and Monango-the Lind, Thorn, Fleming, Taylor, Gray, Whelan, and Fuller wells.

${ }^{14}$ Hard, H. A., Report to the Governor of North Dakota on flood control for the years 1919-20, 1923. 
A collection was also made of the $\operatorname{logs}$ of several hundred wells by interviewing owners and drillers, especially the Oakes Artesian Well Co., Mr. C. E. Turnbaugh, and Mr. Lee Herring, who generously made available the records of many wells in their files. In so far as possible the depth, diameter, original and later pressures, and flow were recorded, and all data having any interest were collected. These records were of great value in preparing this paper.

The equipment used for field work included pipe tongs, wrenches, pliers, plenty of extra couplings of various sizes to replace any found to be defective or rusted out or disturbed by making connections for testing, graphite and thick lead paints and rubber dam for joint wiping, a good steam-pressure gage with auxiliary, thermometer, quart, gallon, 2-gallon, and 10-gallon measuring vessels, rubber hose, wire, sounding line, and stop watch. It is usually most economical for two persons to work together on a well.

Permission was usually obtained before a well was tested. If the owner was at all unwilling or the pipes were rusted so that disconnecting would complete their ruin and cause inconvenience to the owner, no test was made. If the rusting of parts was not extensive, the rusted parts were removed and new couplings or pipe installed, and the well was then tested and left in good repair. The public has thus acquired valuable information, and the farmer has received a little gift of plumbing.

The tests of the wells consisted of measurement of flow, open and closed pressure where feasible, temperature of the water, and the flow of gas if any.

For flow tests a vessel of known volume was held so as to catch the entire flow of the well for a fixed time, noted with watch in hand. A good steam gage with auxiliary was attached for pressure tests. After the "open" pressure was taken the well was slowly turned off to avoid possible injury, and the closed or actual pressure was read every few minutes till it became constant. This took from half an hour to an hour for most wells, longer for a few others. Some tests were run all night, for two reasons-to determine possible variation in a 12-hour test, and to demonstrate that a well will not cease flowing if shut entirely off. At every well the valve was carefully turned on in the morning and the water came as usual. It gave much satisfaction to many farmers to know that the water could be turned off to prevent needless flooding of valuable land and the making of a foul-smelling mud hole near the house or barn.

In February, 1923, the information in regard to decline of artesian pressure was brought to date by O. E. Meinzer, geologist in charge of the ground-water division of the United States Geological Survey, who sent questionnaires to owners of artesian wells in a belt 
along the western border of the area of artesian flow. This was accomplished through the hearty cooperation of the postmasters at Edgeley, Monango, Ellendale, and Forbes. In July and August, 1923, several days were spent in the area with Mr. Meinzer, H. E. Simpson, water geologist of the State Geological Survey of North Dakota, and C. E. Turnbaugh, an experienced well driller who was engaged by the State Geological Survey to inspect artesian wells in order to stop the illegal waste of artesian water. Through cooperation between the State and Federal surveys Mr. Turnbaugh, in November and December, 1923, examined practically every artesian well in the Edgeley quadrangle and adjacent parts of the La Moure quadrangle-both those that were still flowing and those that had ceased to flow. The results of the data obtained in 1923 by correspondence and in Mr. Turnbaugh's survey are discussed by $\mathrm{Mr}$. Meinzer on pages 57-74.

\section{POSITION OF WATER-BEARING BEDS}

The importanice of artesian water in this region is shown by the fact that in 1915 there were between 600 and 700 flowing wells in the Edgeley and La Moure quadrangles. (See pls. 3 and 4.) The main supply of artesian water comes from the Dakota sandstone. This formation underlies the greater part of both North and South Dakota, including the Edgeley-La Moure area, where it has a low, general southwesterly dip. The thickness, extent, and character of the Dakota sands are discussed on pages 14-15. The stratum in the Dakota sandstone that gives the first artesian flow is usually within 50 feet of the top of the formation. It ranges in altitude from somewhat less than 200 feet above sea level at the west side of the Edgeley-La Moure area to more than 500 feet at the east side. As shown by the artesian-water maps (pls. 3 and 4), the depth to this stratum ranges from about 900 feet to more than 1,500 feet. In a few localities, as in the northeastern part of Kent Township (T. 130 N., R. 61 W.), this upper stratum yields no flow. Where the head is sufficient the flow from the first sandstone is strong and appears promptly when this stratum is penetrated. In some wells the flow from the first standstone is very weak and is cased off. This occurs where the sandstone stratum is thin or very fine grained. In some wells the pressure and flow increase continuously with depth, but usually two or more separate flows are encountered. As many as seven successive flows have been obtained in drilling one well, the water-bearing beds being separated by impervious "hardpan" of shale or dense sandstone. Successive artesian layers are usually marked by sudden increase in flow. Water from the second and third artesian horizons usually has a larger pressure than that from the first. 


\section{ARTESIAN CONDITIONS}

The Dakota'sandstone crops out on the flanks of the Black Hills, Big Horn Mountains, and other mountain ranges. From the mountains this sandstone dips to the east and by many wells is traced under the plains of North and South Dakota, where it gradually rises within a few hundred feet of the surface and supplies water to thousands of wells. The sandstone cropping out in the mountains catches the rain and absorbs water from streams flowing over it. The water thus collected is held within the porous sandstone by the nearly impervious formations that lie above and below it and moves far out under the plains. As the intake on the mountains is 3,000 to 6,000 feet above sea level and the original area of artesian flow in the Edgeley and La Moure quadrangles was everywhere less than 1,800 feet above sea level, there was ample difference in altitude to produce artesian pressure.

The head of water in a flowing artesian well, in feet above sea level, can be calculated by multiplying the pressure at the mouth of the well, in pounds per square inch, by 2.3 and adding the result to the altitude of the well mouth. The artesian- water must percolate a long distance through sandstone to get from its areas of intake to the Edgeley and La Moure quadrangles and to the rest of the great area of artesian flow in North and South Dakota, and much of its head is dissipated in overcoming the friction of the sandstone throughout its long journey. As the artesian 'water is moving in a general eastward direction, the head decreases toward the east.

\section{TYPES AND YIELDS OF WELLS}

As different beds of the Dakota sandstone differ greatly in texture and therefore in porosity, permeability, and water-yielding capacity, some beds yield large flows but others retard the water by friction and give only small flows. Moreover, some porous lenses are doubtless wholly or nearly inclosed by shale and therefore yield no flows. Wells even in the same locality may differ greatly in yield for the reason that they are not supplied by a continuous stratum.

The sandstone ranges from a very hard, compact rock to one that caves into the well. Water enters some drill holes so roily with fine sand and clay as to force the driller to abandon the hole and drill elsewhere. As many as three or four holes may thus be made on one farm, though usually the water gradually clears in a short time. Loose sand may clog the well and stop the flow. Wells whose water contains sediment must always be kept discharging, at least in a small stream, to prevent clogging. Most wells may with safety be gradually closed or nearly closed; in fact, reducing the flow will often stop the discharge of sand. 
Except in the towns nearly all wells extend only to the first artesian horizon: At the Olthoff well, in sec. 12, T. 130 N., R. 61 W., no flow was obtained at the horizon of the first water-bearing stratum, but at the depth of 1,236 feet a strong flow was obtained with 180 pounds of pressure. The power was used in 1915 to operate feed mills, and this is one of the very few places in this area where power has been developed from artesian pressure. The deeper wells at Oakes and La Moure probably reach the second horizon, and the deepest Ellendale well taps the third. The wells at the Lillebridge farm, in sec. 33, T. 132 N., R. 60 W., penetrate four water-bearing layers between depths of 900 and 1,160 feet.

In 1915 the wells near the west side of the area of artesian flow having a diameter of $11 / 4$ inches discharged from 5 to 10 gallons a minute, and those near the east side of the La Moure quadrangle 15 to 40 gallons. Along the extreme western limit of the area of artesian flow (pl. 3) nearly all wells are $1 \frac{1}{2}$ to 2 inches in diameter and many reach the second water horizon, yet they barely discharge at the surface. In 19152 -inch wells in the eastern part of the area discharged 40 to 80 gallons a minute. Most of the artesian wells in this area are $1 \frac{1}{4}$ or $11 / 2$ inches in diameter, a few are 2 inches, and wells for town supply at La Moure are 3 and $4 \frac{1}{2}$ inches, and at Ellendale $31 / 2$ and $33 / 4$ inches.

\section{IRREGULARITIES IN HEAD}

As the artesian head with reference to sea level decreases gradually toward the east, it is to be expected that in any well the water will rise slightly higher above sea level than in wells far east and not quite so high as in wells farther west. The data obtained, however, indicate irregularities in the height to which the artesian water actually rises in different wells in the same locality. Some apparent irregularities are due to inaccurate information as to the head or as to the slope and altitude of the land surface. Other irregularities are real and are found to be due chiefly to one or more of the following causes: Difference in the head of water from different layers in the Dakota sandstone, local depletion of the artesian supply, leakage of well casings, and the presence of gas in the water.

The difference in head of water from different layers has already been discussed (p. 49). In general the deepest layers had the greatest original head and have been the least depleted by wells. Thus it may happen that a well that ends at the first horizon has ceased flowing, whereas another near by that extends to a deeper horizon still flows. 
Local depletion may be due to the draft of an especially large number of flowing wells in the same vicinity or of one or more strong wells situated on especially low land, or it may be due to a tight or interrupted condition of the water-bearing beds in the particular locality, resulting in slow recharge.

Leakage of well casings is a common and well-recognized cause of loss of head in individual wells. The salts present in all the artesian water of this region cause the pipes to become corroded in time, the rate varying with the kind and amount of salt. Northwest of a line running through Merricourt, Monango, Berlin, and Grand Rapids the salts are usually of such character as to corrode the casings rapidly, and this accounts for the fact that there are relatively few flowing wells in that region. Water escaping through corroded casings or around casings that fit loosely flows underground into porous strata or comes out on the surface and forms ponds or sloughs. Some of these wells have been abandoned, but part of them continue to flow freely. All leaks lessen the pressure and cause waste of artesian water. The time required for casings to develop leaks depends somewhat on the composition of the metal used. No pipe on the market at present will, it seems, wholly withstand the corrosive action of these waters. The head of the well drilled in Ellendale in 1886 to the first water horizon was 1,715 feet above sea level, but by 1915 the pressure was reported to have fallen to 7 pounds to the square inch, which would indicate a head of only 1,466 feet, $\cdot$ a decline in 29 years of about 250 feet. The head of most wells in the vicinity of Ellendale in 1915 was, however, about 1,600 feot, and hence the great decline in the Ellendale well is probably due in part to leakage.

If a well ceases to flow because the casing has developed leaks from corrosion, the well may become clogged or the water may still be coming up from the artesian horizon to the points of escape, as could be demonstrated by lowering a current meter into the wella method used successfully by the United States Geological Survey for locating leaks in artesian wells in the Hawaiian Islands and in the Roswell artesian basin in New Mexico. ${ }^{14 a}$ If a new well is drilled near the site of such a leaky one it is likely to be a flowing well.

In many of the wells in this area considerable natural gas escapes with the water. This gas acts in the same manner as an air lift and raises the water above the level to which it would otherwise rise. Thus, of two wells at the same altitude and with the same head,

14a See U. S. Geol. Survey Water-Supply Paper 596, pp. 1-32, 1928. 
one without gas may have ceased flowing and one that yields gas may still be a flowing well.

The head and flow of wells varies slightly with the atmospheric conditions. When there is high barometric pressure some lightpressure wells cease to flow; on the other hand, low barometric pressure causes some wells to increase their flows and even to discharge sediment. These irregularities in flow are noticeable in wells along the boundary of the area of artesian flow, where the heads with reference to the surface are slight.

\section{ORIGINAL HEAD}

A report by Darton ${ }^{15}$ on artesian water in the Dakota sandstone, covering a large region that includes the Edgeley and La Moure quadrangles, gives data obtained in 1895 and 1896 and also data from earlier reports. Its data in regard to artesian head, therefore, probably represent nearly the original conditions. In this report Darton stated that the highest artesian heads found in flowing wells in the James River Valley were a little more than 1,700 feet above sea level. ${ }^{16}$ He gives the head at Ellendale as 1,727 feet, and the maximum head at Jamestown as 1,631 feet. ${ }^{17}$ As the head decreased toward the east and the high pressure at both these wells showed that the area of artesian flow must have extended farther west, it is reasonable to assume that to the west flowing wells could have been obtained at considerably higher altitudes than the heads indicated at these wells.

An artesian-water map of the Jamestown quadrangle, prepared by Darton and Willard ${ }^{18}$ in 1904 and 1905, indicates that along the line between the Jamestown and Edgeley quadrangles the west boundary of the area of artesian flow at that time was about 1,725 feet above sea level. The highest altitudes shown on the map (pl. 3) of wells in the Edgeley quadrangle that formerly flowed but that have now ceased to flow are about 1,690 feet above sea level at the Sullivan well, in sec. 23, T. 132 N., R. 65 W., and 1,680 feet at the Kern well, in sec. 33, T. 130 N., R. 65 W. These wells are respectively 1,620 and 1,727 feet deep, and the Kern well extends 47 feet below sea level.

The following original pressure heads for several old wells were generally reported in pounds of pressure to the square inch but have been recalculated in terms of head in feet above sea level.

15 Darton, N. H., Preliminary report on artesian waters of a portion of the Dakotas:

U. S. Geol. Survey Seventeenth Ann. Rept., pt. 2, pp. 609-694, 1896.

${ }^{16}$ Idem, p. 666.

${ }^{17}$ Idem, pl. 70 .

is Willard, D. E., U. S. Geol. Survey Geol. Atlas, Jamestown-'Tower folio (No. 168), 1909. 
Original pressure in certain wells in Edgeley and La Moure quadrangles

\begin{tabular}{|c|c|c|c|}
\hline \multirow{2}{*}{ Well } & \multirow[b]{2}{*}{$\begin{array}{l}\text { Date of } \\
\text { drilling }\end{array}$} & \multicolumn{2}{|c|}{ Original pressure } \\
\hline & & $\begin{array}{l}\text { Pounds } \\
\text { to the } \\
\text { square } \\
\text { inch }\end{array}$ & $\begin{array}{c}\text { Feet } \\
\text { above sea } \\
\text { level }\end{array}$ \\
\hline 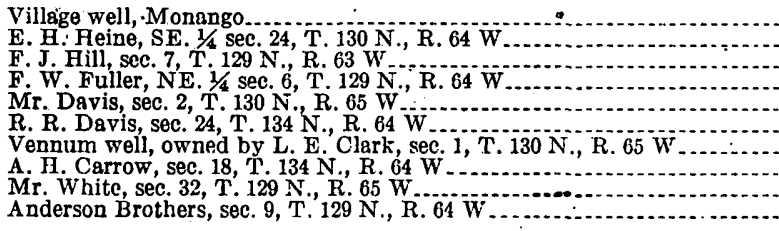 & $\begin{array}{l}1902 \\
1908 \\
1905 \\
1909\end{array}$ & $\begin{array}{r}70 \\
70 \\
90 \\
75 \\
30 \\
75 \\
75 \\
80 \\
70 \\
120\end{array}$ & $\begin{array}{l}1,660 \\
1,660 \\
1,700 \\
1,700 \\
1,700 \\
1,700 \\
1,770 \\
1,780 \\
1,790 \\
1,800\end{array}$ \\
\hline
\end{tabular}

Although it is not possible to verify all the reports as to the original pressure, the data seem to be sufficiently abundant to indicate that flowing wells could originally be obtained on land more than 1,700 feet above sea level. In the vicinity of Forbes, just south of the Edgeley quadrangle, the head was evidently greater than in most of this quadrangle, and the original area of artesian flow may there have extended above the 1,800 -foot contour.

\section{DECLINE IN HEAD AND FLOW}

The artesian wells in the Edgeley and La Moure quadrangles have undergone a gradual but notable decline in head and flow. Along the east side of the area covered in this report the flows from $1 \frac{1}{4}$-inch wells 800 to 1,000 feet deep had decreased from original discharges of 70 to 100 gallons a minute or more to only 15 to 30 gallons in 1915, and in the central part of the area they had decreased from discharges of 50 to 85 gallons a minute to less than 25 gallons, some wells having flows of only 1 to 5 gallons a minute and many having ceased flowing.

The numerous data obtained in this investigation show conclusively that the great decline in head, although complicated by the irregularities described above, is due mainly to the general depletion of the supply of artesian water in this region. (See pl. 3 and fig. 6.) When a well ceases to flow in a locality that still has many flowing wells the cause of failure is generally a corroded casing that allows the water to escape below the surface or that has caused the well to collapse and to become clogged. On the other hand, a well that is still flowing at an altitude at which most wells have ceased to flow may extend to a deeper horizon than the others or may yield more gas or may possibly owe its apparently abnormal head to some other cause not so well understood. That the decline of head is general 
and not due solely to defects in certain wells is shown from the fact that in most locations new wells do not show the original pressures of the first well but are much weaker. Illustrations of this are given above. The first well owned by R. R. Davis, drilled in 1903, had an original pressure of 75 pounds to the square inch and a flow of 29 gallons a minute. The flow dropped to 1 or 2 gallons a minute in 1915 and had ceased before 1919. Sounding in October, 1921; showed the water to be about 5 feet below the surface. The second well, drilled in 1916 a few rods from the first, had an original flow of only 7 gallons a minute. In 1919 it had a pressure of only 4 pounds and a flow of only 2 gallons. In the summer of 1920 it stopped flowing, and on October 10 the water stood 14 inches above the surface but too low to flow into the watering trough.

From year to year the head has gone progressively downward. and the west boundary of the area of artesian flow has moved steadily eastward. In the Edgeley quadrangle flows could originally be obtained on land more than 1,700 feet above sea level, by 1915 the wells above the 1,600-feet contour had nearly all ceased flowing, by 1920 . the dimit of flowing wells had descended to about the 1,550-foot contour, and by 1923 it was approaching the 1,500-foot contour. In the vicinity of Forbes, south of the Edgeley quadrangle, according to the questionnaire sent out in February, 1923, the original head was apparently nearly 1,800 feet, and in 1923 wells not far below the 1,600-foot contour were still flowing. (See fig. 6.) Thus it appears that both the original head and the head in 1923 were higher in that vicinity than in the Edgeley quadrangle, but that the total decline and the rate of decline were about as great.

At first the boundary of the area of artesian flow moved down the relatively steep slope at the base of the Coteau and thence eastward only 2 to 4 miles in 10 years. Recently it has reached the more nearly level region on the east, and its lateral movement has been more rapid. By 1923 the belt in which wells had ceased to flow was about 10 miles wide in the northern part of the Edgeley quadrangle and about 5 miles wide in the southern part.

The western boundaries of the area of artesian flow, as shown on Plate 3, refer to flow from the first and second water horizons. The boundaries for 1915 and 1923 were determined by taking into account wells that were barely flowing and those that had recently ceased flowing and by measuring the depth to the water level in nonflowing wells. West of the boundary indicated for 1923 no flow can be expected from the first and probably none from the second water horizon, but wells reaching the third horizon may flow or the water may rise in them within a practicable pumping distance. 


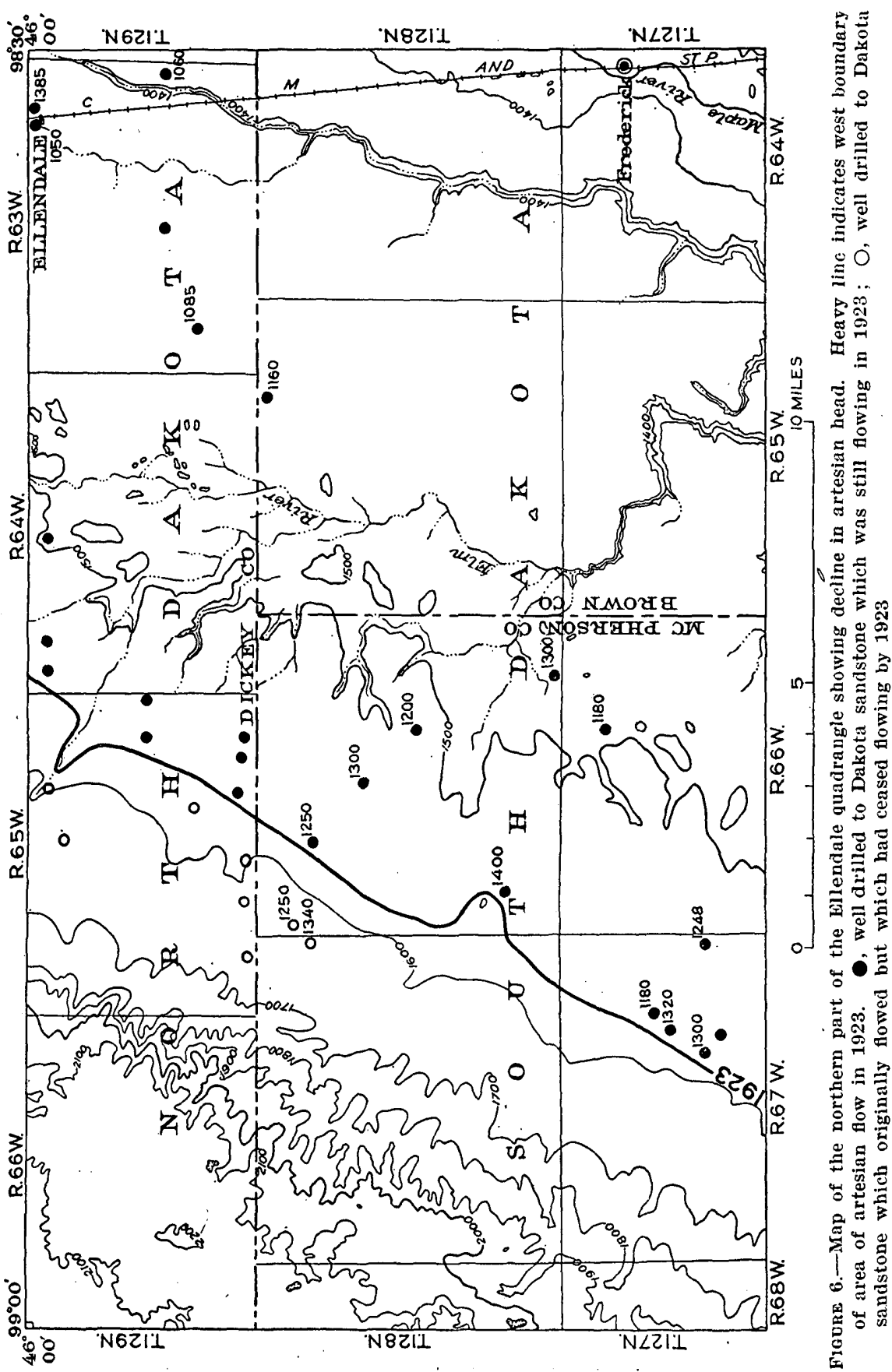


In order to bring the study in the Edgeley quadrangle up to date a questionnaire covering the present condition of the artesian wells was sent to the owners of wells in or near this quadrangle through the cooperation of the postmasters at Ellendale, Edgeley, Forbes, and Monango. Thanks are due to the postmasters for their helpful cooperation and to the well owners for their hearty response to this questionnaire. In November and December, 1923, through the cooperation of the North Dakota State Geological 'Survey, practically all the artesian wells in the quadrangle were examined by C. E. Turnbaugh under the direction of H. E. Simpson, State water geologist. The data that have been obtained in the successive surveys in regard to about 230 artesian wells in or near the Edgeley quadrangle are given in the table on pages 79-87.

\section{HISTORY OF ARTESIAN-WELI DRILIING IN THE EDGELEY QUADRANGLE}

The first well drilled to the Dakota sandstone in the Edgeley quadrangle was doubtless the well at Ellendale, which was put down in 1886. It was started with an 8-inch or 10 -inch casing but was finished at the bottom with $33 / 4$-inch casing, the lower 40 feet of which was perforated with $3 / 4$-inch holes. The next well drilled to the Dakota sandstone in the quadrangle of which there is any record is the city well at Edgeley, which is reported to have been 6 inches in diameter and to have been put down in 1892. C. E. Turnbaugh, who made the survey in 1923 for the present report, has been a driller in the Edgeley quadrangle since 1902. In so far as he has information these two wells were the only wells drilled to the Dakota sandstone prior to 1902. In 1902 he drilled a 21/2-inch well for the village of Monango. About this time wells with small diameter came into use throughout the artesian basin, and owing to their low cost numerous $11 / 4$ and $11 / 2$ inch wells were put down for farm supplies. Most of the artesian wells in the Edgeley quadrangle were drilled between 1904 and 1912; drilling was most active between 1905 and 1910, and very few artesian wells have been drilled since 1915 .

Prior to 1915 the decline in water level in the Hassenger, Chambers, and Webb wells was more than 5 feet in a year, in the Halstead well about 8 feet, and in the Kern well about 10 feet. In some wells in this region the head dropped 80 to 130 feet or more in a period of 8 to 10 years prior to 1915 .

The cause of this great and widespread loss of head and flow is not difficult to find. Hundreds of wells have been allowed to run full force for no adequate reason, and as a result the artesian sup- 
ply has been greatly diminished. The wells in the higher parts of the basin have ceased to flow, and wells at still lower level will eventually cease to flow if effective regulations are not adopted to conserve the artesian water.

\section{ORIGINAL HEAD AND AREA OF ARTESIAN FLOW}

The original artesian head in different parts of the area can never be ascertained with great precision. The artesian-water map of South Dakota by Darton, ${ }^{19}$ which was published in 1909 but which doubtless shows the approximate conditions at a considerably earlier time, indicates that in the southern part of the Edgeley quadrangle the area of artesian flow extended westward nearly to the 1,800-foot contour. It also indicates that in this part of the artesian basin the hydraulic gradient, or eastward decrease in artesian head, was about 4 feet to the mile. This agrees approximately with an original hydraulic gradient of $41 / 3$ feet to the mile from Highmore to Huron, S. Dak., as given by Powell ${ }^{20}$ in 1890. According to Powell's report, ${ }^{21}$ made in 1890 , the pressure of the water in the well at Ellendale drilled in 1886 was 175 pounds to the square inch. According to Mr. J. R. Lacey, a resident of Ellendale, who was present when this well was drilled and who is probably the best-informed man on the entire history of artesian wells at Ellendale, the pressure in this well was measured on the day the well was completed and was found to be 145 pounds. In the report by Nettleton, ${ }^{22}$ published in 1892, a pressure of 115 pounds is given for this well, apparently based on measurements made by Nettleton in 1890. It seems reasonable to believe that the records of very high original pressure in the earliest wells drilled to the Dakota sandstone are approximately correct. Such pressures were doubtless maintained only a short time and hence were not corroborated by reliable measurements a few years later. It is evident also that those who made and reported the reliable measurements a few years later were not alert for data as to decline, but rather assumed that the high pressures and flows were permanent. A pressure of 145 pounds at Ellendale would give a head of about 1,785 feet with reference to sea level-that is, it would be sufficient to raise the water in a casing or standpipe to an altitude of 1,785 feet above sea level. If the original head at Ellendale was 1,785 feet and the original hydraulic gradient 4 feet to the mile, the original west boundary of the area of artesian flow was

\footnotetext{
10 Darton, N. H., Geology and underground waters of South Dakota : U. S. Geol. Survey Water-Supply Paper 227, pl. 11, 1909.

${ }_{20}$ Powell. J. W., Artesian irrigation on the Great Plains : U. S. Geol. Survey Eleventh Ann. Rept., pt. 2, p. 273, 1891.

2 Idem, p. 269.

2 Nettleton, E. S., Artesian and underflow investigation : 52d Cong., 1st sess., S. Ex. Doc. 41, pt. 2, pp. 67, 68, table opposite p. 74, 1892.
} 
about 16 miles west of Ellendale, at an altitude of about 1,850 feet above sea level.

An artesian-water map, by Darton and Willard, ${ }^{23}$ of the Jamestown quadrangle, which lies immeldiately north of the Edgeley quadrangle, was published in 1909 but is based on studies made in earlier years. It shows the west margin of the area of artesian flow at the boundary between the Jamestown and Edgeley quadrangles to have been at about 1,725 feet above sea level. According to the available record, the city well at Edgeley, drilled in 1892, had an original pressure of 60 pounds to the square inch, or a head of about 1,690 feet with reference to sea level. Therefore if in 1892 the gradient was 4 feet to the mile, the west margin of the area of artesian flow lay about 6 miles west of Edgeley, or about 1,715 feet above sea level. The original pressure in the vicinity of Edgeley was probably somewhat greater than the pressure recorded in 1892 .

In view of these data it seems reasonable to assume that the original west boundary of the area of artesian flow in the Edgeley quadrangle ranged from somewhat less than 1,800 feet above sea level in the northern part to somewhat more than 1,800 feet in the southern part and had an average altitude of fully 1,800 feet.

\section{DECLINE IN HEAD FROM 1886 TO 1923}

The well at Monango, drilled in 1902, is reported to have had an original pressure of 70 pounds to the square inch, or a head of about 1,660 feet with reference to sea level-about 125 feet less than the Ellendale well in 1886, about 55 feet less than the Ellendale well in 1890, and about 30 feet less than the Edgeley well in 1892. Other data (given in the table on pp. 79-87) indicate a considerable drop in head prior to 1902 .

During the period from 1902 to 1915, which was the period of active well drilling, the artesian head dropped rapidly. According to computations on 20 wells for which more or less satisfactory data are available, the average annual decline during this period was 12.7 feet, which for the whole period would amount to 165 feet.

During the period from 1915 to 1920 the decline, according to similar computations on 12 wells, averaged about 4 feet a year, or about 20 feet for the period. During the period from 1920 to 1923 the decline, according to computations on 20 wells, averaged about 4 feet a year, or about 12 feet for the period.

The foregoing computations are based on available wells within the original area of artesian flow in the Edgeley quadrangle and in a belt several miles wide adjacent to this quadrangle on the south. They indicate a decline of about 200 feet from 1902 to 1923 and a

${ }_{23}$ Willard, D. E., U. S. Geol. Survey Geol. Atlas, Jamestown-Tower follo (No. 168), 1909.

$6147-29-5$ 
considerably greater decline from 1886 to 1923 . Computations that take into account the geographic distribution of the wells (see p. 61 and fig. 7) indicate, however, that the average decline for the entire area has not been quite so great. On the assumption that the original pressure in the Ellendale well was 145 pounds to the square inch, they indicated that the decline in the southeast corner of the quad-

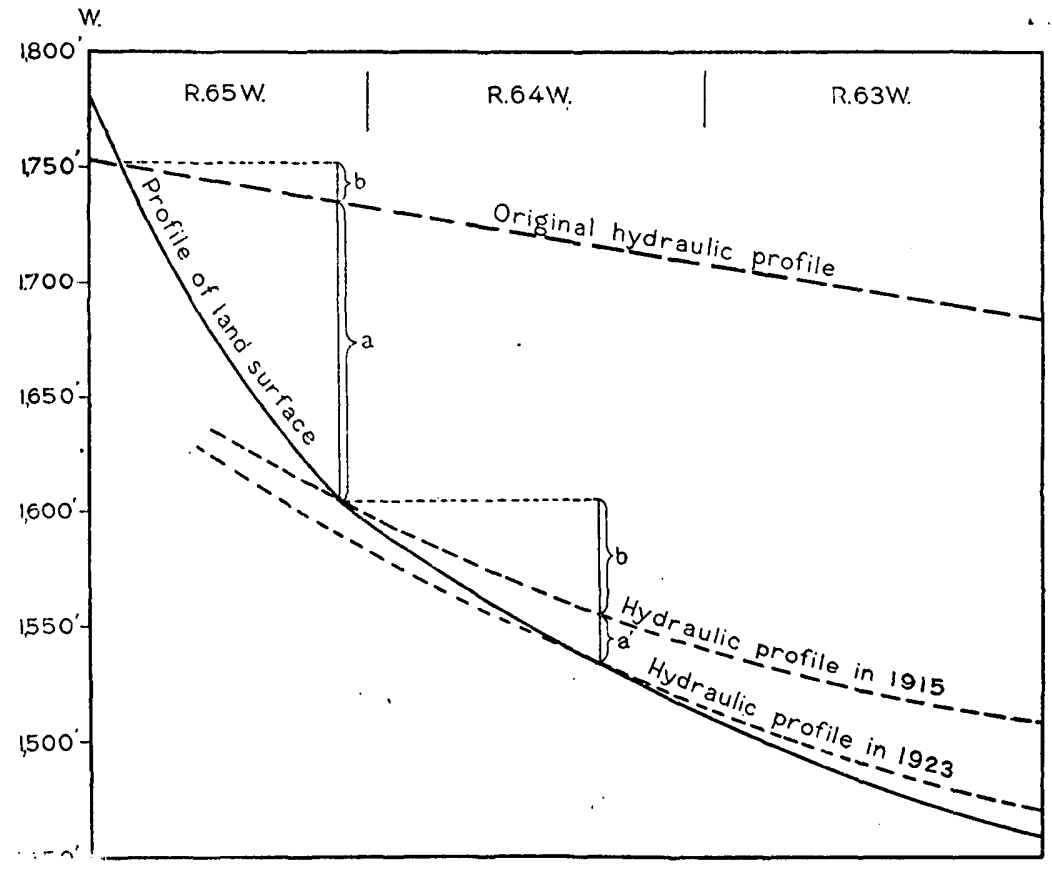

Figure 7.-Generalized east-west section of the area of artesian flow in the Ddgeley quadrangle, showing approximately the profle of the land surface, the original hydraulic profle, and the hydraulic proflles in 1915 and 1923. The hydraulic profle for any particular year indicates how high the water from the upper part of the Dakota sandstone would rise at each point along the section in that year. $a$, Decline in head prior to 1915 in wells at position of artesian boundary in $1915 ; b$, original difference in head between wells at original boundary and wells at boundary in $1915 ; a^{\prime}$, decline in head from 1915 to 1923 in wells at position of artesian boundary in $1923 ; b^{\prime}$, difference in head in 1915 between wells at boundary in 1915 and wells at boundary in 1923 . $a+b$, Descent of artesian boundary prior to $1915 ; a^{\prime}+b^{\prime}$, descent of artesian boundary from 1915 to $1923 ;(a+b)+\left(a^{\prime}+b^{\prime}\right)$, total descent of artesian boundary prior to 1923

rangle amounted to over 300 feet, but that the average for the entire area was more nearly 250 feet. If the original pressure at Ellendale was 175 pounds to the square inch the total decline was about 70 feet greater.

\section{SHRINKAGE IN THE AREA OF ARTESIAN FLOW}

According to the lower assumption as to the original head, the area of artesian flow originally extended westward to an altitude of somewhat less than 1,800 feet near the north:margin of the Edgeley 
quadrangle and to an altitude of somewhat more than 1,800 feet near the south margin. In 1902 it apparently still extended to an altitude of 1,700 feet or more, except possibly near the north margin of the quadrangle. By 1915 the west boundary of the area of artesian flow had come down the slope about 200 feet, so that it lay somewhat below the 1,600-foot contour in the northern part of the quadrangle and somewhat above the 1,600-foot contour in the southern part. (See pl. 3 and fig. 7.) By 1923 this artesian boundary had migrated eastward to the flat land, where the slope of the surface nearly coincided with the hydraulic gradient, and over a wide belt the artesian water rose to about the surface-slightly above the surface in some wells and slightly below in others. Therefore, in 1923 the boundary of the area of artesian flow was a less definite line than it had been originally or in 1915. It is, however, approximately correct to say that from 1915 to 1923 the boundary descended about 75 feet, and that in 1923 it was about 1,500 feet above sea level at the north margin of the quadrangle and about 1,550 feet at the south margin. (See pl. 3 and fig. 7.) A considerable part of this descent occurred between 1920 and 1923. According to the lower assumption as to the original head, the total descent of the west boundary of the area of artesian flow from the time the first wells were drilled until 1923 was about 275 feet. The belt in which flowing wells were originally obtained but in which the wells have ceased to flow is about 10 miles wide in the northern part of the quadrangle and 5 miles wide in the southern part. (See pl. 3.) Fully half of this belt has "gone dry" in the 8-year period since 1915, during which only a few wells were drilled.

\section{INOREASE IN HYDRAULIC GRADIENT}

A geographic analysis of the data indicates that the decline in artesian head has been greater along the east margin of the Edgeley quadrangle than farther west and hence that the hydraulic gradient has increased. According to the best information available, the original gradient was only about 4 feet to the mile, whereas the gradient in 1923 was about 10 feet to the mile in the eastern part of the quadrangle and fully 15 feet to the mile west of the 1,600-foot contour (fig. 7). These figures may be considerably in error, the original gradient especially being in doubt, but the available records of decline from year to year in artesian head and in depths to the water level in wells that have ceased to flow give evidence of relatively small decline in head in the western part of the original area of artesian flow. They seem to lead to the significant conclusion that the effect of the great decline in head becomes slight or dies out entirely long before the western outcrops of the sandstone are reached. 
CORRELATION OF DECLINE IN HEAD WITH DESCENT OF ARTESIAN BOUNDARY

According to the computations, the results of which have been given, the descent of the artesian boundary was less than the average decline in head during the period prior to 1915 but much greater than the average decline during the period from 1915 to 1923 . To the casual reader these differences may appear to be discrepancies in the results. On account of the fragmentary and uncertain data in regard to conditions in the early years of artesian development, no claim of accuracy can be made for these computations, but it should be noted that the results are about as would be expected when the topography and the changes in hydraulic gradient are taken into consideration.

In Figure 7 the vertical distance $a$ represents the decline in head prior to 1915 at the point shown, and the vertical distance $a+b$ represents the descent of the artesian boundary prior to 1915. Because of the steep slope of the land surface the large decline in head did not produce any great lateral movement of the artesian boundary. For this reason and because of the slight original hydraulic gradient the descent of the artesian boundary $(a+b)$ was only slightly greater than the decline in head $(a)$ at the point shown. But farther east the decline in head was greater than at this point, as is indicated in Figure 7 by the increased vertical distance to the east between the original hydraulic profile and the hydraulic profile in 1915. Hence the vertical distance through which the artesian boundary descended during this early period was somewhat less than the average decline in head.

The vertical distance $a^{\prime}$ represents the decline in head from 1915 to 1923 at the point shown, and the vertical distance $a^{\prime}+b^{\prime}$ represents the descent of the artesian boundary during this period. Because of the more gentle slope of the land surface in the belt through which the artesian boundary had to pass in this later period the relatively small decline in head $\left(\sigma^{\prime}\right)$ produced fully as great a lateral movement of the artesian boundary as had been produced by the great decline $(a)$ in the period prior to 1915. For this reason and because of the greater hydraulic gradient the descent of the artesian boundary $\left(a^{\prime}+b^{\prime}\right)$ was much greater than the decline in head at the point shown $\left(a^{\prime}\right)$ and also much greater than the average decline in head.

\section{YIELD OF FLOWING WELLS AND DECLINE IN YIELD}

The flow of the $33 / 4$-inch well at Ellendale drilled in 1886 was 600 gallons a minute according to Powell's report, ${ }^{24}$ published in 1891, and 700 gallons a minute in 1890 according to the Nettleton report, ${ }^{25}$

24 Powell, J. W., op. cit., p. 269.

\& Nettleton, E. S., op. cit.; table opposite p. 74. 
published in 1892. The original flow of the 6-inch well at Edgeley drilled in 1892 is reported to have been 500 gallons a minute. ${ }^{26}$ The $2 \frac{1}{2}$-inch well drilled at Monango in 1902 is reported by C. E. Turnbaugh, the driller, to have had an original flow of only 45 gallons a minute.

According to an estimate by Hard, the original discharge of $11 / 4^{-}$ inch wells drilled prior to 1915 in the Edgeley and La Moure quadrangles was about 50 to 100 gallons a minute. According to the estimates of Turnbaugh and other drillers and well owners, as given in the table on pages 79-87, the original discharge of 166 wells drilled in the Edgeley quadrangle from 1902 to 1914, inclusive (not including the deep well drilled at Ellendale in 1908 to a deeper horizon), was only $221 / 3$ gallons a minute. These 116 wells were nearly all $11 / 4$ or $11 / 2$ inches in diameter.

Hard also estimated for the Edgeley and La Moure quadrangles that in 1915 the flow from 11/4-inch wells was 5 to 10 gallons a minute near the west side of the area of artesian flow and 15 to 40 gallons farther east. However, the average discharge of 20 wells measured in 1915 by H. M. Derr, ${ }^{27}$ State engineer of South Dakota, in Brown County, which lies south of these quadrangles, was only about 11 gallons a minute.

The flow of 41 wells measured by Hard in the Edgeley quadrangle in 1919 and 1920 ranged from a fraction of a gallon to 20 gallons a minute and averaged $7 \% / 3$ gallons.

In 1923 the flow of 111 artesian wells was measured by Turnbaugh-all in the Edgeley quadrangle except a few that were just outside. This list included nearly but not quite all the flowing wells in the quadrangle. The 111 wells were found to have an aggregate flow of 343 gallons a minute, or an average flow of 3.09 gallons a minute. With few exceptions the flows were measured after the wells had been opened as much as possible, and the results therefore represent more than the actual discharge of the wells in their normal condition.

\section{SPECIFIC OAPACITIES OF FLOWING WELLS}

The specific capacity of a flowing well is its flow per foot of head. If there is no change in the intake facilities of a well, its specific capacity will remain nearly the same whether the head is high or low. Thus if the specific capacities of the wells that tap the Dakota sandstone can be determined they will give a check on the reported flows of the wells in the earlier years when the heads were high and

${ }^{20}$ Darton, N. H., U. S. Geol. Survey Seventeenth Ann. Rept., pt. 2, p. 661, 1896.

27 Derr, H. M., Report on artesian wells: South Dakota State Engineer Sixth Bienn. Rept., for 1915-16, pp. 177-187, 244-248. 
will also give a clue as to the permeability of the sandstone and hence as to the rate of recharge.

For 23 wells in the Edgeley quadrangle there is fairly reliable information as to head and flow, which was used in calculating the specific capacities of these wells. For four of these wells check calculations could be made, because this information was available for different years and hence for different heads. In one of these four wells the specific capacity was 0.40 gallon a minute for each foot of head in 1906 and 0.25 in 1920; in another it was 0.15 in 1909 and 0.24 in 1915; in a third it was 0.28 in 1902 and 0.29 in 1920; and in the fourth it was 0.09 in 1920 and 0.09 in 1923 . Thus the calculations for different years and very different heads agreed as closely as could be expected.

The data in regard to the specific capacities of the 23 wells for which calculations could be made are summarized in the following table:

Specific capacities of wells in the Edgeley quadrangle

\begin{tabular}{|c|c|c|c|c|}
\hline \multirow{2}{*}{$\begin{array}{c}\text { Diameter } \\
\text { (inches) }\end{array}$} & $\begin{array}{c}\text { Number } \\
\text { of wells }\end{array}$ & \multicolumn{2}{|c|}{$\begin{array}{c}\text { Specific capacity (gallons a minute } \\
\text { for each foot of head) }\end{array}$} \\
\cline { 2 - 4 } & & Maximum & Minimum & Average \\
\hline 6 & 1 & 3.62 & 3.62 & 3.62 \\
$33 / 4$ & 1 & 2.64 & 2.64 & 2.64 \\
$21 / 2$ & 1 & .29 & .29 & .29 \\
21 & 4 & 1.40 & .57 & .80 \\
$11 / 2$ & 3 & .57 & .20 & .35 \\
$11 / 4$ & 12 & .36 & .09 & .22 \\
1 & 1 & .14 & .14 & .14 \\
1 to 2 & 20 & 1.40 & .09 & .25 \\
(inclusive). & & & & \\
\hline
\end{tabular}

If the average flow of the small wells is one-fourth gallon a minute for each foot of head, then the average flow should have been 50 gallons a minute when the head was 200 feet, 25 gallons when it was 100 feet, 10 gallons when it was 40 feet, 3 gallons when it was 12 feet, and so on.

\section{TOTAL DISOFARGE OF FLOWING WELIS}

As the water in the Dakota sandstone comes from the west and moves in general toward the east, a study of discharge, recharge, and depletion of the artesian-water supply should obviously relate to an east-west belt extending across the entire area of artesian flow unless a complete survey of the entire basin can be made. Hence for this purpose calculations have been made for the tract covered by T. 129 N., Rs. 48-65 W., and not for the Edgeley quadrangle.

It was estimated by Darton ${ }^{28}$ that in 1896 the total discharge from flowing wells which ended in the Dakota sandstone in the

\footnotetext{
${ }^{28}$ Darton, N. H., U. S. Geol. Survey Serenteenth Ann. Rept., pt. 2, p. 609, p1. 69, 1896.
} 
area that he covered was 104,000 gallons a minute. This area included most of the area of artesian flow of the Dakota sandstone in North and South Dakota and had a north-south extent of nearly 300 miles. His estimate therefore gives an average discharge of a little more than 2,000 gallons 'a minute for an east-west row of townships in the area. As most of the strong wells were in South Dakota, the average for the part of the area that lies in North Dakota must have been much less than 2,000 gallons a minute. The only well in the T. 129 row shown by Darton's report was the Ellendale well, with a flow of 700 gallons a minute.

In 1923, in connection with the enforcement of the artesian-water law, practically all flowing wells in this row of townships were inspected by Howard E. Simpson, water geologist of the North Dakota Geological Survey, and his deputy, C. E. Turnbaugh. The data obtained in this inspection were generously furnished by Professor Simpson for use in this report. They show that in T. 129 N., Rs. 50 to $65 \mathrm{~W}$., inclusive, there were 320 flowing wells supplied by the Dakota sandstone, which were normally discharging an aggregate of 965 gallons a minute, or an average per well of 3.02 gallons a minute. In addition were the wells that supplied the waterworks in six towns and five farm wells that were closed except when the faucets were turned on. It was estimated that an average of about 40 gallons a minute was drawn from these wells, making an aggregate flow of 1,005 gallons a minute. It was estimated by Simpson and Turnbaugh that the aggregate flow in this row of townships in 1923 was about one-half the aggregate flow in 1920that is, that the flow from all wells in this row of townships in 1920 was about 2,000 gallons a minute, or about 6 gallons a minute per well. No flowing wells were reported in T. 129 N., Rs. 48 and 49 W.

On the basis of all available data and with the assumption that the history of well drilling in the T. 129 row was similar to that given for the Edgeley quadrangle, a rather elaborate calculation was made of the quantity of water that has been discharged from the Dakota sandstone through wells in this row of townships. This calculation gave an average discharge during the 38-year period from 1886 to 1923 of somewhat less than 3,000 gallons a minute. The peak discharge doubtless occurred at some time between 1905 and 1910 and probably did not exceed 10,000 gallons a minute. It is recognized that these estimates may be very inaccurate, but they are probably as good as can ever be made and are believed to be worth presenting in order to give some tangible conception of the quantities of water that are involved and the stage of depletion that has been reached. It is believed that the total quantity of artesian water discharged at the surface in an average row of townships in 
this artesian basin in North Dakota did not exceed the quantity represented by these figures-that is, 3,000 gallons a minute for a period of 38 years. No estimate can be made of the underground waste through leaky casings. However, it is generally believed by those best qualified to judge that the aggregate underground waste is not very large because of the great thickness of plastic clay that tends to seal the old wells when the casing becomes corroded.

\section{BENEFICIAL FLOW AS ESTIMATED BY THE STATE GEOLOGICAL SURVEY}

On the basis of the information obtained in the inspection a careful estimate was made by Professor Simpson of the extent to which each of the 320 wells can be reduced in order to stop all unnecessary discharge without depriving the farmer of any beneficial use or working any hardship. The term " unnecessary discharge" is used to designate the discharge that serves no useful purpose: Reasonable allowances were made for a flow of water that will run to waste but will be necessary to prevent freezing of the pipes or clogging of the well. The results of this work showed that by stopping the unnecessary discharge the flow can be reduced to 377 gallons a minute from the 320 wells, or to an average of 1.18 gallons a minute per well. This makes the aggregate beneficial flow amount to 417 gallons a minute from existing wells in this row of townships, including the necessary flow from the waterworks wells and the closed farm wells.

\section{RATE OF RECHARGE}

An effort was made to estimate for the T. 129 row of townships the rate at which the water in the Dakota sandstone is percolating eastward in the direction of the hydraulic gradient. It was assumed that, whereas the townships both to the north 'and to the south have similar artesian-water developments, this row of townships is supplied by the artesian water directly west of it and neither draws from nor contributes to the adjacent townships. Such an estimate would be of great practical value, because it would serve as a basis for judging how much further the discharge must be reduced, either by natural lowering of the head or by voluntary or enforced conservation, before a balance is struck between discharge and recharge. Unfortunately the information in regard to both thickness and texture of the water-bearing sandstone strata 'is so meager and unsatisfactory that it is impossible to make any estimate in which much confidence can be placed. Calculations based on Slichter's formula ${ }^{29}$ show, however, that if the hydraulic gradient is 10 feet

29 Slichter, C. S., Field measurements of the rate of movement of underground water: U. S. Geol. Survey Water-Supply Paper 140, pl. 2, 1905. 
to the mile and the sandstone strata which supply the wells under consideration have a thickness of 60 feet, a porosity of 35 per cent, and an effective size of grain of 0.17 millimeter-the same as that of the St. Peter sandstone as determined in numerous tests ${ }^{30}$ - the rate of recharge or eastward percolation is about equal to the 417 gallons a minute estimated by Simpson as the quantity needed for present beneficial use without any unnecessary discharge and without allowing anything for possible underground leakage. There are no good reasons for believing that the rate of recharge is greater than this amount.

The problem of recharge was then approached by another line of reasoning, as follows: During the period from 1915 to 1923, with progressive decrease in the rate of discharge, there was progressive decline in pressure head, indicating that depletion was going on. In 1923, with a discharge of only 1,000 gallons a minute, the head was apparently still declining, which would seem to indicate that the recharge was less than 1,000 gallons a minute. It can not be argued that the rate of recharge decreased on account of decrease in the hydraulic gradient, because the evidence seems to show that at the entrance to the area of artesian flow the hydraulic gradient actually increased from 1915 to 1923 . For example, the pressure head dropped farther during this period at Ellendale, N. Dak., than at the margin of the area of artesian flow 10 to 13 miles farther west. (See fig. 7.)

It is at least interesting to recall that in 1890 , when the artesian wells still had tremendous pressure and flow, Major Powell, at that time Director of the United States Geological Survey, estimated in a hearing before a congressional committee, on an entirely different basis, that the total recharge amounted to about 475 gallons a minute for each row of townships and the recoverable recharge to one-half that amount. ${ }^{31}$

\section{WITHDRAWAL OF STORED WATER AND COMPRESSION OF THE DAROTA SANDSTONE}

The foregoing considerations raise the question as to the source of the artesian water that has been discharged during the last 38 years and that is being discharged at present. If the rate of discharge in the area of artesian flow has been more rapid than the rate at which water percolated into the sandstone underlying this area, some of the water discharged must have been derived from storage in the sandstone underlying the area. This requires a reduction in the inter-

${ }^{30}$ Dake, C. L., The problem of the St. Peter sandstone : Missouri Univ. School of Mines and Metallurgy Bull., August, 1921, pp. 152-177. See also Meinzer, O. E., U. S. Geol. Survey Water-Supply Paper 489, pp. 119, 120, 1924.

a Powell, J. W., op. cit., p. 274. 
stitial space occupied by water. Either the water was replaced in some of the interstices by gas, or else the sandstone has a volume elasticity, so that, as the buoying force of artesian pressure within the sandstone was relieved, the sandstone underwent a certain amount of compression in which its total interstitial space was reduced by a volume equal to the volume of the stored water that was discharged. The theory of gas accumulation is believed to be untenable. Hard states that the gas discharged by some of the wells seems to occur as an unsaturated solution in the artesian waters of the Dakota sandstone and apparently is released from solution by the reduction of pressure incident to the rise of the water to the surface (p. 76). There is no indication that gas occurs in the sandstone in the gaseous state at the present time.

If the theory of gas accumulation is dismissed the theory of volume elasticity and resulting compression of the sandstone is supported by two other lines of evidence-the apparently rapid dying out toward the west of the decline in artesian head, and the long period required for a flowing well to recover its full pressure after it has been closed and a pressure gage has been attached.

If a perfectly tight and inelastic tank were filled with water under great pressure and were then tapped, only a minute quantity of water, equal to the expansion of the water itself, would have to be discharged in order to relieve all the pressure. On the other hand, if the tank were made of elastic material, such as rubber, the discharge would continue, at a constantly diminishing rate, until the strain of the walls of the tank would be almost completely relieved. For this reason pressure tanks used in waterworks are always kept partly filled with air, which furnishes the necessary elasticity. If the Dakota sandstone were perfectly incompressible, any considerable withdrawal of water ought to have resulted in a rapid drop in head and a prompt readjustment of the hydraulic gradient all the way from the area of artesian flow to the outcrop from which the water is derived, hundreds of miles away. This readjustment ought to have occurred with only slight movement of the artesian water. After the readjustment had been made conditions ought to have remained nearly constant, or if the water level at the outcrop had declined there ought to have been a gradual flattening of the hydraulic gradient.

The changes that actually took place seem to have been of very different character. The head did not drop off suddenly but has been declining gradually for about 40 years. The survey made in 1923 showed that there has been only comparatively small decline in the water levels in the wells near the western margin of the area of artesian flow, suggesting that in all these years there has not been much 
readjustment of the hydraulic gradient beyond the area in which artesian water was withdrawn. Moreover, near the west end of the area of artesian flow for which data are available the hydraulic gradient has not flattened out but instead has become steeper. (See fig. 7.)

In order to reach conclusive results more data are needed as to the head in the large region between the area of flow and the outcrop, but the data at hand certainly point to the conclusion that the Dakota sandstone has not behaved like an inelastic reservoir and that the water discharged by the flowing wells has largely been derived locally from storage and not by transfer of water all the way from the outcrop.

In testing the pressure in flowing wells in the Dakota artesian basin, Mr. Hard found that after a well was closed and the gage was attached the pressure would run up quickly at first and would then continue to increase for some time at a constantly diminishing rate. These observations confirmed the reports of earlier investigators. Nettleton, ${ }^{32}$ in his investigations in 1890 and 1891, found that the wells differed greatly in regard to the time required for them to recover their full head. In some the recovery was very prompt, but in others it was notably slow. In regard to the well at Frederick, S. Dak., Nettleton stated that "the pressure increases for several hours or even days after the flow is shut off, and when opened the flow decreases in the same way until the normal flow is reached, which corresponds somewhat to the time required to gain its maximum pressure." In regard to several other wells with slow recovery he made the following comments:

Plankington, S. Dak.: "When the flow is shut off the pressure quickly runs up to 50 pounds and in three hours it reaches its maximum, 91 pounds per square inch." Wolsey, s. Dak.: "If the well has been discharging freely for some time it takes about 18 hours for it to reach its maximum pressure after the water is shut off." Woonsocket, S. Dak.: "The pressure is 125 pounds per square inch when the flow is shut off. * The well was allowed to flow freely for 48 hours and was then closed, when it showed a pressure of 85 pounds. " A few hours afterward the closed pressure was 93 pounds." Ellendale, N. Dak. : "When the flow is shut off the pressure rises quickly to 80 nounds and in a few hours it reaches its maximum, which is 115 pounds."

The explanation of the slow recovery seems to be that the waterbearing bed has a certain amount of volume elasticity, that it becomes compressed when the artesian pressure is relieved, and that before the pressure in the well can again reach the pressure that is general in the formation sufficient time has to elapse to allow the water to percolate into the depleted and compressed part of the formation immediately surrounding the well and to expand

sa Nettleton, E. S., Artesian and underflow investigation : 52d Cong., 1st sess., S. Ex. Doc. 41 , pt. 2 , pp. $40-74,1892$. 
the interstitial space. So long as the pressure in the shut-down well has not reached the maximum there is obviously a hydraulic gradient from all directions toward the well. But wherever there is. a hydraulic gradient in the water in a permeable rock there is movement of the water in the direction of the gradient. Throughout the period of recovery water is therefore percolating toward the well. But if the well is tightly cased this water has no means of escape. It must be stored in the interstices of the formation in the vicinity of the well. If there are no unfilled interstices at the beginning of the period of recovery, as the conditions seem to require, the conclusion must be reached that the inflowing water is stored in space made available by the expansion of the sandstone. If the sandstone were perfectly inelastic the recovery would be nearly instantaneous and would occur without the transfer of any appreciable quantity of water toward the well.

If the foregoing calculations were accurate, they would afford a basis for computing the amount of compression which, according to this theory, was involved. If in the last 38 years the average rate of discharge was 3,000 gallons a minute and the average rate of recharge only 500 gallons a minute, the average withdrawal from storage amounted to 2,500 gallons a minute. If the area of depletion consists of the 18 townships described as T. 129 N., Rs. 48-65 W., a total discharge of 3,000 gallons a minute for 38 years would amount to a layer of water 5.3 inches deep over all of this area, and a withdrawal from storage of 2,500 gallons a minute would amount to a layer of water 4.4 inches deep.

The first well at Ellendale, according to Figure 3 (p. 14), reached the Dakota sandstone at a depth of 1,035 feet and penetrated the Dakota 52 feet. The beds above the Dakota are chiefly soft shale, which, with the water they contain, must have a specific gravity of about 2. Hence these beds, owing to their weight, exert a pressure equal to that of a column of water about 2,070 feet high, or 898 pounds to the square inch. If the original head of the artesian water in this well was 333 feet at the surface (145 pounds to the square inch), then the artesian pressure at the top of the Dakota sandstone was that of a column of water 1,368 feet high, or 594 pounds to the square inch. Therefore, 594 pounds to the square inch of the pressure exerted by the beds that overlie the Dakota sandstone was supported by the water in the sandstone, and only 304 pounds by the sandstone itself. If at any point within the area of artesian flow the head at the surface was as great as the depth to the Dakota sandstone, the artesian pressure must have been great enough virtually to float the overlying beds. As the head at Ellendale has declined approximately 333 feet ( 145 pounds to the square inch) the burden placed on the sandstone has increased from about 304 pounds to 449 
pounds, or $471 / 2$ per cent. If the original pressure in the Ellendale well was 175 pounds, the burden has increased $611 / 3$ per cent. It has long been known that at least slight compression of water-bearing beds may result from additional loads at the surface, such as tides or even railroad trains. ${ }^{38}$ It is also well known that, other things being equal, the porosity of rocks decreases with depth because of increase in the weight they must support. ${ }^{34}$ It seems within the range of possibility, therefore, that the upper part of the Dakota sandstone, which is here being considered, should have undergone a compression of a few inches-probably less than 1 per cent-as a result of the release of the expansive force of artesian pressure and a consequent increase of about one-half in the load upon the formation.

In order to obtain a more adequate basis for conclusions as to the behavior of the artesian water precise data are greatly needed (1) as to the mechanical composition, porosity, and permeability of the sandstone in each stratum of the Dakota sandstone and (2) as to the fluctuation of the artesian head in flowing wells and of the water level in nonflowing wells that end in the Dakota sandstonein the areas of artesian flow, at the outcrops, and so far as possible at intermediate points. These observations on artesian head and water levels are needed not only to determine the hydraulic profile and its progressive modification but also to ascertain to what extent seasonal fluctuations in the water table at the outcrops are transmitted to the remote parts of the formation.

\section{BENEFIOIAL EFFECT OF THE CONSERVATION POIIOY ADOPTED BY THE STATE OF NORTE DAKOTA}

All the theoretical considerations above set forth have an intensely practical bearing on the policy of conservation of the artesian water that has been adopted by the State of North Dakota. The great and progressive decline in artesian head is well established, and the desirability of preventing further decline and of saving the wells that are still flowing is generally recognized. The only question that remains is whether the decline can be stopped by the measures that are being put into effect. Although satisfactory data as to the rate of recharge are lacking, enough information has been obtained on the subject to indicate that the conservation already effected and the further conservation outlined by Howard E. Simpson, the water geologist of the State Geological Survey, will tend to keep the wells flowing.

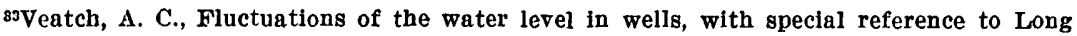
Island: U. S. Geol. Survey Water-Supply Paper 155, pp. 65, 75, 1906.

${ }^{34}$ Sorby, H. C., On the application of quantitative methods to the study of the structure and history of rocks: Geol. Soc. London Quart. Jour., vol. 64, p. 214, 1908 . Meinzer, O. E., U. S. Geol. Survey Water-Supply Paper 489, p. 8, 1924. The theory of compression is discussed in a more recent paper (Meinzer, O. E., Compressibility and elasticlty of artesian aquifers : Econ. Geology, vol. 23, pp. 263-291, 1928).
} 
Decline in artesian head will cease when a balance is reached between the discharge from the artesian wells and the natural recharge. Apparently this balance has not yet been reached. Between 1920 and 1923 there was considerable decline, and a number of wells ceased flowing. The annual recharge for each row of townships across the area of artesian flow east of the Coteau du Missouri is probably less than the 1,000 gallons a minute that was being withdrawn in the T. 129 row in 1923. The decrease in flow from 2,000 to 1,000 gallons a minute from 1920 to 1923 has been due only in part to natural decline. In large part it is due, according to the observations of Simpson and Turnbaugh, to the reduction of discharge openings in the artesian wells which have been made by the well owners since the artesian-water law went into effect, March 10, 1921. The reductions were made in part as a result of education and the influence of the drillers through the North Dakota Well Drillers Association. It was also estimated by Simpson that in T. 129 N., Rs. 63, 64, and 65 W., largely owing to the detailed work done in these townships by Hard, the reduction from 1920 to 1923 amounted to fully two-thirds. It is probably no exaggeration to say that the saving that has been accomplished in this row of townships through the reduction of the discharge openings of wells since the law was enacted is as great as the waste that was still going on in 1923-in other words, that onehalf of the possible conservation had already been accomplished in 1923, largely through the intelligent, reasonable, and helpful campaign of education conducted by the State Geological Survey. Obviously so great a saving must have an appreciable effect in checking the rate of decline and in keeping wells flowing that would otherwise have failed by this time or would fail in the near future.

Although the rate of recharge is not definitely known, it probably amounts to a few hundred gallons a minute for each row of townships but not to as much as 1,000 gallons a minute. For the sake of seeing more clearly what will be the beneficial effect of carrying out the recommendations for further reductions made by the State water geologist, let it be assumed that the rate of recharge is equal to the 417 gallons a minute of flow recommended by him. In 1923 this amount of water was being discharged by the 48 strongest wells among the total number of a little more than 330 wells that were inspected. Obviously with this amount of recharge and no further attempt at conservation, most of the available supply will ultimately be discharged by a few of the strongest wells, and a large majority of the wells that are now flowing will either fail entirely or will not yield enough for practical purposes. On the other hand, with this amount of recharge, if all reductions are made as recommended, there will be no further decline and all the existing flowing wells will be saved. The basal assumption may be inaccurate, but 
the principle illustrated by it is sound. It is possible that the recharge is so small or that the underground leakage is so considerable that the ultimate failure of most of the flowing wells can not be prevented even if the program of the State Geological Survey is faithfully carried out, but the conditions are certainly hopef'ul enough to justify a thorough trial of this program. Every owner of a flowing well in this artesian basin should, for his own good and that of his neighbors, give his utmost support to this program for saving the artesian water.

\section{EFFECT OF WASTE IN SOUTH DAKOTA}

The question is often asked whether conservation in North Dakota can be effective without conservation in South Dakota. It is highly desirable that the States should cooperate in this movement. However, the present investigation has shown that the effects of depletion in one area are not rapidly transmitted to other areas. Doubtless wells near the State line in North Dakota will suffer by waste from near-by wells in South Dakota, but this should not deter the State of North Dakota from proceeding with its well-planned program of conservation. Such a program is of course equally desirable in South Dakota.

\section{HEAD OF THE DEEP ARTESIAN WATER}

The entire foregoing discussion of depletion has related to the upper part of what is generally regarded as the Dakota sandstone, in which all except a very few of the artesian wells in this region end and which yields relatively soft but saline water. The deeper artesian stratum, which has been tapped by the 1,385-foot well at Ellendale (p. 80), yields very hard water that is generally regarded as of even poorer quality than the water from the upper strata, although it contains less common salt and is less injurious if used for irrigation.

The striking difference in the chemical character of the water from these two sources is shown by analyses of samples from the two city wells at Ellendale. The water from the 1,087-foot well is reported to have total solids amounting to 2,736 parts per million and that from the 1,385-foot well 1,967 parts per million. The upper water contains only 15 parts of calcium, whereas the lower water contains 204 parts; the upper water contains 1,224 parts of chloride, whereas the lower contains only 70 parts; the upper water contains only 142 parts of the sulphate radicle, whereas the lower contains 1,177 parts. (See p. 74.)

So few 'wells have been drilled into this deeper stratum that in 1923 it still had a strong artesian pressure, more comparable to the pressure in the upper strata in 1902 than to that in 1923. The 
1,385-foot well in Ellendale is reported to have had an original pressure in 1908 of 193 pounds to the square inch, or a head of 1,895 feet above sea level, which is greater than the original head of the first well in 1886. It was also reported to have had an original flow of 800 gallons a minute. In 1923 it still had a strong pressure and flow. The deep well at La Moure was tested in 1923 and was found to have a pressure of 97 pounds to the square inch.

The radical differences in both pressure and chemical composition of the water show that this lower stratum must be separated from the upper strata by an effective and widespread confining bed.

\section{QUALITY OF THE WATER}

The water from the artesian wells that end at the first horizon of the Dakota sandstone is generally usable for all purposes except in the region west of a line from Monango to Grand Rapids, where much of it is too bitter for drinking by man. Water from the second and third horizons contains too much mineral matter for drinking or for boiler use. It is used mostly for fire protection and sewage flushing. The following analyses of artesian and shallow-well waters at Ellendale were supplied by the Electric Light Co. of that town:

Analyses of water from wells at Ellendale, N. Dak.

[Parts per million.a Analyzed by Dearborn Chemical Co., Aug. 12, 1914]

\begin{tabular}{|c|c|c|c|}
\hline & $\begin{array}{c}\text { Artesian } \\
\text { well (flrst } \\
\text { horizon) b }\end{array}$ & $\begin{array}{c}\text { Artesian } \\
\text { well (deep } \\
\text { horizon) }\end{array}$ & $\begin{array}{l}\text { Shallow } \\
\text { well d }\end{array}$ \\
\hline 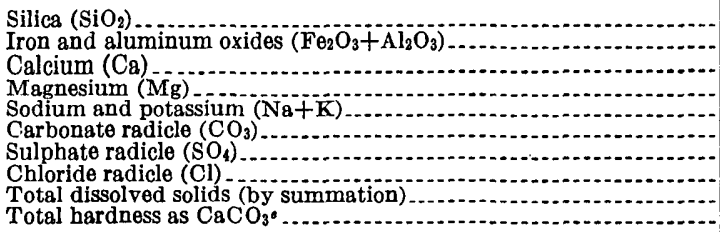 & $\begin{array}{c}5.6 \\
15^{.39} \\
7.0 \\
1,054 \\
288 \\
142 \\
1,224 \\
2,736 \\
66\end{array}$ & $\begin{array}{r}6.4 \\
1.6 \\
204 \\
58 \\
345 \\
105 \\
1,177 \\
70 \\
1,967 \\
748\end{array}$ & $\begin{array}{r}47 \\
3.4 \\
363 \\
338 \\
576 \\
404 \\
2,012 \\
554 \\
4,297 \\
2,290\end{array}$ \\
\hline
\end{tabular}

a Recalculated from hypothetical combinations in grains per U. S. gallon.

- Old city well, 1,087 feet deep, $33 / 4$ inches diameter.

- New city well, 1,385 feet deep, $3 \frac{1}{2} / 2$ inches diameter.

d 20 feet deep.

- Computed.

The waters represented by these analyses contain more dissolved mineral matter than is generally considered desirable.

The artesian water from the first horizon is for most purposes the least objectionable. It is not very hard and is comparatively free from iron, so that it should be satisfactory for laundry work and other household use. Sodium and chloride, the constituents of common salt, make up more than two-thirds of the mineral matter and give a salty taste to the water. The presence of so much salt 
makes it improbable that the water could be used successfully for irrigation.

The artesian water from the deep well is characterized by the large proportion of sulphate and the comparatively large quantity of calcium that it contains, although more sodium than calcium is present. The calcium and magnesium make the water very hard. This hardness decreases its value for domestic and boiler use, but it might be used with success for irrigation on loose, well-drained soil.

The analysis of water from the shallow well indicates that this water is almost too bad for any use affected by the dissolved mineral matter. The main constituents of the water are sulphate, magnesium, and calcium. The magnesium and calcium cause excessive hardness. The water might cause corrosion if used regularly in steam boilers. All three waters may require attention to prevent foaming in boilers.

The following analyses of artesian water from the deep well at Aberdeen, S. Dak., and the well at Westport, S. Dak., which draws from the first horizon, were made by the Department of Chemistry of the State College at Brookings, S. Dak., in 1895, and show the composition of water in the region just south of the EdgeleyLa Moure area :

Partial analyses of water from wells at Aberdeen and Westport, S. Dak.

[Parts per million.a Analyzed in 1895 by Department of Chemistry, State College, Brookings, 8. Dak.]

\begin{tabular}{|c|c|c|c|c|c|}
\hline & $\begin{array}{l}\text { Aber- } \\
\text { deen }\end{array}$ & $\begin{array}{l}\text { West- } \\
\text { port }\end{array}$ & & $\begin{array}{l}\text { Aber- } \\
\text { deen }\end{array}$ & $\begin{array}{l}\text { West. } \\
\text { port }\end{array}$ \\
\hline $\begin{array}{l}\text { Calcium }(\mathrm{Cr}) \\
\text { Magnesium }(\overline{\mathrm{Mg}}) \\
\text { Sodium }(\mathrm{Na}) \\
\text { Carbonate radicle }\left(\mathrm{CO}_{8}\right) \\
\text { Carbon }\end{array}$ & $\begin{array}{r}35 \\
23 \\
635 \\
116\end{array}$ & $\begin{array}{r}8.0 \\
10 \\
966 \\
348\end{array}$ & $\begin{array}{l}\text { Sulphate radicle }\left(\mathrm{SO}_{4}\right) \\
\text { Chloride radicle }(\mathrm{Cl}) \\
\text { Sum of constituents } \\
\text { Total hardness as } \mathrm{CaCO} \mathrm{CO}_{8} \mathrm{~b}\end{array}$ & $\begin{array}{r}1,118 \\
144 \\
2,247 \\
182\end{array}$ & $\begin{array}{r}282 \\
911 \\
2,525 \\
61\end{array}$ \\
\hline
\end{tabular}

- Recalculated from hypothetical combinations in parts per thousand.

- Computed.

From these and hundreds of other analyses it is found that the mineral content of waters of both shallow and deep wells in the region is very high, too high in some waters to permit them to be used regularly for drinking. Some wells yield water that has proved to be positively injurious. On the other hand, most people drink the waters with impunity, especially the salty artesian water. It is a well-known fact that people become accustomed to the artesian water and later find waters containing less mineral matter in solution insipid. Livestock generally refuse artesian water at first, but after becoming accustomed to it prefer it to less highly mineralized water.

Comparison of the analyses of these waters with those of artesian waters given in the previous table shows that the chemical composi$6147-29-6$ 
tion of the waters is similar. The water from Westport is very much like that from the first horizon at Ellendale. The artesian water at Aberdeen resembles that from the deep well at Ellendale in that both are sodium-sulphate waters, but the calcium and magnesium content and therefore the total hardness of the former is very much less than that of the latter.

As the waters at Aberdeen and Westport are thus so similar in composition to those at Ellendale practically the same economic relations hold, and the statements made in the discussion of the waters at Ellendale are doubtless applicable to the entire area covered by this report. Less scale would form in boilers in which the waters at Westport and Aberdeen were used, but such large quantities of sodium and potassium are present in solution that trouble from foaming would be experienced. Neither of these waters is corrosive.

\section{TEMPERATURE OF THE WATER}

One reason for unpalatableness in the artesian water is its high temperature, which ranges from $50^{\circ}$ to $70^{\circ}$. In a region of long cold winters the uniformly warm water proves a great boon for livestock. 'The wells are unaffected by the air temperature, and water flows away from them many rods before freezing. The highest temperatures reported for wells in the Edgeley-La Moure area are $69^{\circ}$ and $70^{\circ}$ at Ellendale and the Taylor farm. Very few temperature records have been kept. The following are available:

Temperature in wells in Edgeley-La Moure area

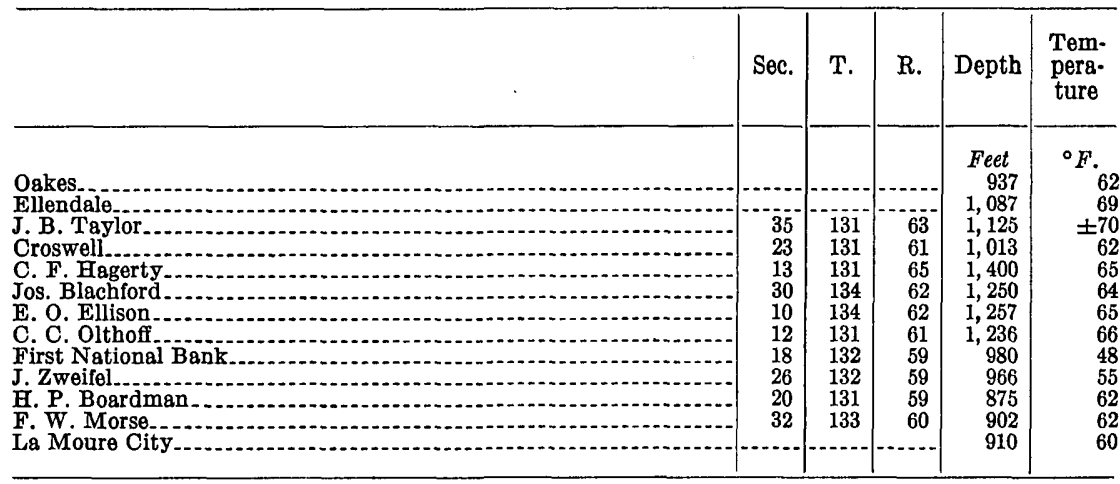

NATURAL GAS

Small flows of natural gas are obtained within the Edgeley and La Moure quadrangles from the artesian wells indicated by special symbols upon the accompanying maps. Here, as in north-central South Dakota, the gas seems to occur as an unsaturated solution under pressure in the artesian waters of the Dakota sandstone and ap- 
parently is released from solution by the reduction of pressure incident to the rise of the water to the surface. As might be expected in view of its mode of occurrence, the gas seems to be distributed areally without reference to minor structural features. It does not have an even regional distribution, being most plentiful in the area east of Edgeley and north of a line connecting Merricourt and Grand Rapids, although it is probable that all wells west of the area of natural flow once emitted gas. It is doubtful if any appreciable amount of the gas originates locally, most of it probably having been taken into solution in areas farther west during the underground flow of the artesian waters. This assumption may possibly account for the general absence of gas in the southeastern part of the area comprising the Edgeley and La Moure quadrangles, as this district may be supplied by waters that come from the eastern catchment areas of the Dakota sandstone rather than from the western.

The gas is largely methane or marsh gas and burns with a hot blue flame, giving excellent results with mantle burners and in ranges. The expense of installing the necessary equipment has deterred a number of persons from availing themselves of their gas supply, but this first cost seemingly might be more than offset by the scarcity and high price of other fuels locally available.

The quantity of natural gas available has never been measured accurately, but the yield of the most productive well probably never exceeded 20,000 cubic feet daily, and the yields have dwindled more or less with the decrease in rate of artesian flow that has prevailed throughout the area. Perhaps 50 wells have yielded volumes of gas sufficient for the domestic needs of single families. The supply afforded by eight wells within the area has been so utilized in the past, but not much is being used now, although 30 to 40 wells are believed still to afford quantities adequate for such use. The only home found equipped so that the gas could be lighted was that of F. B. Peek, sec. 21, Wano Township. Other persons who formerly used the gas are Charles Sturgeon, Miss Libby Soby, and the Electric Light Co., all in Edgeley; R. R. Davis, in sec. 24, Nora Township; A. H. Carrow, in sec. 18, Wano Township, W. J. Pritchard, 1 mile southeast of Edgeley; and the former owner of sec. 31, Russell Township.

Perhaps the first to use the gas was Mr. Sturgeon, who was permitted to tap the water main of the Edgeley town well. His home and store were lighted, his cooking was done, and a heating stove was operated for a few years with the gas so obtained. When a town settling tank was installed this supply was diverted and used by the town electric lighting company until, owing to faulty construction, the tank exploded. This tank has not been replaced. 
In 1906 Miss Soby installed a lighting system in the Northern Hotel, and 15 lights and a heater were maintained for two years. The type of tank used here as elsewhere was a sheet-iron cylinder of about 15 feet dimensions, water-sealed in a wooden-stave tank, which served as container for the water supply. The well pipe conducted the water directly underneath the inner tank, where the gas escaped from the water and was caught. The tank once filled, the surplus gas readily escaped. The top of the tank was sufficiently weighted to produce the pressure requisite for forcing the gas into the house. As nearly as could be ascertained these tanks could be filled several times a day by the more productive wells. A large tank was erected at the Pritchard well, near Edgeley, and gas collected in it was used until the well ceased to yield water.

One of the most complete gas-lighting plants was installed in sec. 24, Nora Township, and used for more than seven years by $R$. R. Davis. The well is $11 / 4$ inches in diameter and 1,280 feet deep, and when drilled it yielded a flow of 29 gallons a minute with 75 pounds pressure. Forty feet of perforated pipe admitted the water at the bottom of the well. The gas was sufficient to fill a cylindrical tank $51 / 2$ by $51 / 2$ feet in two hours, and its pressure lifted a 150-pound weight on the top of the tank. The gas supplied 13 burners day and night, a gas range, and a gas heater. In a stove burning lignite it was found very effective to direct a stream of gas on the burning fuel. A. H. Carrow, in sec. 18, Wano Township, had a similar plant in use for 13 years, supplying six lights and a range. It fell into disuse when Mr. Carrow's first well stopped flowing. The former owner of sec. 31, Russell Township, caught gas in large barrels and used it in a simple way. Another complete gas-using system is that of $\mathbf{M r}$. Peek, who has a 30-gallon tank and has used the gas for about 13 years. Here as elsewhere the blue gas flame shot from a freshly opened water faucet to the ceiling when a match was applied. In a Welsbach burner the flame brought the mantle to dazzling incandescence.

DATA ON ARTESIAN WELLS

The following is a list of the larger wells in the area, with their original pressures and flows: 


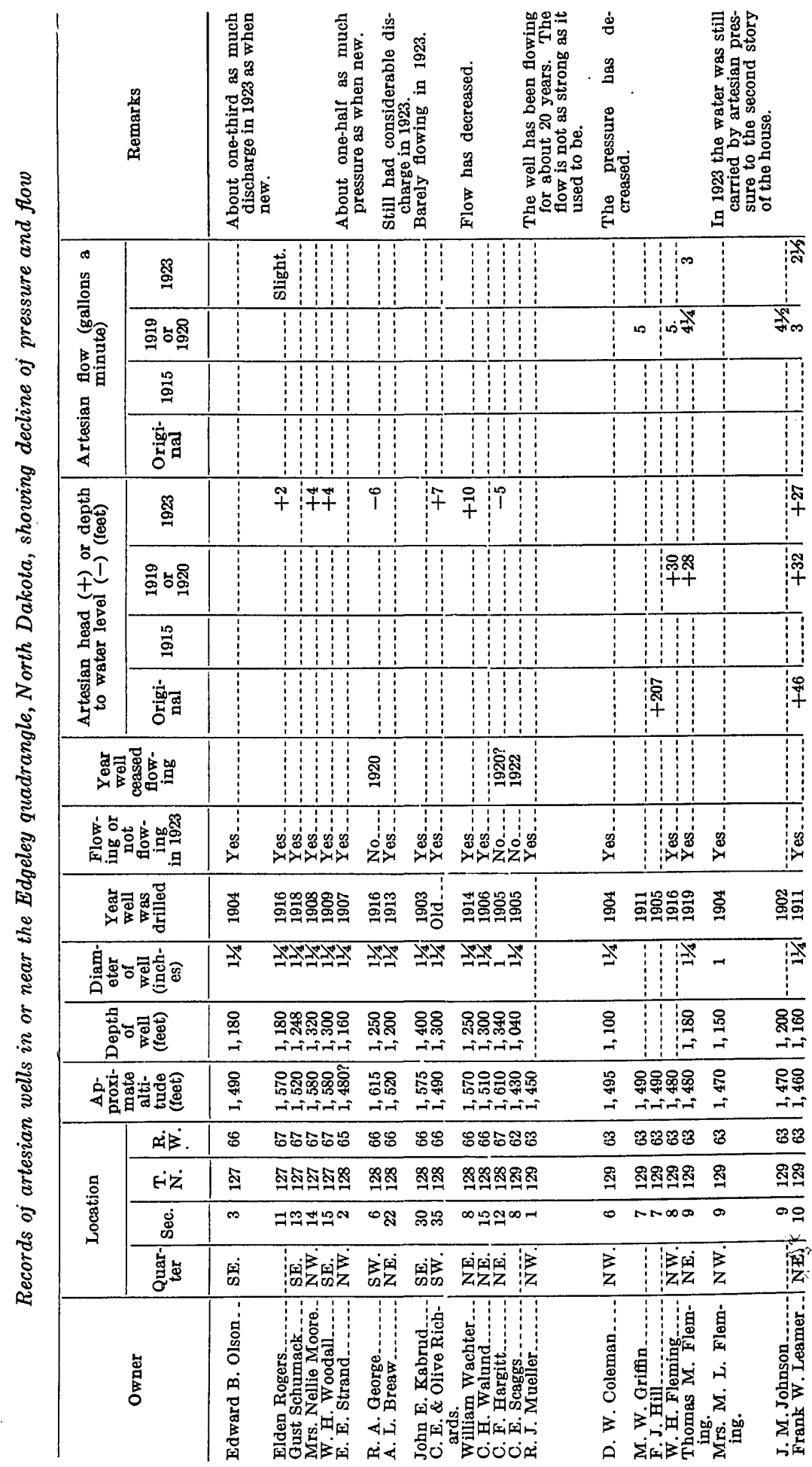




\begin{tabular}{|c|c|c|c|c|c|c|c|}
\hline \multicolumn{2}{|c|}{ ته } & \multicolumn{2}{|c|}{ 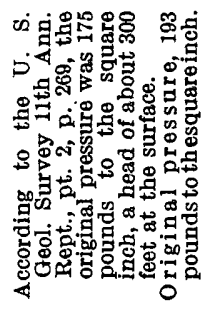 } & 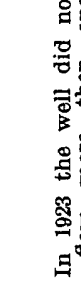 & 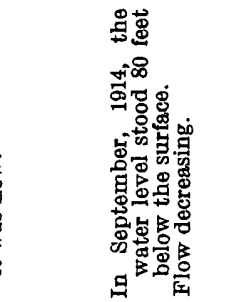 & \multicolumn{2}{|c|}{ 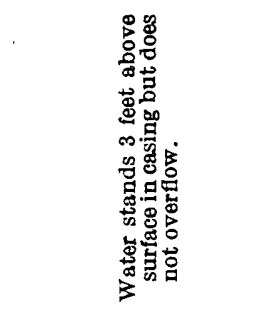 } \\
\hline \multirow{4}{*}{ 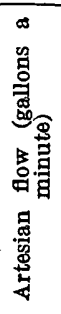 } & హ్లొ & & & & \begin{tabular}{l:l}
$\infty$ \\
\hdashline
\end{tabular} & \begin{tabular}{|l|l|l} 
& & \\
& & Nल्नल \\
& &
\end{tabular} & $\lambda_{e}^{\infty}$ \\
\hline & ఫ్రిం్త్రి & & $\stackrel{\sim}{\sim}$ & $\infty$ & काजि & ๙ & సे \\
\hline & $\stackrel{\mathscr{a}}{\mathrm{g}}$ & & & & & & \\
\hline & 它范 & 용 & 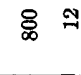 & & \begin{tabular}{l:l}
2 & 10 \\
\hdashline
\end{tabular} & 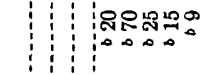 & 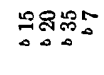 \\
\hline \multirow{4}{*}{ 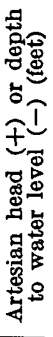 } & జ్ల & & & & & 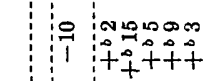 & $\begin{array}{l}m a n c 0 \\
\dot{+}+\dot{+}+\overrightarrow{+}\end{array}$ \\
\hline & 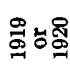 & & & & 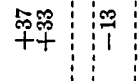 & & \\
\hline & $\stackrel{9}{\leftrightarrows}$ & & & & & & \\
\hline & 㝘至 & & $\stackrel{\mathbb{F}}{+}$ & & 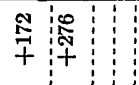 & 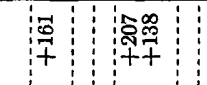 & \\
\hline \multicolumn{2}{|c|}{ 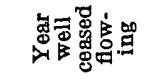 } & & & & & $\begin{array}{l}0 \\
0 \\
0\end{array}$ & \\
\hline \multicolumn{2}{|c|}{ 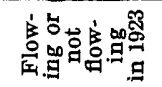 } & $\stackrel{3}{3}$ & $\begin{array}{c}\vdots \\
\vdots \\
y_{0}^{2} \\
\vdots\end{array}$ & 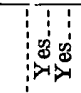 & 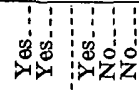 & 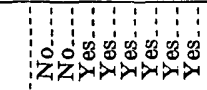 & 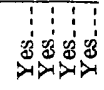 \\
\hline \multicolumn{2}{|c|}{ 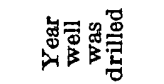 } & $\stackrel{\infty}{\infty}$ & 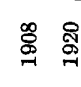 & 음윰욤 & 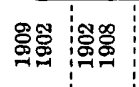 & ㅇ్ㅇ్తి & 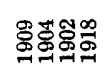 \\
\hline \multicolumn{2}{|c|}{ 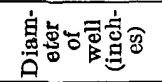 } & बें & సै & - & $\Rightarrow$ & : & $\Rightarrow \approx-A^{2} \approx$ \\
\hline \multicolumn{2}{|c|}{ 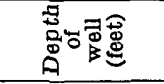 } & $\begin{array}{l}\stackrel{0}{0} \\
-\approx\end{array}$ & $\begin{array}{ll}\infty \\
\stackrel{\infty}{\circ} \\
-\end{array}$ & : & 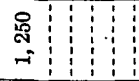 & 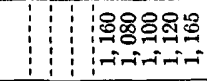 & 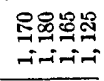 \\
\hline \multicolumn{2}{|c|}{ 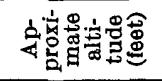 } & 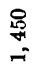 & 委 & 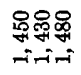 & 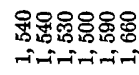 & 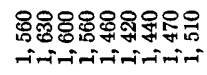 & 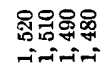 \\
\hline \multirow{4}{*}{ 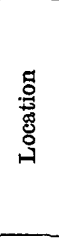 } & $x_{i}$ & 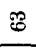 & $ஜ \varnothing$ & ஜ: & 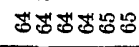 & 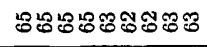 & ஜஜஜஜ \\
\hline & Eं究 & $\stackrel{\mathbb{N}}{\sim}$ & 尽 尽 & స్తిన్సన్సి & 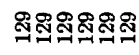 & 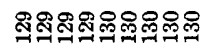 & 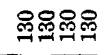 \\
\hline & 飠 & $\cong$ & $\cong \exists$ & సีสజజ & $\operatorname{LnODNN}$ & సేన్లిణ్లో & $\operatorname{org} \theta$ \\
\hline & 密葛 & $\sum_{0}$ & 空谧 & 鼠宙 & 鼠露 & 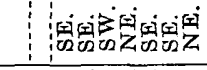 & 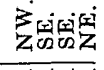 \\
\hline & & 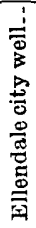 & 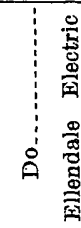 & 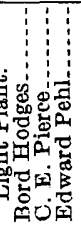 & 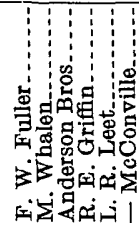 & 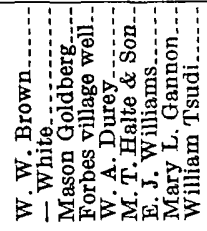 & 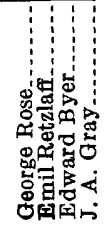 \\
\hline
\end{tabular}




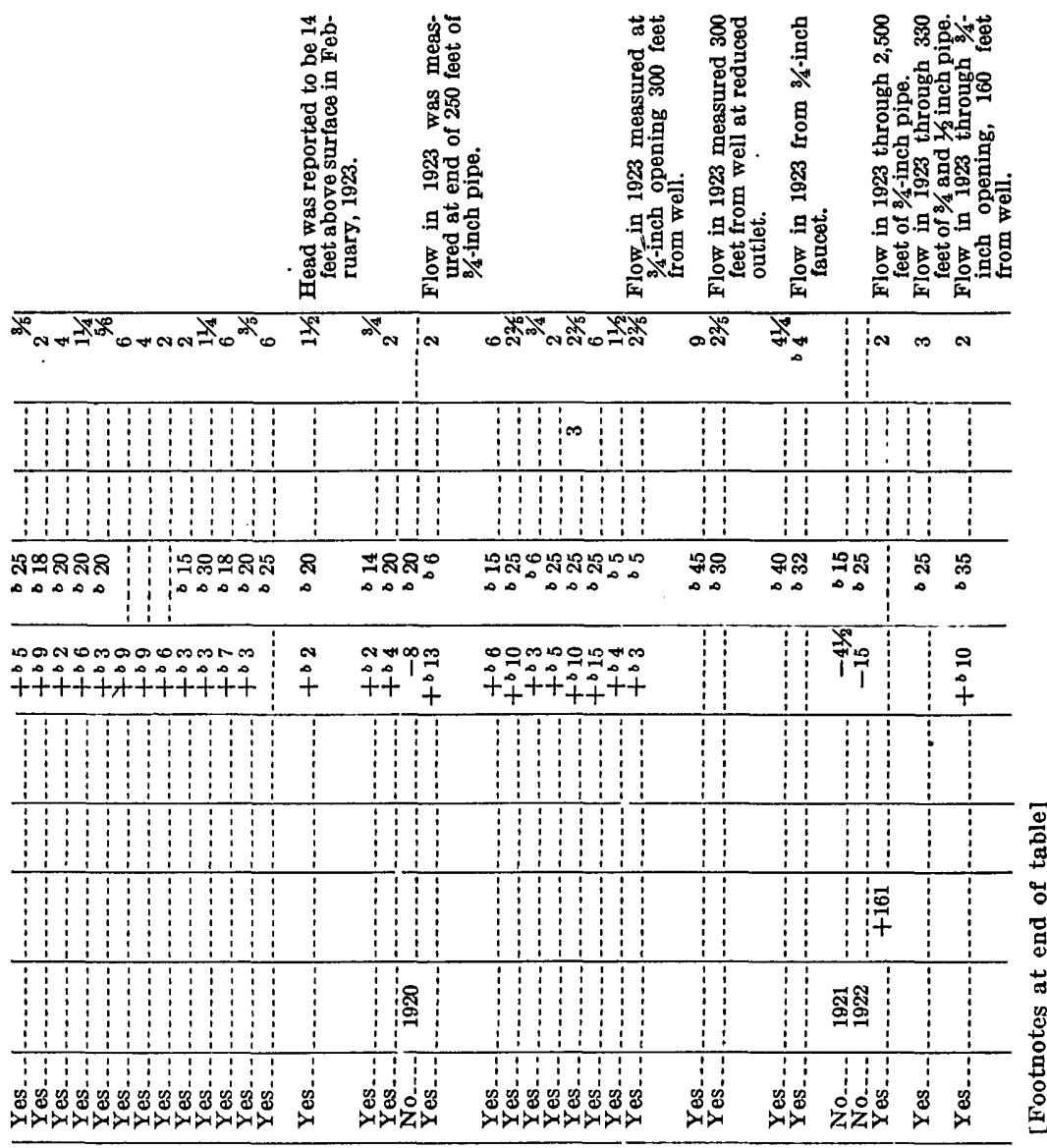

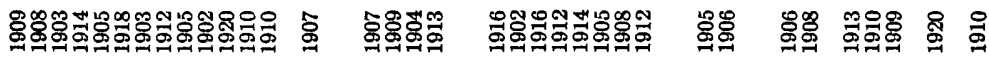

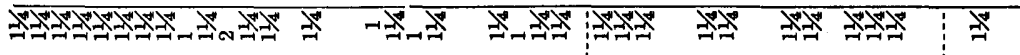

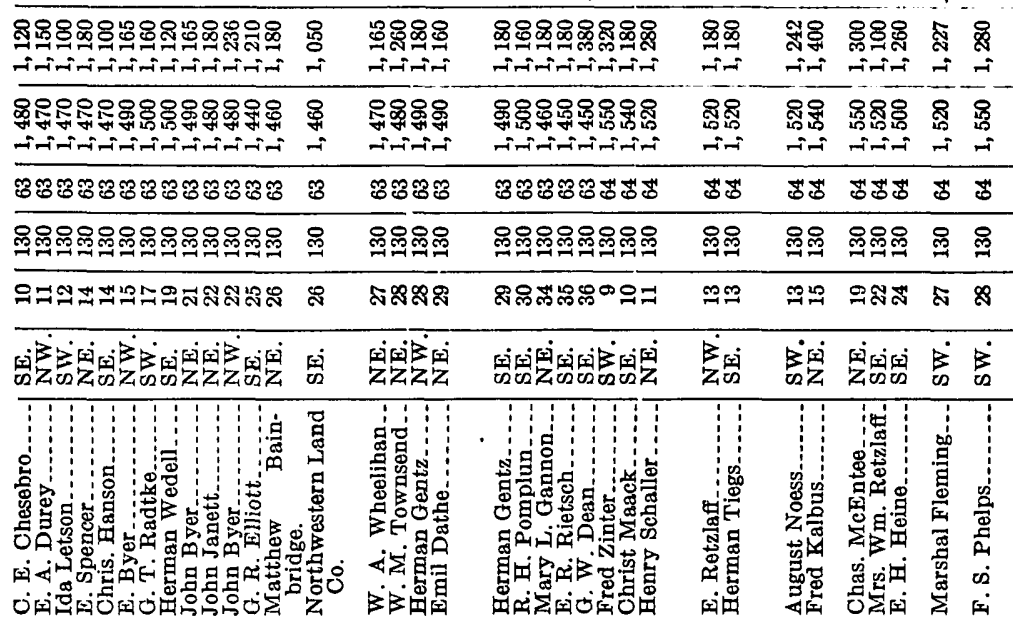




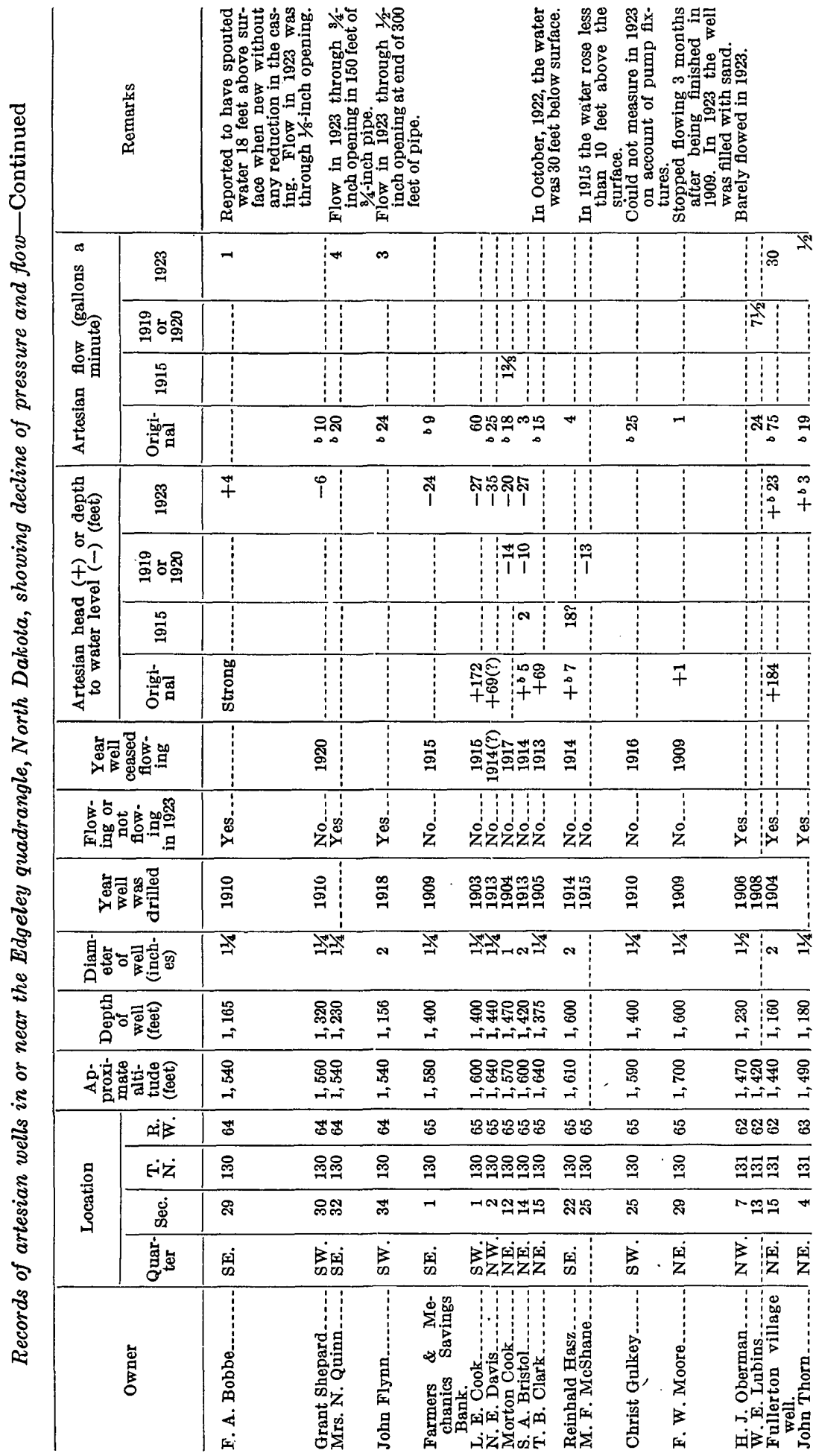



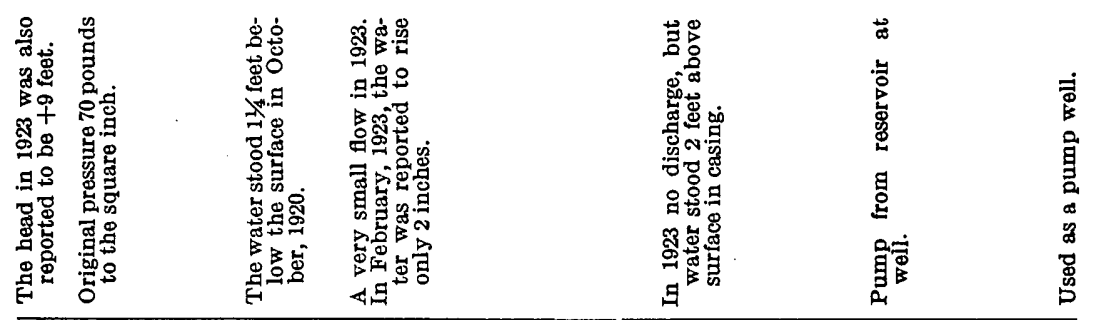

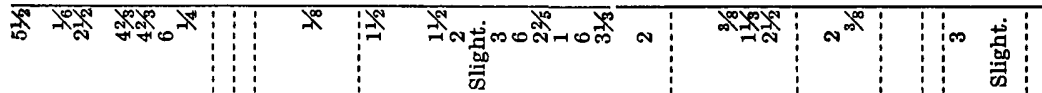

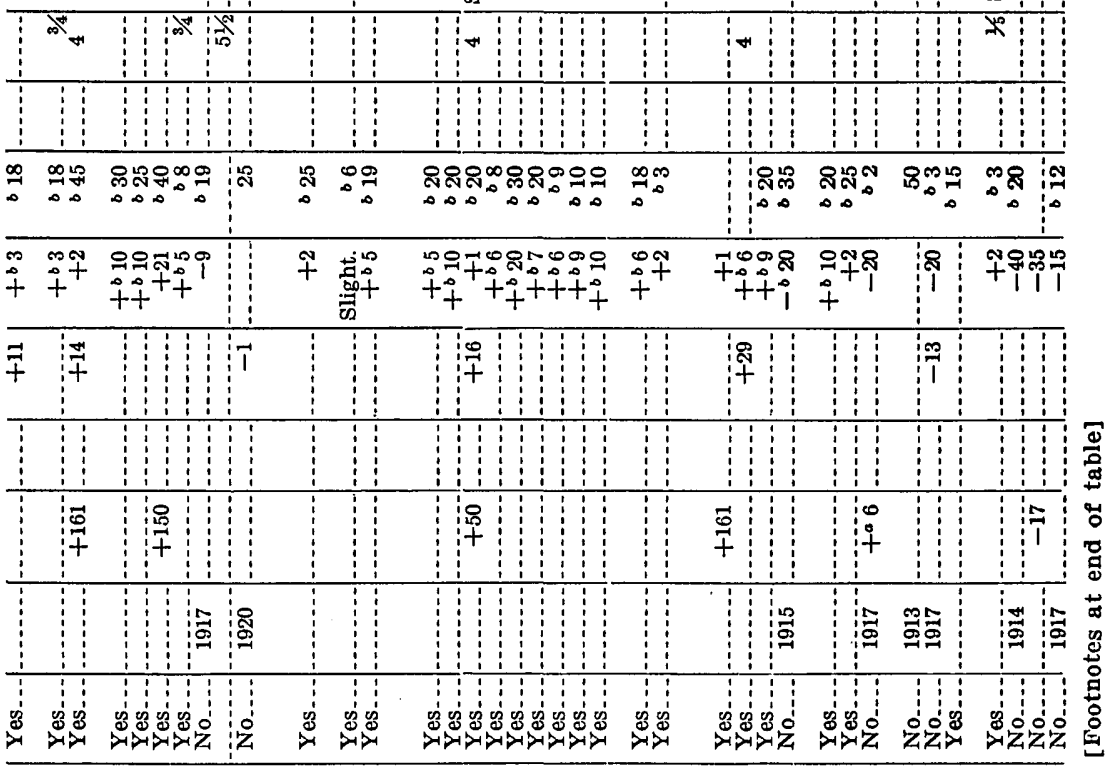

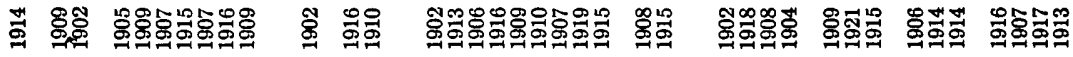

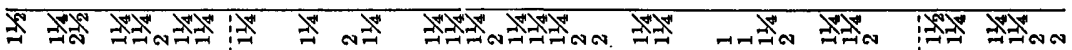

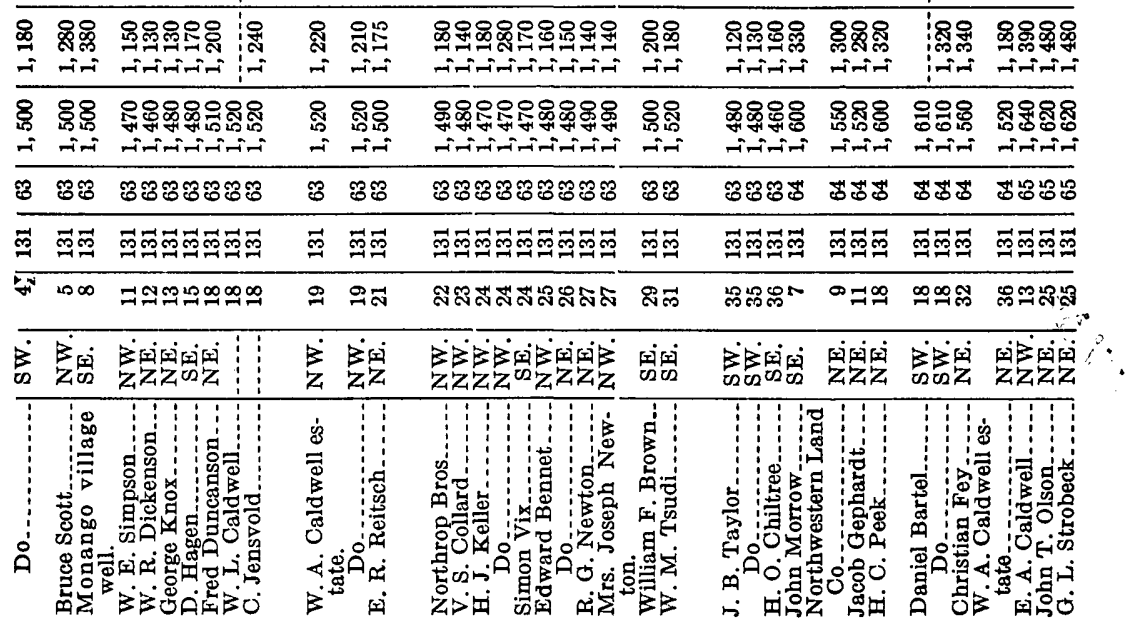




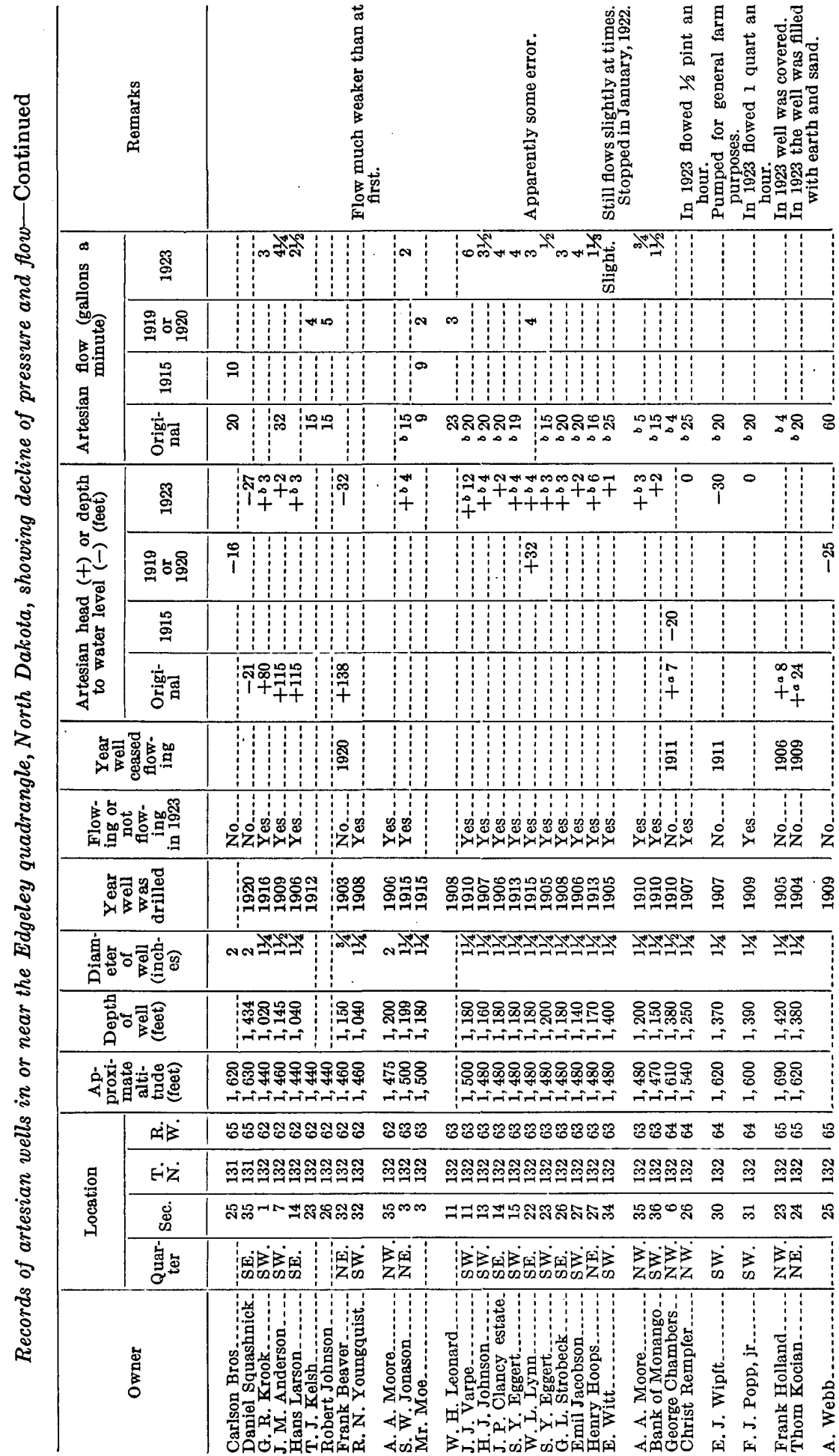




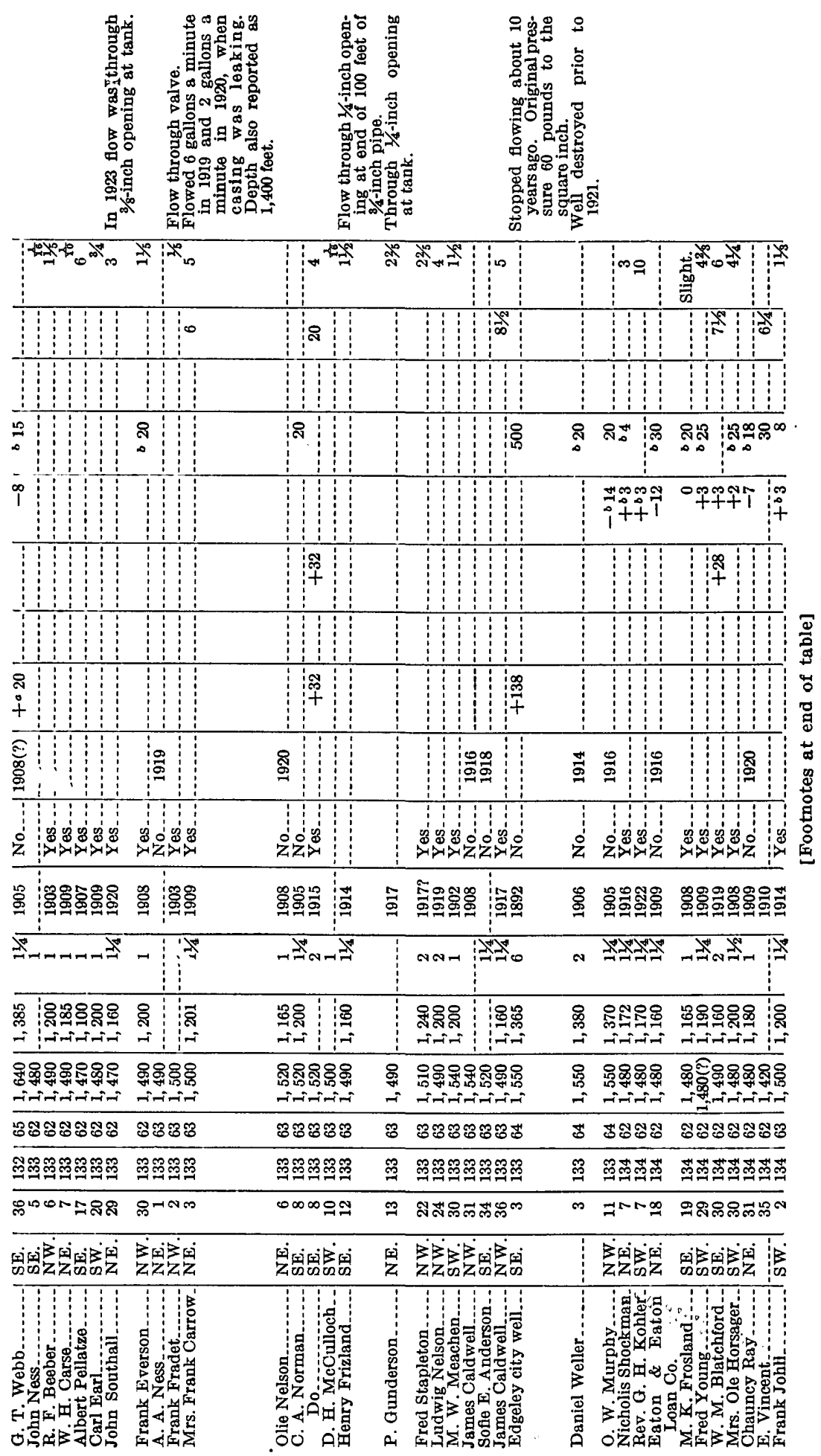




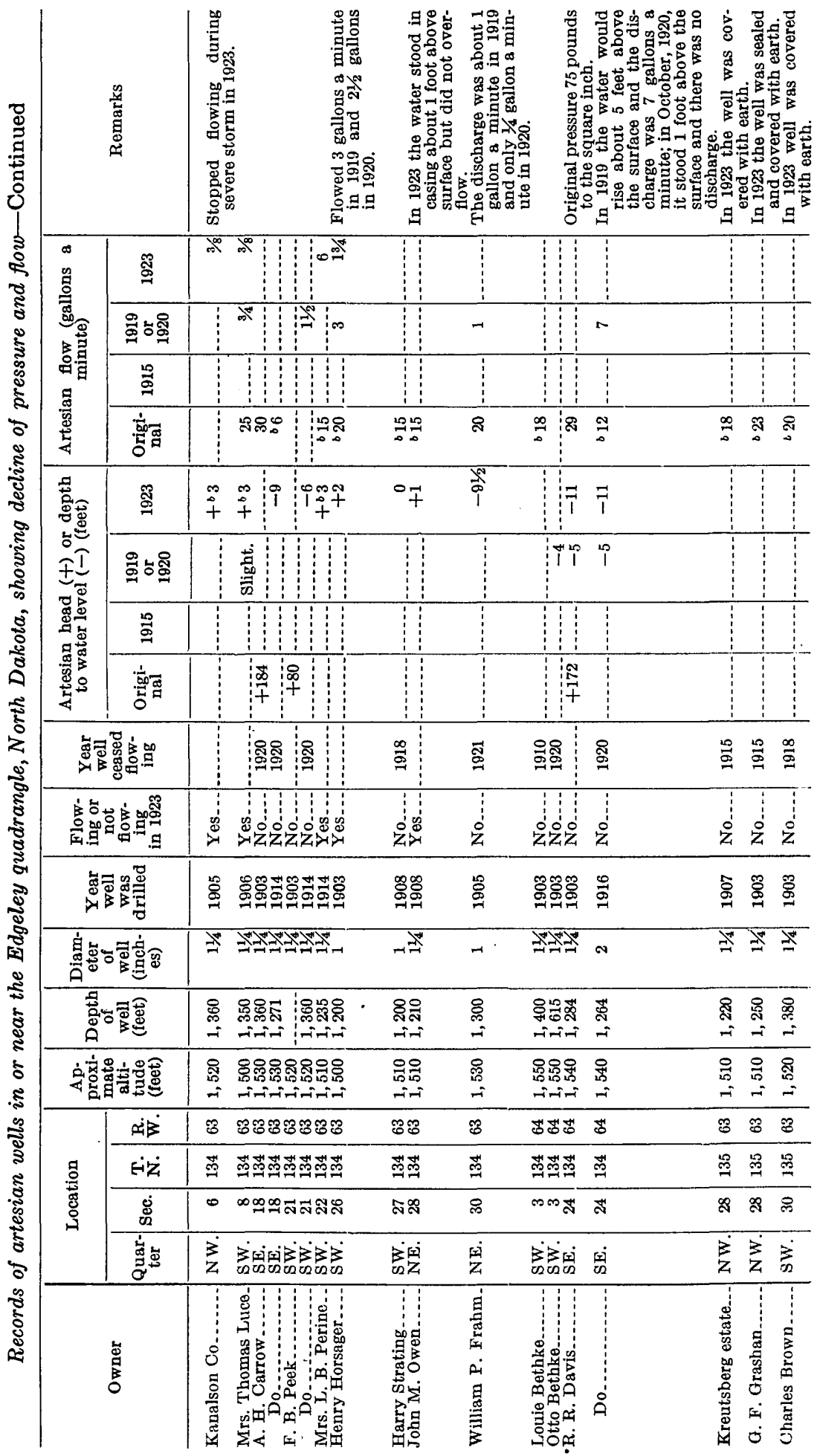




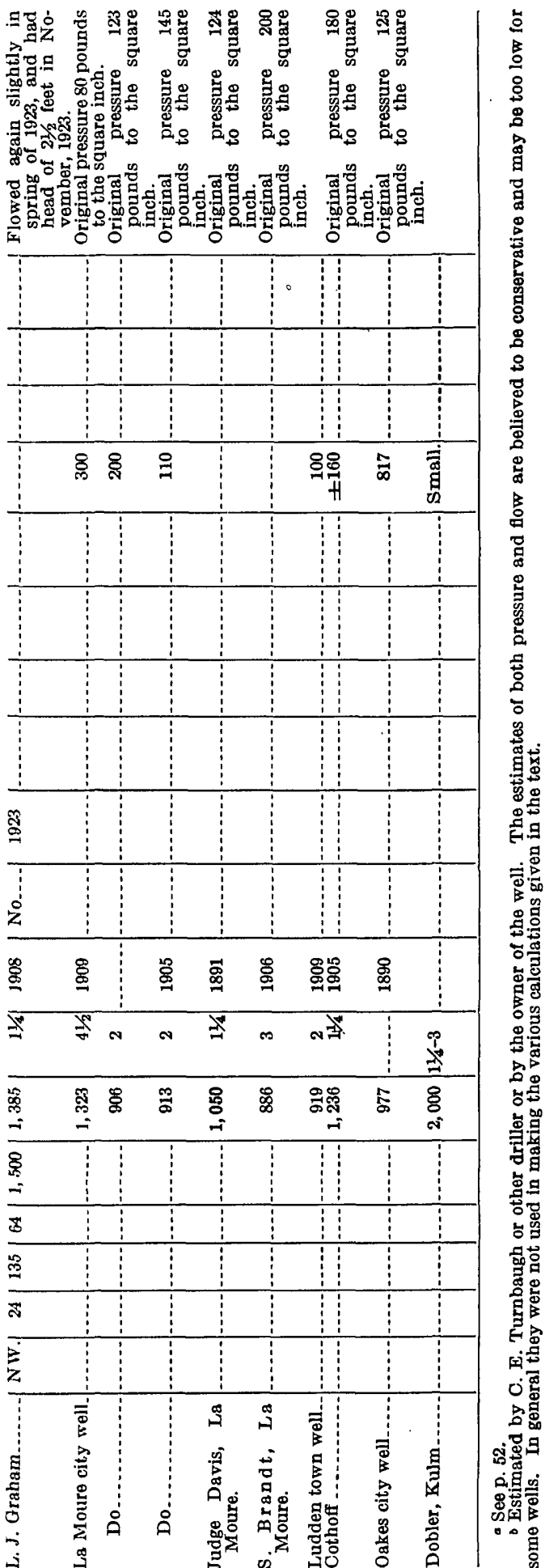





\section{INDEX}

Page

A berdeen, S. Dak., analysis of water from ... $\quad 75$

Acknowledgments for aid.

Alkali, occurrence of.

Altamont moraine, description of........... 25-27

Antelope morsinic system, description of . . . 28-29

till plains adjoining................ 27-28, 29-30

Artesian flow, original head and area of. ... .. 58-59 shrinkage in area of ................... 60-61, 62

Artesian water, depth, head, and quality of. 73-74 natural gas in...................... 76-78

temperature of............... 76

Artesian wells, beneflcial flow of ............ 66

data on..................... 78-87

decline in head of............. 54-56,59-60,62

features and yields of.................. 50-51

flowing, decline in yield of............. 62-63

specific capacities of . . . .............. 63-64

total diseharge of . . . . . . . . . 64-66

history of, in the Edgeley quadrangle. ... 57-59

original head of ................. 53-54

pressure in . ......................... 50, 51-53

quality of water in...

rate of recharge for.............. . . . . 66-67

scope and methods of testing .......... 47-49

Bear Creek, features of ...................... 10

Bedrock, configuration of................... 22-23

Benton shale, nature and thickness of . ..... 15-16 water in....... 45-46

Boulders, glacial, material of........... 21-22

Building materials, deposits of................ 42

Clay, possible uses of........................ 42

Climate of the quadrangles. ................ 12-13

Color of the till. ............................ 20

Colorado group, formations of . . . . . . . . 15-17

Coteau des Prairies, features of . ............. 3

Coteau du Missouri, description of . . . 22-23, 26, 27

terminal moraine on, plate showing...... 26

Cretaceous formations, presence and features of .

Cretaceous period, events of . . . 2 . 35-36

Dakota epoch, events of 35-36

Dakota sandstone, compression of, from withdrawal of stored water .......... 67-71

nature and thickness of ................. 14-15

water in .............. 47-56

Drainage, preglacial, of the Dakotas, probable course of ................... 37-38

Drainage of the quadrangles.............. 8-11

Drift, age of . ............................... 20-21

surface form of .................. 22

thickness and composition of . . . . . . 18-20

water in
Edgeley, N. Dak., analyses of water from.... 45

Edgeley quadrangle, map of, showing areal geology ........................... map of, showing thickness of glacial drift and artesian-water conditions...

In pocket.

Ellendale, N. Dak., analyses of water from.- 74

Elm River, features of ...................... 11

Erosion, post-Cretaceous, results of .......... 36-37

Gary moraine, description of . ............... 25-27

till plain east of .......................... 27-28

Glaciation, history and effects of........ 6-8, 38-40

Gravel, economic deposits of................. 42

Hydraulic gradient, increase in.............. 61

James River, description of ...................

terraces of ................................. 33-34

James River valley, description of ............7, 9-10

early events in............................. 41-42

Jamestown quadrangle, limit of artesion flow

in

Lake Dakota, glacial, deposits of . ............ 33, 41

glacial, floor of........................... 7

origin of ................................ 40-41

Lakes of the quadrangles...................... 11

La Moure quadrangle, map of, showing areal geology....................... In pocket.

map of, showing thickness of glacial drift and artesian-water conditions............................ In pocket.

Location of the quadrangles.................. 1-2

Maple River, description of.................... 10-11

Meinzer, O. E., Artesian conditions and prospects as shown by the survey

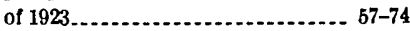

Merricourt Valley, slope of .................. 8

Moraines, correlation of....................... 30-31

plates showing............................. 26

Natural gas, occurrence and utilization of.... 76-78

Nettleton, E. S., quoted ...................... 69

Niobrara shale, nature and thickness of...... 16-17 water in ................................... 45-46

North Dakota, bedrock surface in........... 4 conservation of artesisn water by........ 71-73

drainage of .............................. 3

preglacial .............................. 37-38

stratigraphy and structure of ........... 4-5

topography of ............

Oakes moraine, description of................ 31-32 locetion of $\ldots . . . \ldots \ldots \ldots$

plate showing . .......................... 26 
Peat, deposits of........................ 34-35

Pierre shale, nature and thickness of water in

Plains of the quadrangles. 45-46

Pleistocene epoch, events of $38-42$

Quaternary period, events of $38-42$

Relief of the quadrangles. 6-8

Sand, economic deposits of

Sand dunes, occurrence of

Sand Prairie deposits, features of

Settlement of the quadrangles.

Soils of the quadrangles.

South Dakota, effect of waste of water in...

Springs of the quadrangles.
Tertiary period, events of

Pago

Upham, Warren, quoted..................... 30-31

Uplands of the quadrangles............... $7-8$

Vegetation in the quadrangles................ 13

Water, analyses of............................ 45 occurrence of, in glacial drift.............. 44-45 in the Pierre and Benton formations. 45-46 Water-bearing beds, position of .............. 49, 51 Wells, kinds used.............................. 44-45 Westport, S. Dak., analysis of water from... $\quad 75$ Whitestone Hill, battle of .................. 5

Wisconsin drift, description of .............. 23-33 